\title{
APOYO SOCIAL PERCIBIDO EN PACIENTES CON CÁNCER
}

\author{
Tesis Doctoral
}

\section{Gemma Costa Requena}

\section{Dirigida por Dr. Rafael Ballester Arnal}

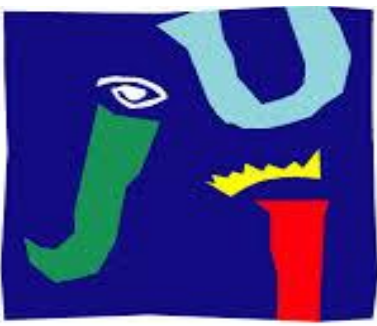

UNIVERSITAT

JAUME• !

\author{
Castellón
}

Diciembre 2014 


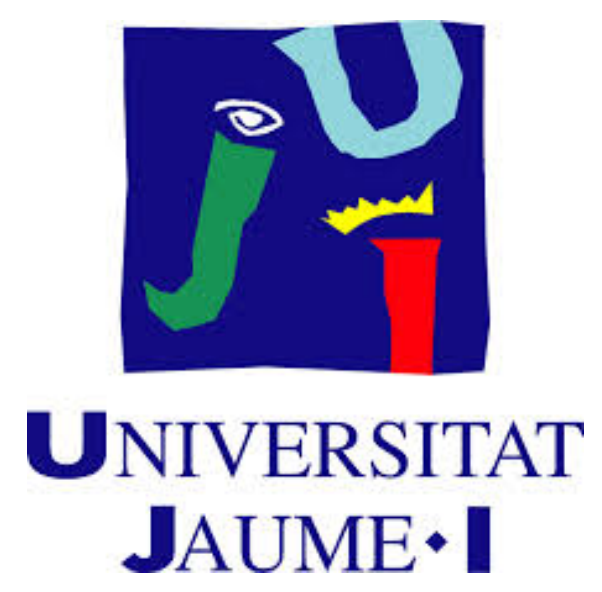

\title{
APOYO SOCIAL PERCIBIDO EN PACIENTES CON CÁNCER
}

\author{
Tesis doctoral presentada por: \\ Gemma Costa Requena
}

Departamento de Psicología Básica, Clínica y Psicobiología Facultad de Ciencias de la Salud

\author{
Director: \\ Dr. Rafael Ballester Arnal
}

Castellón

Diciembre 2014 

A mis padres 

Todo pasa y todo queda Pero lo nuestro es pasar Pasar haciendo caminos Caminos sobre la mar

Nunca persegui la gloria Ni dejar en la memoria De los hombres mi canción Yo amo los mundos sutiles Ingrávidos y gentiles

Como pompas de jabón

Me gusta verlos pintarse de sol y grana

Volar bajo el cielo azul

Temblar súbitamente y quebrarse

Nunca persegui la gloria

Caminante son tus huellas el camino y nada más

Caminante, no bay camino se hace camino al andar

Al andar se bace camino

$Y$ al volver la vista atrás

Se ve la senda que nunca

Se ha de volver a pisar

Caminante no hay camino sino estelas en la mar

Hace algún tiempo en ese lugar

Donde boy los bosques se visten de espinos

Se oyó la voz. de un poeta gritar

Caminante no bay camino, se hace camino al andar

Golpe a golpe, verso a verso

Murió el poeta lejos del hogar

Le cubre el polvo de un país vecino

Al alejarse, le vieron llorar

"Caminante, no hay camino, se hace camino al andar"

Golpe a golpe, verso a verso

Cuando el jilguero no puede cantar

Cuando el poeta es un peregrino

Cuando de nada nos sirve rezar

Caminante no bay camino, se hace camino al andar

Golpe a golpe, verso a verso

Antonio Machado 


\section{AGRADECIMIENTOS}

Me gustaría agradecer a mi director de tesis Dr. Rafa Ballester, la confianza que puso desde el principio en mi propuesta de trabajo, de esto hace ya unos años, creo que rondaba el 2007. Gracias a su ayuda y siempre cálido acogimiento, supe afianzar esta tesis y poner rumbo con puerto de llegada. También agradezco al Dr. Francisco Gil, el haberme introducido en el campo de la psico-oncología y haberme permitido trabajar en el proyecto que propició el trabajo de campo de este estudio.

Gracias a todos los pacientes que han compartido conmigo sus vivencias sobre la enfermedad, y sin los que este trabajo no tendría sentido. A ellos dedico mucho del esfuerzo que hay detrás de este estudio.

Además, en este camino no he estado sola, he recibo el constante aliento y apoyo de mi familia. Doy gracias a mis padres, Tomas y Fina, ejemplo de persistencia y ahínco ante adversidades por el profundo amor que se tienen, y que nos han trasmitido a mis hermanos y a mí. Gracias a mis hermanos, Jose y Tomás, por su constante ayuda y a quienes siempre me he sentido unida, a ellos debo mucho de lo que soy. Agradezco a sus esposas, Queca y Cecilia su apoyo. A las personas que estuvieron, mi abuela Hortensia y mi abuelo Antonio con quienes crecí, mi abuelo Pascual de quien algo caracterial tengo, y mi centenaria abuela Josefa.

Todos los nombres que son más que eso, porque forman parte de mi vida, mis sobrinos, tíos y primos. A mis sobrinos Pepito, Marcos, Quequita, Toni, Tomas, Vicente, Laia, Aina, Covadonga y Antonio. Mis tíos, Antonio y Luisa, Hortensia y Vicente, Estrella, Luisa, Paco. Mis primos Vicente, Estrella, Inés, Noemi, Estrella, Toni, Luis, Consuelo, Jose Vicente. Gracias Antonio, por tu amistad. 



\section{ÍNDICE}

Agradecimientos..................................................

Presentación....................................................... 1

Resumen......................................................... 5

Abstract.......................................................... 7

1.- Introducción................................................ 9

1.1.- Modelo biopsicosocial y Psicología de la Salud................. 12

1.2.- Modelo biopsicosocial y los inicios de la Psico-oncología........ 16

1.3.- Apoyo social, calidad de vida relacionada con la salud y trastorno psicológico en pacientes con cáncer........................ 19

2.-Justificacion de los estudios ................................. 27

2.1.- Apoyo social percibido: conceptualización y dimensiones........ 29

2.2.- Cáncer y apoyo social percibido............................ 34

3.- Hipótesis y Objetivos........................................ 39

3.1.- Hipótesis................................................... 40

3.2.- Objetivos.............................................. 42

4.- Método y Resultados........................................... 44

4.1.- Artículo 1: "The influence of coping response and healthrelatedquality of life on perceived social support during cancer treatment.”. 
4.2.- Artículo 2: "Perceived Social Support in Spanish Cancer

Outpatients with Psychiatric Disorder.”

4.3.- Artículo 3: “A 1-Year follow-up of post-traumatic Stress

Disorder (PTSD) Symptoms and Perceived Social Support in

Cancer."

5.- Discusión

5.1.- Discusión Artículo 1

5.2.- Discusión Artículo 2

5.3.- Discusión Artículo 3

5.4.- Discusión General

5.5.- Limitaciones.

6.- Conclusiones.

7.- Referencias Bibliográficas....

8. Anexos

8.1.1.- Comunicaciones orales a congresos.

8.1.2.- Comunicaciones a congresos formato póster 160

8.1.3.-Relacion de publicaciones derivadas de la tesis. 160

8.2.- Artículos formato de publicación. 164

8.2.1.- Artículo 1 164

8.2.2.- Artículo 2

8.2.3.- Artículo 3 



\section{PRESENTACIÓN}

Actualmente se ha evidenciado un aumento de la incidencia del cáncer, pero asimismo las mejoras en el tratamiento médico han permitido incrementar las tasas de supervivencia del paciente oncológico. El trabajo multidisciplinar, de oncólogos, radio-oncólogos, cirujanos, patólogos, epidemiólogos, biólogos moleculares,..., hoy en día queda orientado a un objetivo en común, manejar y enfrentarse a esta enfermedad en beneficio del paciente. Las pautas terapéuticas actuales con menos efectos secundarios o menos toxicas, nuevos fármacos y tratamientos complementarios que reducen de forma considerable las recaídas después de una cirugía, además de la posibilidad de tratar al paciente en tercera, cuarta y quinta línea de tratamiento, los adelantos en técnicas de la imagen, o gracias al uso de la informática que aumenta la exactitud de la radioterapia y la cirugía, se consigue un incremento de la eficacia de los tratamientos oncológicos. Estas mejoras del tratamiento permiten mayores posibilidades de curación de los pacientes con cáncer, o que el paciente conviva con la enfermedad metastásica con una buena calidad de vida, y así 
llegar a convivir con el cáncer como si se tratara de una enfermedad crónica. De tal forma, que el paciente durante el tratamiento oncológico puede mantener cierta autonomía y funcionalidad dentro de la normalidad en las actividades cotidianas, con una menor afectación del bienestar emocional, y del funcionamiento social o de las relaciones interpersonales. Una parte complementaria en este objetivo, además, es facilitar la implicación de la persona, en llevar hábitos de vida saludables, y conductas de prevención para detectar a tiempo la enfermedad o posibles recidivas que pudiera haber a lo largo de la vida. De los aspectos mencionados, uno de los recursos favorecedores de la adaptación del paciente a su enfermedad, y que ofrece mejoras en la calidad de vida relacionada con la salud es la percepción de apoyo social, y por ello dedicamos el presente trabajo a su estudio.

Efectivamente, en este trabajo de tesis doctoral se reúne la labor de investigación desarrollada como psicóloga clínica, en una beca de investigación disfrutada durante los años 2006 al 2008 en la unidad de Psico-Oncologia del Hospital Duran i Reynals de Barcelona, hospital monográfico de cáncer. Ayudaron a la reflexión de los datos recogidos en pacientes oncológicos, los conocimientos obtenidos a través del trabajo 
asistencial con pacientes con enfermedad avanzada y de mal pronóstico, realizado en la unidad de cuidados paliativos del Hospital St. Jaume i Sta. Magdalena, en Mataró, Barcelona, durante el período del 2006 al 2011, así como la atención psicológica que se ha realizado desde el 2012 en el programa de interconsulta hospitalaria, del Servei de Psiquiatría del Hospital Universitari Vall d'Hebron, Barcelona.

A modo de presentación, se describe el guión de los contenidos de esta tesis, que comienza en un primer apartado con la Introducción general (Capítulo 1), siendo una justificación teórica de la utilización del modelo biopsicosocial como modelo o paradigma del trabajo en psico-oncología, resaltando el papel modulador del apoyo social percibido en la respuesta adaptativa al cáncer, y su influencia en el bienestar físico y emocional del paciente oncológico. En el segundo apartado, se afina en la orientación teórica de los estudios, a partir de la cual se formularon las hipótesis de trabajo (Capítulo 2). Nos acercamos después, al planteamiento de las hipótesis y definición de los objetivos de los estudios (Capítulo 3). En el apartado Métodos y Resultados (Capítulo 4), se presentan los tres artículos publicados en revistas científicas con proceso de revisión externa. En la Discusión (Capítulo 5) se expresa el trabajo de reflexión acerca de los resultados obtenidos, así como su aplicabilidad en el ámbito clínico y de 
investigación. En el capítulo de Conclusiones (Capítulo 6) se resume la corroboración de las hipótesis y la consecución de los objetivos. Finalmente, se presentan las Referencias bibliografías (Capítulo 7) que soportan la introducción general y discusión de este trabajo, y en el Anexo (Capítulo 8) se mencionan las publicaciones científicas realizadas paralelamente por la doctoranda a partir de los datos recogidos en la beca de investigación, y que sirvieron para fraguar su trabajo de tesis. 


\section{RESUMEN}

Desde los inicios de la psico-oncología se propone un acercamiento holístico e integral para el tratamiento del cáncer, que se propicia desde el modelo bio-psico-social. La teoría del buffering-stress, entiende el apoyo social percibido como un amortiguador de eventos estresantes en aspectos relacionados con la salud-enfermedad. Además el apoyo social aporta efectos beneficiosos para el bienestar físico y emocional del paciente. El presente trabajo está formado por tres estudios. Aunque investigaciones previas hacen referencia a la influencia de la percepción de apoyo social sobre la calidad de vida relacionada con la salud, en nuestro primer estudio, en cambio, se estudia como la calidad de vida relacionada con la salud, y en particular la dimensión mental del concepto, afecta a la percepción de apoyo social, y respuesta adaptativa a la enfermedad. Así mismo, el segundo estudio señala que la presencia de un trastorno psiquiátrico interfiere en la percepción de apoyo social, tanto en el índice global de 
apoyo social, como en sus dimensiones funcionales de apoyo emocional/ informacional, y percepción de apoyo afectivo. En el tercer estudio realizamos una evaluación longitudinal sobre uno de los trastornos psiquiátricos que causa intenso malestar emocional en pacientes con cáncer, esto es, los síntomas de estrés post-traumático, su prevalencia y la manifestación de síntomas durante el curso del tratamiento también aparece relacionada con la percepción del apoyo social, con afectación diferencial de síntomas según el momento del tratamiento oncológico. Todo ello, nos advierte de la utilidad que puedan tener las intervenciones psicológicas tempranas para fomentar la percepción del apoyo social en pacientes con cáncer, de esta manera aportar bienestar en aspectos emocionales y físicos relacionados con la calidad de vida del paciente. 


\section{ABSTRACT}

From the beginnings of psycho-oncology a holistic and integrated approach to cancer treatment has been proposed. This is leveraged from the biopsycho-social model. The stress-buffering theory, understand perceived social support as a buffer against stressful events on issues related to health and illness. Moreover, social support provides to the patient beneficial effects on physical and emotional well-being. This research consisted of three studies. Previous studies highlighted the influence of perceived social support on health related quality of life. However, in our first study the influence of quality of life related to health was investigate, particularly, the mental domain of the concept, such as a decisive factor on the perceived social support and adjustment response to cancer. Similarly, the second study showed that the prevalence of psychiatric disorder in cancer patients interfere the perceived social support in the overall index of social support. The prevalence of psychiatric disorder also affects two functional dimensions such as the perceived emotional/informational support and the 
perceived emotional support. The third study was focused on the longitudinal assessment about one of the psychiatric disorder. This disorder cause severe psychological distress in cancer patients, that is, symptoms of post-traumatic stress disorder. The third study analyzed the prevalence of psychiatric disorder during the course of treatment that also appears related to perceived social support. These results showed differential affectation of symptoms depending on the time point of cancer treatment. These results highlighted the necessity of early psychological interventions to promote the perceived social support in cancer patients, to improve emotional and physical well-being related to patients’ quality of life. 


\section{1.- INTRODUCCIÓN}


Según la Organización Mundial de la Salud (OMS) el no tratamiento adecuado de las enfermedades crónicas, tiene efectos adversos en la calidad de vida de las personas afectadas, es causa de muertes prematuras, además de tener un impacto económico desfavorable y subestimado en las familias, las comunidades y la sociedad en general. Se calcula que de las enfermedades crónicas, principalmente las enfermedades cardiovasculares, diabetes, cáncer, y enfermedades respiratorias crónicas causaron el 60\% del total mundial de defunciones en 2005. Además se prevé que en los próximos 10 años el total de defunciones por estas enfermedades aumente otro 17\% (OMS, 2008). En este sentido, y a nivel mundial, el cáncer es una de las principales causas de muerte, que en el 2012 causó 8,2 millones de defunciones en todo el mundo (Ferlay, 2013). Según las publicaciones del Instituto Nacional de Estadística, el cáncer en España fue la segunda causa de muerte responsable del $27,5 \%$ de defunciones. La primera causa de muerte son las enfermedades del sistema circulatorio (30,3\%), y la tercera, las enfermedades del sistema respiratorio $(11,7 \%)$.

Respecto al cáncer, en los datos presentados a finales del 2013, del estudio Globocan-2012 elaborado por la Agencia Internacional para la Investigación en Cáncer, que es el organismo especializado para el cáncer 
de la OMS, se prevé que los casos anuales de cáncer aumentarán de 14 millones en 2012 a 22 millones en las próximas dos décadas. En España la incidencia del cáncer muestra una tasa estandarizada por edad de 215,5 casos por 100.000 habitantes por año, y un riesgo de presentar cáncer antes de los 75 años del 25,1\%. Según este estudio en el 2012 se diagnosticaron en España 215.534 tumores y, se calcula que en 2015 se pueden alcanzar los 227.076 diagnósticos (Ferlay, 2013). Según estos datos, en el 2012 en España, el cáncer con una mayor incidencia es el colorrectal (15\%), el que produce una más alta mortalidad es el cáncer de pulmón (20,6\%), y el que tiene una prevalencia a 5 años más alta es el cáncer de mama (17,9\%) (Ferlay, 2013). Por otra parte es cierto que España se encuentra en la media de los países de la Unión Europea donde se ha producido un descenso en las tasas de mortalidad por cáncer entre 1990 y 2011, con una reducción del 13\% en la tasa de mortalidad; además se considera que un tercio de todos los cánceres tienen actualmente una supervivencia a cinco años por encima del 80\% (SEOM, 2014). El avance en el diagnostico precoz del cáncer y mejoría en el tratamiento, ayuda a disminuir la mortalidad por esta enfermedad.

Gracias a las mejoras en el tratamiento médico y el incremento de las tasas de supervivencia al cáncer, la calidad de vida sostenida del paciente 
con cáncer pasa a desempeñar un papel central. Y en este sentido desde el campo de la psicología se pueden aportar estrategias que favorezcan las mejoras de la calidad de vida del paciente oncológico, como se constata desde los inicios de la psico-oncología (Costa-Requena \& Ballester Arnal, 2011; Holland, 2002).

En nuestro trabajo se resalta el estudio de una variable psicosocial cuyo impacto en la calidad de vida podría ser fundamental, el apoyo social percibido, que desde diferentes ámbitos, la familia, amigos y profesionales sanitarios se proporciona al paciente con cáncer. El objetivo general del estudio será analizar cómo la influencia del apoyo social percibido durante el tratamiento oncológico, o seguimiento a un año, puede aportar mejoras en el bienestar físico y emocional del paciente oncológico, y profundizar en algunos aspectos que lo relacionen con la respuesta emocional adaptativa al cáncer.

1.1.- Modelo biopsicosocial y Psicología de la Salud

Durante el siglo XIX en el que se asumía una concepción dualista salud-enfermedad, desde el modelo biomédico tradicional, las 
enfermedades se podían explicar a partir de problemas en procesos fisiológicos, desequilibrios químicos, e infecciones bacterianas o víricas (Engel, 1977). A lo largo del siglo XX, las mejoras en los tratamientos médicos gracias a los avances farmacológicos y quirúrgicos del momento, la especialización médica en sistemas u órganos corporales concretos, y las mejoras en salud pública y nutrición, cambiaron el panorama epidemiológico con un descenso de enfermedades infecciosas (sarampión, poliomielitis,...), y un incremento de aquellas que desde el punto de vista etiológico y evolutivo estaban relacionadas con el comportamiento y estilos de vida, como el cáncer, enfermedades coronarias, el abuso de drogas y alcohol, o accidentes de tráfico, consideradas como enfermedades crónicas no infecciosas (Matarazzo, 1994; OMS 2008). Como contrapartida se fueron desatendiendo aspectos terapéuticos de la relación médico-paciente, y se olvidaba elementos que facilitaban la visión holística e integral del paciente (Matarazzo, 1994). En este sentido, la Organización Mundial de la Salud propuso un cambio en la concepción de salud (OMS, 1948), definiéndola como un estado de completo bienestar físico, social y mental, y no solo la ausencia de enfermedad. Hecho que no se limitaba solo a la consideración de los aspectos biológicos de la enfermedad, sino que producía un cambio cualitativo en los criterios para definir la salud y/o enfermedad, con la inclusión de la dimensión psicológica y social. Esta 
propuesta, junto con los cambios mencionados en la epidemiología de los problemas de salud y la obra de autores fundamentales como Parsons (1951) o Mechanic (1968) desde la Sociología y la Sociología Médica respectivamente, dio lugar a la formulación del modelo bio-psico-social de la salud.

Desde este modelo, la salud se entiende como una realidad compleja, que se enmarca en un enfoque interdisciplinario, que supera el paradigma biologicista, y que se puede caracterizar como la síntesis de una multiplicidad de procesos interrelacionados que acontecen en la biología del cuerpo, en la mente del individuo y determinada incluso en su vertiente más social, por los programas políticos y los adelantos científicos y tecnológicos del ambiente que nos rodea (Briceño-Leon, 2000). Esta comprensión holística de la salud, incluye en el concepto de salud la capacidad humana para afrontar de manera autónoma los desafíos físicos, emocionales y sociales de la vida, y para funcionar con sentido de coherencia y bienestar personal aún padeciendo una enfermedad o discapacidad crónica, ya que actualmente lo habitual es llegar a envejecer con algún tipo de enfermedad crónica. La salud se puede entender como un 
medio para la realización de la vida diaria y no el objetivo de la vida (Huber et al., 2011).

En este contexto se resalta el estudio del comportamiento humano como eje vertebrador de los factores biológicos y sociales que ayuden a la promoción de la salud, o la prevención y tratamiento de la enfermedad. Esto supone además un cambio en los objetivos de la práctica médica ya que, por la alta prevalencia de trastornos o enfermedades crónicas, lo que se requiere no es la curación de la enfermedad en sí misma, sino facilitar la adaptación de cada persona a su contexto en función de los recursos biológicos y psicológicos que posea, resaltando la reciprocidad entre factores biológicos, psicológicos y sociales sobre la etiología y progresión de la enfermedad. En este punto resaltamos el papel que toma la Psicología de la Salud, definida en sus inicios como el conjunto de aportaciones, tanto de tipo educativo como científico y profesional, que proporcionan las diversas áreas psicológicas para la promoción y mantenimiento de la salud, la prevención y tratamiento de la enfermedad, la identificación de los correlatos etiológicos y diagnósticos de la salud, la enfermedad y sus consecuencias (Matarazzo, 1980, pag 815). 
1.2.- Modelo biopsicosocial y los inicios de la Psico-oncología

Los autores Zbigniew J. Lipowski (1924-1997) y George L. Engel (1913-1999) son considerados los pioneros del modelo biopsicosocial en medicina, aunque previamente desde la psiquiatría de enlace ya se aplicaba este modelo de trabajo a pacientes hospitalizados. Promulgado con el concepto psicobiología, Adolf Meyer (1915) desde una concepción holística de la salud, pretendía integrar en el tratamiento médico, el estudio psicológico de la persona dentro de su estructura biológica. Con esta concepción, el desarrollo de la psiquiatría de enlace alrededor de 1930, permitió introducir la valoración del psiquiatra como médico consultor, en la atención y cuidado del paciente hospitalizado (Karl \& Holland, 2013; Holland, 2004).

La concepción planteada por el modelo biopsicosocial aplicado a la oncología, ayudó a la psico-oncología a hacer sus primeras aportaciones y formalizar sus inicios a mitad de 1970 (Grassi, 2013; Holland, 2004). Aunque, se considera que las bases científicas de la psico-oncología surgieron en la década de 1950 con la figura de los psiquiatras Jacob E. Finesinger (1902-1959) del Massachusetts General Hospital, y Arthur M. 
Sutherland (1910-1971) del Memorial Sloan-Kettering Cancer Center, quienes publicaron los primeros manuscritos referidos al estado emocional, y respuesta que mostraban los pacientes ante el diagnostico y tratamiento del cáncer. Son los primeros trabajos realizados con pacientes oncológicos hospitalizados y en colaboración con los propios médicos que trataban el cáncer. Cabe destacar entre las aportaciones de A.M. Sutherland, la consideración que hacía del cáncer como una forma severa de estrés que amenaza los estilos habituales de afrontamiento de cada persona. Por tanto, este autor se distancia de las hipótesis que en aquel momento sugerían una etiología psicosomática del cáncer desde la medicina psicosomática. Además, consideraba que los aspectos psicológicos ante el cáncer no podían ser apartados de los aspectos físicos de la enfermedad, subrayando la singularidad en la reacción de cada persona ante la percepción de amenaza. Resaltó que en oncología más que en ninguna otra especialidad médica, la comunicación médico-paciente es un ingrediente esencial del propio tratamiento, comunicación que debería ser adaptada al contexto socio-cultural de cada paciente (Holland, 2004; Sutherland, 1957). En años posteriores confluyeron una serie de acontecimientos que propiciaron el surgimiento de varias unidades de psico-oncología en hospitales generales, promulgando un acercamiento multidisciplinar que favoreciera la atención médica integral del paciente con cáncer. Resaltan en este sentido los 
estudios epidemiológicos sobre la prevalencia de trastornos psiquiátricos en pacientes con cáncer, el surgimiento de la medicina conductual, y posteriormente la psicología de la salud a principios de 1980 con modelos teóricos aplicados a la promoción de estilos de vida saludables, y la validación de instrumentos de medida sobre calidad de vida, aspectos psicosociales del cáncer ó instrumentos de cribado sobre malestar emocional. También son mencionables en esos momentos las aportaciones de disciplinas como el trabajo social o la enfermería que fueron las primeras que intuitivamente proporcionaron soporte emocional $\mathrm{y}$ psicosocial a los pacientes con cáncer (Costa-Requena \& Ballester, 2011; Holland, 2002; Holland, 2004).

Siguiendo los principios del modelo biopsicosocial, la Psicooncología intenta evitar el reduccionismo de la moderna biotecnología, situando a la persona en todas sus dimensiones, como centro del encuentro terapéutico en oncología (Grassi, 2013). Actualmente el modelo biopsicosocial en psico-oncología permite una aproximación holística e integral al tratamiento del paciente oncológico. Un acercamiento dimensional hacia los aspectos promulgados desde el concepto de salud, en la vertiente del estado funcional del paciente $y$ sus relaciones 
interpersonales, incluyendo en este sentido la autonomía en la ejecución de tareas de autocuidado, movilidad y actividades de la vida diaria. Acercamiento dimensional asimismo, hacia aspectos físicos en la manifestación de los síntomas propios del tumor o de su tratamiento; y acercamiento hacia aspectos emocionales, referidos a síntomas de ansiedad y depresión secundarios a la enfermedad o su tratamiento, o a los recursos personales ante la enfermedad, como puedan ser aspectos espirituales, existenciales o de bienestar personal.

Aunque de modo simplificado se hace esta diferenciación, hay una evidente interrelación entre las tres variables, difícil de separar. En este sentido, nuestro trabajo se dirige a enfatizar el estudio de una de ellas, el apoyo social percibido y su relación con las otras dos dimensiones planteadas, aspectos biomédicos de la enfermedad y variables psicológicas.

1.3.- Apoyo social, calidad de vida relacionada con la salud y trastorno psicológico en pacientes con cáncer.

En la literatura científica se han proporcionado muchas evidencias sobre la importancia del apoyo social y las relaciones interpersonales en la mejora de los estilos de afrontamiento y respuesta adaptativa en pacientes 
con cáncer. El apoyo social es un concepto multidimensional que incluye tanto aspectos estructurales o cuantitativos del tamaño de la red social, como aspectos funcionales referidos a la valoración del contenido de la relación interpersonal. Varias dimensiones son incluidas en el apoyo social funcional, como la dimensión emocional/informacional o referida a poder obtener información sobre aspectos relacionados con la enfermedad y/o tratamiento, con expresión de compresión empática o guía y consejo; apoyo instrumental con la provisión de ayuda material o tangible; y apoyo afectivo al recibir muestras de empatía y afecto de los demás (De la Revilla, Luna del Castillo, Bailón \& Medina 2005; Sherbourne \& Stewart, 1991). Desde la teoría del Buffering-Stress, el apoyo social en sus diferentes vertientes se considera una variable moduladora ante efectos negativos de situaciones estresantes o amenazantes, que puede mitigar síntomas de malestar emocional o facilitar estrategias adaptativas de afrontamiento (Akechi, Okamura, Yamawaki \& Uchitomi, 1998; Devine, Parker, Fouladi \& Cohen, 2003; Helgeson \& McUmber, 2010; Kornblith et al., 2001), siendo el apoyo social un factor protector ante efectos adversos de la respuesta de estrés (Cohen \& McKay, 1984). Algunos estudios relacionan el escaso apoyo social percibido con altos niveles de malestar emocional en pacientes con cáncer (Devine et al., 2003; Parker, Baile, 
Moor \& Cohen, 2003). Además elevados niveles de malestar emocional se asocian con peor calidad de vida (Zabora, Brintzenhofeszoc, Curbow, Hooker \& Piantadosi, 2001). El apoyo social se considera un constructo a valorar dentro de la respuesta adaptativa del paciente al cáncer (Akechi et al., 1998; Helgeson \& McUmber, 2010), y resulta significativa su influencia en la percepción de la calidad de vida relacionada con la salud (Helgeson \& McUmber, 2010; Parker et al., 2003).

Al principio, el estudio del concepto de calidad de vida en oncología se planteó por la agresividad de los efectos secundarios que producían las primeras quimioterapias durante el tratamiento del cáncer. Así a finales de la década de 1940, Karnofsky y Burchenal publican una escala de 11 puntos para evaluar la capacidad funcional global del paciente al realizar una serie de actividades de la vida diaria. Posteriormente en la década de 1980, asociado a mejoras en el tratamiento médico y cambios en la concepción de la salud, autores como H. Schipper en Canadá, Neil K. Aaronson en Europa ó David Cella en EEUU, empezaron a validar instrumentos de calidad de vida con módulos específicos para cada tipo de tumor. Estos instrumentos incluían junto a sintomatología específica, la valoración que hace el paciente sobre su estado de salud al mantener una capacidad funcional normalizada en actividades cotidianas, dentro de un 
constructo multidimensional que incorpora a los aspectos del funcionamiento físico, rol social, y aspectos emocionales o dimensión mental. (Costa-Requena \& Ballester, 2011; Holland, 2002). Podríamos decir, que el concepto de calidad de vida, o más concretamente, calidad de vida relacionada con la salud, está referido a una valoración subjetiva sobre la salud, que varía con el tiempo, y que viene condicionada por los factores socio-demográficos y clínicos que caracterizan al paciente y su enfermedad en un momento determinado, y que determinan su bienestar físico y emocional (Costa-Requena \& Ballester, 2010). Al medir la respuesta adaptativa al cáncer, los instrumentos que evalúan calidad de vida parecen ser los más sensibles al cambio que manifiesta el paciente durante la enfermedad o su tratamiento. La respuesta adaptativa al cáncer se enmarca en un modelo biopsicosocial que enfatiza la influencia que ejerce el contexto social en la experiencia personal del paciente, ante la enfermedad oncológica (Brennan, 2001).

Como hemos comentado anteriormente, otro de los hitos que ayudó al fortalecimiento de los inicios de la psico-oncología fueron los estudios epidemiológicos sobre la prevalencia de trastornos psiquiátricos en pacientes con cáncer. El grupo de Derogatis en 1983, presenta uno de los 
primeros estudios que evalúan presencia de trastorno psiquiátrico en pacientes con cáncer utilizando criterios DSM-III. Los resultados mostraron prevalencias de alrededor del 47\%, y una alta frecuencia en la manifestación de trastornos adaptativos, en el 68\% de los diagnósticos psiquiátricos (Derogatis et al., 1983). También resultan elevadas las prevalencias del malestar emocional en pacientes con cáncer que oscilan entre el $43 \%$ y el $28 \%$, según el tipo de variables socio-demográficas y clínicas analizadas (Bringman et al., 2008; Costa-Requena \& Ballester, 2010; Grassi et al., 2004; Zabora et al., 2001). Estudios actuales y en población española señalan, que la morbilidad psicopatológica en pacientes con cáncer no es muy superior a la población general que se sitúa alrededor del 20\%, siendo la prevalencia de trastornos en pacientes con cáncer alrededor del 24\%, y la prevalencia de malestar emocional significativo del 42,5\% (Gil et al, 2008; Hernández et al., 2012). En este sentido, varios estudios señalan al bajo apoyo social percibido como factor de riesgo, predictivo de morbilidad psiquiátrica en pacientes con cáncer (Bringman et al., 2008; Eom et al., 2012; Mehert, Lehman, Graefen, Huland, \& Koch, 2010). 
Uno de los trastornos que ha despertado mayor interés en pacientes con cáncer es el trastorno de estrés post-traumático (TEP), partiendo de la consideración del cáncer como un estresor traumático con amenaza futura a la propia vida, que genera una ansiedad anticipatoria crónica. Se ha propuesto considerar esta entidad diagnostica en pacientes con cáncer aunque con características diferenciales en la presentación de sus síntomas. Los síntomas de reexperimentación a que se expone constantemente el paciente, principalmente asociado a signos externos de la enfermedad (visitas y pruebas médicas) o señales internas (sintomatología o molestias físicas secundarias al tratamiento) parecen más prevalentes durante el tratamiento oncológico. La evitación conductual o evitación cognitiva (reconocida como numing) son los síntomas más severos del TEP en cáncer, y resultan difícil de tratar durante las fases agudas del tratamiento médico. Así los déficits mnésicos o la sintomatología disociativa aparece entremezclada con la fatiga, dificultades de concentración,..., propios de los efectos secundarios del tratamiento. En este sentido, la visión de un futuro limitado también puede ser considerada realista y asociada al pronóstico de la enfermedad. La sintomatología de hiperactivación fisiológica, aunque también puede ser confundida con efectos secundarios del tratamiento (dificultades del sueño, irritabilidad, déficits de 
concentración,..), en etapa del post-tratamiento puede ser entendida como una respuesta al propio miedo a que aparezcan señales que indiquen recidiva de la enfermedad (Andrykowski \& Kangas, 2010). La prevalencia del TEP en cáncer afecta de un 2\% a 20\% de pacientes en algún momento desde el diagnostico a la superación de la enfermedad (Gil et al., 2008; Kangas, Henry, \& Bryant, 2002). Pocos estudios realizan seguimiento posttratamiento pero en algunos casos se señala una disminución de sintomatología de TEP del 22\% desde los 6 meses al 14\% al año del diagnostico (Kangas, Henry \& Bryant, 2005). La profundización en el estudio de la sintomatología del TEP durante el diagnostico, tratamiento y supervivencia del cáncer, puede ayudar a no patologizar sintomatología que puede ser entendida como un conglomerado de respuestas emocionales adecuadas a la intensidad del evento estresante al que se enfrenta el paciente.

En el marco del modelo biopsicosocial, emplazamos el estudio del apoyo social percibido en pacientes con cáncer y su influencia en variables médicas evaluadas a través de la percepción en la calidad de vida relacionada con la salud. También acogemos el estudio de la influencia del apoyo social percibido sobre la afectación emocional del paciente, o la manifestación de un trastorno psiquiátrico. Creemos de interés centrarnos 
en uno de los trastornos psiquiátricos, TEP, que aunque no resalta por su prevalencia, sí lo hace por su interferencia en la respuesta adaptativa que puede mostrar el paciente oncológico ante su enfermedad. 
2.-JUSTIFICACIÓN DE LOS ESTUDIOS 
El modelo biopsicosocial enmarca el enfoque de trabajo de los tres estudios presentados a continuación. Partiendo de una visión integral del paciente oncológico, se evalúa la afectación que produce el cáncer en diversos dominios en que se desenvuelve una persona, es decir, cómo puede afectar el cáncer a su estatus funcional, al bienestar psíquico del paciente, en la manifestación de molestias físicas o efectos relacionados con el tratamiento, y su interferencia en las relaciones con los demás.

En el modelo tradicional de investigación en psico-oncología, propuesto por Holland a principios de 1990, se intenta secuenciar estas variables. Así, el cáncer y su tratamiento son consideradas variables independientes, mientras la calidad de vida y supervivencia a la enfermedad son las variables resultado. Como variables mediadoras señalan los aspectos socio-demográficos y clínicos relacionados con la enfermedad, la personalidad, estilos de afrontamiento, apoyo social percibido y conductas relacionadas con un estilo de vida saludable (véase figura 1). 


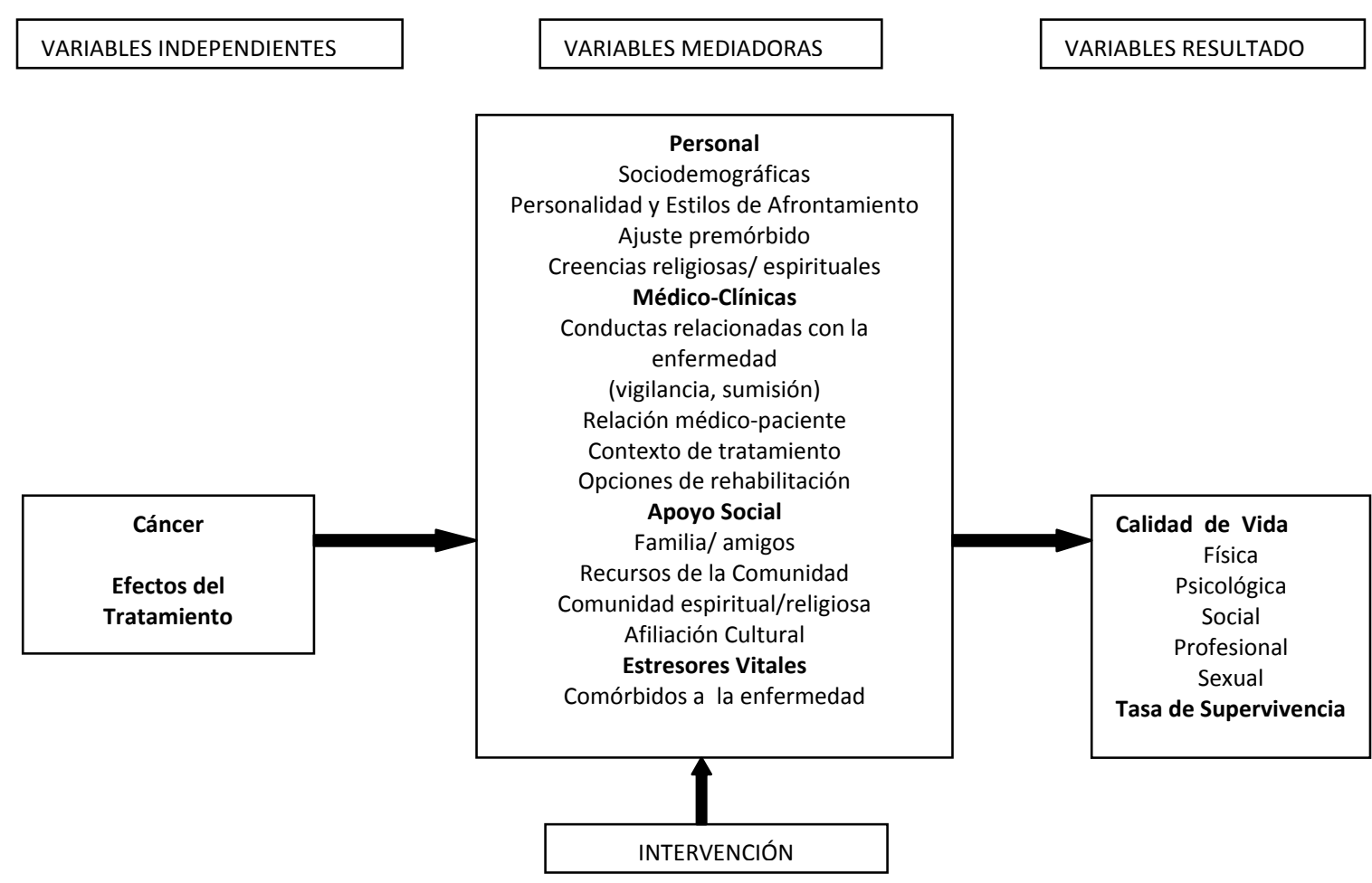

Figura 1. Modelo de investigación en Psico-oncología (Holland, 2002).

2.1.- Apoyo social percibido: conceptualización y dimensiones

En nuestro intento por resaltar el papel del apoyo social percibido ante el afrontamiento del cáncer, se estudia la interrelación entre algunas de las variables presentadas en el modelo de investigación propuesto por Holland (2002) en psico-oncología. Estudios previos señalan los efectos beneficiosos del apoyo social sobre la salud, aunque no se llega a esclarecer su mecanismo de acción (Uchino, Bowen, Carlisle \& Birmingham, 2012). 
Se ha propuesto, que de forma directa el apoyo social permite al paciente obtener información sobre la enfermedad y su tratamiento, e incrementa la motivación hacia conductas que promocionan la salud, como el ejercicio físico y una alimentación adecuada. También se ha argumentado que favorece el sentido de control y la autoeficacia en el manejo de la enfermedad. De forma indirecta el apoyo social ayudaría a fomentar la adherencia al tratamiento y proporcionaría apoyo instrumental para mantener las conductas saludables, como por ejemplo los desplazamientos a visitas médicas (Bloom, 1990; Uchino et al., 2012).

En los años 1970 surgen las primeras revisiones sistemáticas sobre los beneficios psicológicos del apoyo social en la salud, señalando que el apoyo social consigue aumentar el sentido de valía personal, la autoestima, y que refuerza las iniciativas de afrontamiento de cada persona al percibirse a sí mismo como miembro aceptado de un grupo social (Cohen \& McKay, 1984; Durá \& Garces, 1991; Rodríguez-Marín, Pastor \& Lopez-Roig, 1993). Estudios posteriores de la década de 1980 señalaron deficiencias para encontrar una definición consensuada sobre apoyo social, o una descripción de las variables que se debían integrar para evaluarlo, hecho que se mantiene en nuestros días (Uchino et al., 2012). En este sentido, las 
teorías propuestas en la década de 1980, para explicar la influencia del apoyo social sobre la salud marcaron tres líneas de investigación (Cohen \& McKay, 1984; Durá \& Garces, 1991). Una primera línea de investigación postulaba que el apoyo social tenía efectos directos sobre la salud tanto física como mental de las personas. Se trataba de una perspectiva epidemiológica cuyos resultados parecían indicar que las personas con relaciones y vínculos sociales viven más tiempo y tienen mejor salud. Una segunda línea de investigación, señalaba que el apoyo social reduce el impacto de los eventos estresantes que afectan a las personas (perdida de trabajo, enfermedad, perdida de un familiar,...), y no influye tan directamente a la salud, sino en el ajuste de la persona a un evento particular. Finalmente, la conceptualización más compleja explicaba que los efectos del apoyo social no influyen directamente ni sobre la salud, ni sobre los estresores, sino que modula la relación entre ambos, amortiguando el impacto de los eventos estresantes sobre la salud de la persona; es conocida como la teoría del Buffering-Stress. Según esta hipótesis el estrés psicosocial tendrá efectos negativos sobre la salud y bienestar de aquellas personas que no tengan apoyo social, mientras que estos efectos negativos se reducirán en aquellas personas con fuerte apoyo social. Mientras, el apoyo social no influirá en aquellas personas que no estén sometidas al estrés (Helgeson, 2003). 
Intentando llegar a una descripción integradora, recogemos la definición propuesta por Rodriguez-Marín (1993) de apoyo social, como aquel concepto dinámico e interactivo que incluye todo tipo de recursos del entorno favorecedores del mantenimiento de las relaciones sociales, la adaptación y bienestar de la persona dentro de una comunidad. En este sentido, los servicios que comprenden sistemas comunitarios de prestación económica, asistencial y/o sanitaria proveedores de apoyo social han sido denominados redes formales de apoyo, mientras son redes informales de apoyo aquellas relaciones sociales más básicas y tradicionales, que de forma natural se configuran en el entorno del paciente (amigos, familia, compañeros de trabajo,...). Así mismo, la evaluación del apoyo social referido a aspectos subjetivos, o de valoración cognitiva sobre las conductas de apoyo recibidas es denominada apoyo social percibido. Este, se considera un recurso estable en el tiempo relacionado con los esquemas relacionales de cada persona forjados en la infancia, mientras el apoyo social recibido estaría referido a un intercambio puntual de recursos (Uchino, 2009). 
Frente a los aspectos funcionales del apoyo social se pueden evaluar otras medidas estructurales, o de tamaño, referidos a la cantidad de interconexión en los recursos que posibilitan el apoyo social, como los indicadores de tamaño, densidad, o frecuencia de utilización del apoyo social (Durá \& Garces, 1991). Respecto al contenido en el carácter multidimensional del constructo de apoyo social, se diferencian distintos tipos de apoyo social funcional en la medida en que se valora la función específica que tienen las relaciones interpersonales. De las dimensiones funcionales del apoyo social percibido las más citadas son el apoyo emocional, como expresión de afecto y comprensión empática; apoyo informacional como guía, oferta de consejo e información; apoyo instrumental o provisión de ayuda material o tangible, y apoyo afectivo con demostraciones de amor, cariño o empatía; la interacción social positiva, referida al tiempo compartido con los demás en actividades placenteras o de ocio (De la Revilla Ahumada, Luna del Castillo, Bailón Muñoz \& Medina Moruno, 2005; Sherbourne \& Stewart, 1991). Esta diferenciación de dimensiones se adecua a la población de estudio. Así en población española la estructura factorial de la dimensión del apoyo informacional está unida al apoyo emocional. Podríamos pensar pues, que según cómo se da la información se está influyendo en la percepción de apoyo emocional recibido (Costa-Requena, Salamero \& Gil, 2007; de la Revilla et al., 2005). 
Resultados semejantes aparecen en población finlandesa, donde solo se diferencian dos dimensiones, el apoyo instrumental por una parte y por otra el apoyo emocional, informacional y afectivo por otro lado (Aato, Orhinmata \& Aro, 1995).

\section{2.- Cáncer y apoyo social percibido}

Describir las relaciones sociales proveedoras de apoyo social en una persona supone también indagar acerca de las funciones sociales percibidas por uno mismo como proveedoras de apoyo. Así, el apoyo social percibido tiene más impacto en la salud que el recibido (Helgeson, 1993), favoreciendo la respuesta emocional adaptativa de los pacientes con cáncer a la enfermedad y mitigando el deterioro que los pensamientos intrusivos generan ante la percepción de amenaza por la enfermedad (Lewis et al., 2001), siendo los pensamientos intrusivos y conducta evitativa los mediadores de la respuesta adaptativa a la enfermedad (Devine, et al., 2003). El apoyo social facilita la reestructuración de los pensamientos y discusión de emociones, a través del procesamiento de la información recibida, que ayuda a modular el bienestar emocional de los pacientes con cáncer (Lepore \& Helgeson, 1998). Otra forma en cómo el apoyo social 
puede mejorar las estrategias de afrontamiento es a través de la comparación social, mecanismo que opera gracias a la similaridad y aceptabilidad del estresor compartido por un grupo de personas, en este caso la enfermedad oncológica (Cohen \& McKay, 1984). Al estudiar la interrelación entre apoyo social, estilo de afrontamiento y adaptación a la enfermedad en pacientes con melanoma, el estilo de afrontamiento activo, y dirigido a la búsqueda de información y solución de problemas caracteriza la mayor percepción de apoyo social recibido, y se muestra inversamente relacionado con la tendencia a minimizar problemas y con altas puntuaciones en sintomatología depresiva (Scroevers, Ranchor \& Sanderman, 2003; Söllner et al., 1999).

Estudios previos relacionan el escaso apoyo social percibido con altos niveles de malestar emocional en pacientes con cáncer, asociado significativamente a un incremento de sintomatología ansioso-depresiva durante el seguimiento y finalización del tratamiento oncológico (Hipkins, Whitworth, Tarrier \& Jayson, 2004), y peor calidad de vida en sus dimensiones física y mental (Eom, et al., 2013; Zabora et al., 2001). El apoyo social se considera un constructo a valorar dentro de la respuesta adaptativa del paciente con cáncer al aminorar el impacto de los pensamientos intrusivos y respuesta evitativa de la enfermedad (Devine et 
al., 2003; Helgeson \& McUmber, 2010), y mejorar su calidad de vida relacionada con la salud (Parker et al., 2003; Helgeson \& McUmber, 2010). De las dimensiones funcionales, la percepción de apoyo instrumental se relaciona en sentido inverso con la dimensión física de calidad de vida, y marginalmente en sentido negativo también con la dimensión mental, lo que viene a indicar que la personas con pobre salud física y/o mental son las que más utilizan el apoyo instrumental, mientras la percepción de apoyo emocional es un predictor significativo de bienestar en la dimensión mental de calidad de vida (Bloom, Stewart, Johnston, Banks, \& Fobair, 2001). Las dimensiones estructurales de apoyo social percibido son las que correlacionan de forma significativa con la supervivencia al cáncer. Así, en mujeres con cáncer de mama socialmente aisladas, por la ausencia de familiares cercanos o sin amigos, se incrementa el riesgo de mortalidad comparado con pacientes con diez o más personas en su grupo de apoyo social (Helgeson \& McUmber, 2010; Kroenke, Kubzansky, Schernhammer, Holmes \& Kawachi, 2006).

En referencia a nuestro trabajo, con el primer estudio se pretende investigar la interrelación de las tres variables psicosociales que se consideran esenciales en la manifestación de la respuesta adaptativa al 
cáncer, esto es, calidad de vida relacionada con la salud, estilo de afrontamiento y malestar emocional, y como eje central en ellas la percepción de apoyo social. Aunque hay un cierto número de estudios en este tema, intentaremos partir de la interrelación entre estas variables aclarar cómo el tipo de respuesta de afrontamiento o la calidad de vida relacionada con la salud puede facilitar la percepción de apoyo social. Estudios previos señalan que la percepción de apoyo social, evaluada un año después del diagnóstico en pacientes con cáncer de cabeza y cuello, viene determinada por las condiciones de calidad de vida relacionada con la salud que manifiestan los pacientes (Karnell, Christensen, Rosenthal, Magnuson \& Funk, 2007).

El apoyo social es un concepto multidimensional, en su vertiente estructural y funcional, que sirve de amortiguador al malestar emocional y fortalecimiento de estrategias adaptativas de afrontamiento al cáncer. Pero a su vez, la presencia de un malestar emocional clínicamente significativo, o si llega al diagnóstico de trastorno mental, puede interferir en la percepción del apoyo social recibido, por ello consideramos de interés en el segundo artículo profundizar en el estudio de estas variables y su interrelación. 
Dentro del estudio de los trastornos psiquiátricos en pacientes con cáncer, aunque resulta complejo llegar a un claro diagnóstico de TEP, en varios trabajos previos se ha estudiado la prevalencia de esta sintomatología y su fluctuación a lo largo de la enfermedad. Diversas investigaciones muestran que la presencia de sintomatología del TEP tiende a disminuir por el tiempo transcurrido desde el diagnóstico del cáncer. Así, en el tercer estudio creemos de interés analizar en qué medida pueda influir longitudinalmente la percepción del apoyo social en la manifestación de sintomatología de TEP, durante el primer año tras finalizar el tratamiento oncológico. En este tercer estudio, analizamos longitudinalmente los datos de una muestra ambulatoria de pacientes perteneciente a las unidades funcionales de cabeza y cuello, colon y mama. Escogimos este tipo de tumores por ser según la revisión de la literatura científica, donde más se ha estudiado la prevalencia de TEP tras el diagnóstico del cáncer. 


\section{3.-HIPOTESIS Y OBJETIVOS}


A continuación señalamos las hipótesis planteadas para cada estudio

\section{1.- Hipótesis}

Estudio 1.

- La percepción de apoyo social estará relacionada con la mejor calidad de vida manifestada por el paciente en su dimensión física y mental, durante el tratamiento del cáncer.

- El tipo de respuesta de afrontamiento se relacionara diferencialmente con la percepción de apoyo social durante el tratamiento oncológico.

- En conjunto, la respuesta de afrontamiento y las dimensiones de calidad de vida relacionada con la salud influyen en la percepción de apoyo social, durante el tratamiento oncológico. 
Estudio 2.

- Dada la consideración del cáncer como evento estresante, se considera que la prevalencia de trastorno mental y malestar emocional significativo en pacientes oncológicos es superior a la prevalencia de la población general.

- La presencia de trastorno psiquiátrico y malestar emocional clínicamente significativo, determinará en sentido negativo la percepción de apoyo social.

Estudio 3.

- Durante el primer año tras finalizar el tratamiento oncológico la prevalencia de TEP y medias en percepción de apoyo social, serán diferente en los distintos momentos planteados de la evaluación, pretratamiento, post-tratamiento, a los 6 meses y al año de finalizar el tratamiento.

- Al comparar los tres tipos de tumores analizados, cabeza y cuello, colon y mama, aparecerán diferencias significativas en la percepción 
de apoyo social y sintomatología de TEP, durante el primer año tras finalizar el tratamiento oncológico.

- La percepción de apoyo social en pacientes con cáncer influirá diferencialmente en la sintomatología de estrés postraumático manifestada durante el primer año post-tratamiento oncológico.

\section{2.- Objetivos}

Los objetivos planteados desde esta investigación para cada estudio son los siguientes

Estudio 1

- Estudiar las relaciones entre la percepción de apoyo social y las dimensiones de calidad de vida relacionada con la salud, dimensión física y mental, y respuestas de afrontamiento al cáncer durante el tratamiento oncológico.

- Averiguar en qué medida influye el estilo de afrontamiento y las dimensiones de calidad de vida relaciona con la salud en la percepción de apoyo social, durante el tratamiento oncológico. 
Estudio 2

- Evaluar la prevalencia de malestar emocional clínicamente significativo y prevalencia de trastorno mental en la muestra de estudio.

- Evaluar si las diferencias en la percepción de apoyo social, en sus distintas dimensiones, pueden estar influidas por la presencia o no de trastorno psiquiátrico en pacientes con cáncer.

Estudio 3

- Evaluar longitudinalmente durante el primer año tras finalizar el tratamiento oncológico la prevalencia de TEP, y medias en percepción de apoyo social en la muestra analizada.

- Detallar en qué medida, durante el primer año post-tratamiento, influye diferencialmente la percepción de apoyo social en la manifestación de sintomatología de TEP. 
4.-MÉTODO Y RESULTADOS 
En este apartado se presentan los tres artículos publicados y que constituyen el componente empírico de la tesis doctoral. Estos estudios tienen como finalidad corroborar las hipótesis anteriormente planteadas y, por tanto, responder a los objetivos definidos.

\section{Articulo 1}

Costa-Requena G, Ballester Arnal R, Gil F. The influence of coping response and health-related quality of life on perceived social support during cancer treatment: Palliative and Supportive Care 2014; Epub ahead of print. doi:10.1017/S1478951514000418 


\title{
THE INFLUENCE OF COPING RESPONSE AND HEALTH RELATED
}

\section{QUALITY OF LIFE ON PERCEIVED SOCIAL SUPPORT DURING}

\section{CANCER TREATMENT}

\begin{abstract}
Objectives: In the biopsychosocial approach, perceived social support has served as a protective factor for psychological adjustment to cancer. This study aims to determine the influence of different coping responses and health related quality of life (HRQoL) domains on perceived social support during cancer treatment.
\end{abstract}

Methods: A cross-sectional analysis was carried out in a sample of 757 cancer outpatients. The Medical Outcomes Study Social Support Survey (MOS_SSS) was used to assess perceived social support. The Mental Adjustment to Cancer (MAC) scale measured coping response, and HRQoL was provided by Medical Outcomes Study Short Form-36 (SF-36). Multivariate analyses were carried out to examine the extent to which coping and HRQoL were associated with perceived social support.

Results: Coping response explained only $2 \%$ of the variance in perceived social support, but Hopelessness had a significant influence on perceived social support $(\mathrm{p} \leq 0.01)$. HRQoL, physical and mental domains made a significant contribution towards perceived social support resulting in around $10 \%$ of the total variance. More than coping response, HRQoL's physical and mental domains had an important influence on perceived social support during cancer treatment. 
Significance of Results: The findings of the current study report the importance of HRQoL domains in predicting perceived social support during cancer treatment, emphasising the holistic and multidisciplinary approach to facilitate adjustment to cancer.

What is of importance to us is the activity and behaviour of the total organism or individual as opposed to the activity of single, detachable organs. Adolf Meyer, 1915 (Karl \& Holland, 2013)

\section{INTRODUCTION}

The biopsychosocial model in cancer has considered the holistic approach to the patient, and has supported a patient's individual treatment; each cancer patient has their personal history, with their social relationships and illness adjustment response in the cancer context (Grassi, 2013). The conceptual model of biopsychosocial processes can be reported in three main domains: (1) physical well-being, refers to disease specific symptoms, or side effects of treatment, (2) psychological well-being refers to 
emotional and spiritual aspects, communication , cognition, coping style, subjective meaning of the cancer, and personal accomplishment, (3) interpersonal well-being refers to perceived social support and social role functioning. Adjustment to cancer has been defined as the cognitive and adaptive behavioural mechanism that takes place over time, within their social setting (Brennan, 2001). One way of capturing patient's adjustment response to cancer is using health related quality of life measures (HRQoL). The HRQoL's instruments have shown to be adequate for measuring change over time to adjustment responses to cancer (Brennan, 2001). Traditionally, HRQoL was considered a multidimensional concept, including patient's subjective evaluation of their physical function, disease and treatment related symptoms, psychological and social functioning (Ganz, 1994).

The relationship between HRQoL and social support is best understood using stress-buffering hypotheses, where social support improves HRQoL by facilitating an adaptive coping response (Helgeson, 2003). Additionally, in the integrative research model on psychosocial oncology, social support and coping response were among some of the 
psychosocial variables considered for mediating adjustment to cancer, HRQoL being the outcome variable for an adaptive response to cancer (Holland, 2002). Many studies have examined the predictive nature of social support by diminishing psychological comorbidity in cancer patients and survivors (Devine et al., 2003; Helgeson \& Cohen, 1996), and noted that a higher level of social integration was associated with better HRQoL (Michael et al., 2002; Lewis et al., 2001). The results showed that especially social support demonstrated its moderating effects on cognitive processing variables, such as intrusive thoughts about cancer (Lewis et al., 2001). Social support enabled patients to garner additional coping resources which facilitated emotional process of their cancer experience, through the verbal disclosure of thoughts and feelings (Devine et al., 2003; Lepore \& Helgeson, 1998; Zakowski et al., 2004). While many studies substantiated that perceived social support has been considered a significant mediator of psychological outcomes in cancer patients (Holland, 2002; Helgeson \& Cohen, 1996), the odd study has suggested that social support has no mediating effect on psychological well-being and that other personal resources like optimism, or self-transcendence should be included (Mathews \& Cook, 2009). Moreover, specifically in the context of cancerscreening setting, psychological well-being is influenced by social constraint and cognitive adaptation to a threatening event, rather than 
perceived social support or emotional processing (Andrykowski \& Pavlik, 2011).

Helgeson et al. (2004) examined patterns of adjustment to breast cancer over a 4 year period, where social support was distinguished from the different mental functions, illustrating that women who experienced decline in mental health also had fewer social resources. Regarding the functional aspects of social support relating to mental and physical wellbeing, it was suggested that patient's psychological resources affect their ability to utilise social support to improve personal physical well-being (Bloom et al., 2001). Perceived social support, measured as outcome variable, has been related to psychological processes of supportive relational schemas, coping responses or personality factors (Uchino, 2009; Den Oudsten et al., 2010).

An important line of inquiry in adjustment to cancer is remarked by the combined effect of coping response, social support and HRQoL. Considering three previous dimensions conceptualized in the biopsychosocial approach to cancer, this study was focused to highlight the 
contributions of underlying factors affecting perceived social support in cancer patients. The objective of this study was to assess the influence of the combined contribution of different types of coping responses and HRQoL domains in predicting perceived social support during cancer treatment. It was hypothesized that perceived social support was related with patients' coping response, at the same time as it was influenced by their HRQoL's, physical and mental domains.

\section{METHODS}

\section{Sample/Participants}

The study was conducted at a cancer centre. The inclusion criteria were: confirmed diagnosis of cancer, outpatients undergoing chemotherapy and radiotherapy or other oncology treatment and patients 18 to 80 years old. Patients with a low performance status (karnofsky<40\%), psychotic illness or significant cognitive impairment were excluded. The study was approved by the Institutional research board and obtained Ethics Committee Review. 


\section{Measurements}

A demographic questionnaire collected data about the patient's socio-demographic characteristics and medical status.

To measure coping response, the Mental Adjustment to Cancer (MAC) scale was utilised. This is a 40-item self-rating questionnaire, using a 4-point Likert scale, which includes five behavioural styles (Watson et al., 1988; Ferrero et al., 1994), these being: Fighting Spirit, HelplessHopelessness, Anxious Preoccupation, Fatalism, Avoidance (Denial). In the Spanish version of the MAC, which contained 28 items, the appropriate factor solutions also constituted five factors which accounted for $36.69 \%$ of total variance; the resulting factors were then titled as follows; Hopeless ( $\alpha$ $=.78)$, Anxious $(\alpha=.74)$, Resignation/Fatalism $(\alpha=.62)$, Illness Acceptance $(\alpha=.44)$ and Self-Safety Behaviour $(\alpha=.69)$, with acceptable internal consistency in the majority of the dimensions (Costa-Requena \& Gil, 2009). 
A general measure of HRQoL was provided by Medical Outcomes Study, Short Form-36 (SF-36) (Ware \& Sherbourne, 1992). This instrument measured two general health domains, physical health and mental health, divided by eight specific domains such as; physical functioning, limitations in performing roles because of physical health problems (physical roles), bodily pain, general health, vitality, social functioning, limitations in performing roles because of emotional health problems (emotional roles), and mental health. In each domain of the SF-36 scale, scores range from 0 (the worst possible measured health) to 100 (the best possible measured health). Hence, higher scores representing better functioning. The SF-36 health survey was translated and adapted into Spanish, and this version of the SF-36 had shown satisfactory reliability, Cronbach’s Alpha ranged from .71 to .94 for all dimensions (Alonso et al, 1995).

Social Support was assessed with Medical Outcomes Study Social Support Survey (MOS-SSS) (Sherbourne \& Stewart, 1991). This questionnaire measures five functional aspects of the perceived availability of social support (Emotional, Informational, Instrumental, and Affective 
support, and positive interaction). For each item, the respondent was asked to indicate how often each support was available to them if necessary. All but one item (i.e., number of close friends or relatives) are scored on a 5point Likert scale ranging from 1 (none of the time) to 5 (all of the time). For each subscale, simple algebraic sums were computed, with a higher score indicating a better perception of social support. Adequate psychometric properties of MOS-SSS have been established with Spanish validity, Cronbach’s alpha: .94 (Costa-Requena et al., 2007). By using a factor analysis in Spanish cancer patients three subscales of functional social support were distinguished: emotional/informational support, affective and instrumental support. Additionally, the total index of functional items was used as an overall measure of support (Sherbourne \& Stewart, 1991; Costa-Requena et al., 2007).

Procedure

With consecutive sampling, the samples were gathered from patients who had undergone oncology treatment, mainly with chemotherapy or a combination of chemotherapy with radiotherapy. Participants were 
recruited in the outpatient clinic while waiting for medical examination or chemotherapy treatment. All patients approached were informed of the objective of this study when asked to fill out the socio-demographic data and before signing the consent form agreeing to participate in the study. Data collection was conducted in a private area adjacent to the hospital ward. Permission to conduct this study was received from the Institutional Review Board of the hospital. The patients were first registered with a structured interview by a clinical psychologist to obtain socio-demographic data and Karnofsky functional index, medical characteristics were available from the patient's clinical record. Following this socio-demographic interview, patients were asked to complete the questionnaires MAC, SF-36 and MOS-SSS. Participants were asked to fill out the questionnaires themselves with an interviewer available for questions at all times. The assessment protocol lasted 20 to 45 minutes.

Statistical Analysis

Demographic and clinical related characteristics of the sample were examined using descriptive statistics. Pearson's correlation coefficient was 
performed to evaluate the association of different types of coping styles and two general HRQoL domains, physical health and mental health, with a global index of perceived social support. Then, to test the theoretical model of influence of coping response on perceived social support, two standard least-squares regression analyses were developed with significant correlation. In both cases, the global index of perceived social support was a dependent variable. Coping variables significantly correlated with perceived social support used in regression models. In the first model only different types of coping response were utilised as predicting variables, whilst in the second model, the two general health domains were added as independent variables. Multicollinearity was calculated by variation inflation factor (VIF) in the regression analyses. Inspection of residuals revealed whether the distribution could be considered fairly normal. Analyses were carried out using the Statistical Package for Social Sciences (SPSS version 15.0).

\section{RESULTS}

Subjects 
The interviewer originally approached 823 patients to participate in this study, but a total of 757 (91.9\%) patients finished the sociodemographic interview. The main reasons for refusal were lack of time ( $n=39)$, withdrew without explanation $(n=12)$, a disinterest in the study $(n=7)$ or not feeling well $(n=8)$.

In the sample, the median age was 55 years; 371 were men (49\%). Most of the patients, 569 (75.4\%) were married or had a partner. The sample represented many different types of cancer; the most prevalent being breast, colorectal and respiratory tumour. At the time of the study, 665 patients $(88,4 \%)$ were undergoing chemotherapy. Almost half of the patients, 347 (46.2\%), showed almost no symptoms of impairment. The summary of clinical and socio-demographic characteristics can be found in Table 1.

Perceived social support correlations

In bivariate correlation analyses, a higher level of perceived social support was significantly related to better HRQoL physical component $(\mathrm{r}=$ $.08 ; \mathrm{p} \leq .05)$ and HRQoL mental component $(\mathrm{r}=.28 ; \mathrm{p} \leq .01)$. Moreover, 
there was a negative association between perceived social support and coping response to cancer, that is, perceived social support was related with less Resignation ( $r=-.07 ; \mathrm{p} \leq .05)$, less Hopelessness $(r=-.13 ; \mathrm{p} \leq .01)$ and lower scores on Anxiety response to illness ( $\mathrm{r}=-.09$; $\mathrm{p} \leq .05$ ). Coping response with Illness Acceptance and Self-Safety Behaviour did not have a significant association with perceived social support. These correlations are shown in Table 2.

Influence of type of coping response and health related quality of life on perceived social support

In the first model, a standard regression analysis was calculated with significant bivariate correlations to identify the coping responses that influenced patient's perceived social support. In the second model, HRQoL domains were added with coping responses to assess their contributions on perceived social support. In colinearity diagnostics the VIF to predictors ranged from 1.01 to 1.14 , indicating multicollinearity did not affect the estimated $\beta$ parameter. 
Three coping responses were added Resignation, Hopelessness and Anxiety. This previous model reported an acceptable statistical analyses $(\mathrm{F}=4.50 ; \mathrm{p} \leq .01)$, the total equation was significant but only accounted for $1.5 \%$ of the variance. Hopelessness, with a negative coefficient, had a significant influence on perceived social support, as provided in Table 3. The second model in the regression analyses added the physical and mental component of HRQoL with coping response, and these variables improved the model's fit to explain perceived social support $(\mathrm{F}=14.88, \mathrm{p} \leq .01)$, the total equation equated to $9 \%$ of the variance. More than coping response, HRQoL's domains were significant predictors of perceived social support, particularly the mental component of HRQoL. The Hopelessness response failed to be significant when HRQoL's domains were added. The contribution of each predictor on the global index of perceived social support was demonstrated by a partial correlation, presented in Table 3.

\section{DISCUSSION}

Considering the biopsychosocial dimensions in the approach to cancer, social support has a significant role regarding the psychological 
adjustment to cancer (Helgeson et al., 2004). In order to better understand the mechanisms affecting perceived social support in cancer patients, the current study examined relative factors associated with it.

Social support was not considered simply a HRQoL aspect, but has been shown to effectively improve HRQoL in cancer patients (Bloom et al., 2001; Sherbourne \& Stewart, 1991), this could be a determining variable in a reciprocal relationship. The results of the present study suggest that better HRQoL, mental and physical domains, indicate better perceived social support during cancer treatment. The mental component of HRQoL was especially relevant in influencing perceived social support. Moreover in other studies, a higher level of perceived social support influenced better mental HRQoL by facilitating cognitive processing to reduce distress (Andrykowski \& Pavlik, 2011).

The earliest studies showed a relation between patient psychological response and adjustment to a diagnosis of cancer (Greer et al., 1979). Coping responses measured after cancer diagnosis predicted adjustment over a three year follow-up (Hack \& Degenr, 2004). Particularly, the 
Hopelessness response was associated with poor psychological adjustment (Schnoll et al., 1995; Shimizu et al., 2012); furthermore, at 10 years postdiagnosis, cancer patients' survival decreased after a high initial Hopelessness response (Hack \& Degenr, 2004; Watson et al., 2005). Also, it was found that coping strategies and cognitive variables may influence perceived social support (Den Oudsten et al., 2010; Uchino, 2009). Current findings showed that Hopelessness coping response was a negative determinant of patients' perceived social support. This became clear when Hopelessness response was considered a cognitive indicator of low positive affects (Beck et al, 2001). In turn, other studies showed that perceived social support was not a predictor of Hopelessness response in adjustment to cancer, but did predict other positive coping responses such as Fighting Spirit (Cicero et al., 2009).

Also noteworthy in the results of this study is the fact that when HRQoL domains were added to evaluate patient's perceived social support, coping response was not significant. These findings were parallel with the results described in other studies, where HRQoL domains were stronger predictors rather than coping behaviour for the patient's perceived psychosocial support needs (Brix et al, 2008). Positive health outcomes, 
with a reduction in treatment side effects might gradually diminish physical deterioration related to cancer, ensuring recovery.

This study had some limitations with its results. Firstly, the sample was taken from patients enrolled in only one hospital reducing the ability to generalize. Secondly, the cross-sectional design did not clarify a causal interpretation of the association between coping style and HRQoL domains regarding perceived social support. In future studies, it would be interesting to explore longitudinally the effect of changes in coping responses and HRQoL domains on perceived social support over time. Thirdly, the patients' socio-demographic and clinical variables were not analysed, including personality traits or personal resources such us optimism or selfesteem, and these could have an impact on psychological distress and perceived social support. Finally, contribution of coping response and HRQoL on different functional dimensions of perceived social support were also not analysed; this would strengthen differential specific effects on outcomes. 
The interest on perceived social support was reported in the integrative research model on psychosocial oncology (Holland, 2002), and in the early biopsychosocial principles in the approach to cancer. Both supported the need for an individualized doctor-patient communication, attending to the patient's psychosocial aspects and interpersonal relations (Alonso, 2004; Grassi, 2013). The current findings emphasise the importance of HRQoL domains in predicting perceived social support during cancer treatment. In this way, improvements on cancer treatment to facilitate patients' HRQoL, also provides psychological well-being. It is therefore essential to consider a holistic and multidiscipline approach to facilitate adjustment to cancer. In this line, following cancer diagnosis and treatment, a higher level of perceived social support in cancer survivors has been associated with greater likelihood of change towards healthy behaviours (Harper et al., 2007). Undoubtedly, in the health practice areas there is a wide range of factors influencing health care and healing process, including psychological and social factors, and not only biomedical management (Alonso, 2004; Grassi, 2013). 


\section{REFERENCES}

Alonso, Y. (2004). The biopsychosocial model in medical research: the evolution of the health concept over the last two decades. Patient Education and Counseling, 4, 239-244.

Alonso, J., Prieto, L. \& Antó, J.M. (1995). La versión española del SF-36 Health Survey (Cuestionario de Salud SF-36): un instrumento para la medida de los resultados. Medicina Clinica (Barcelona), 104, 771-776.

Andrykowski, M.A. \& Pavlik, E.J. (2011). Response to an abnormal ovarian cancer-screening test result: Test of the social cognitive processing and cognitive social health information processing models. Psychology and Health, 26(4), 383-397.

Beck, R., Perkins, T.S., Holder, R., et al. (2001). The cognitive and emotional phenomenology of depression and anxiety: Are worry and hopelessness the cognitive correlates of NA and PA. Cognitive Therapy Research, 25(6), 829-838.

Bloom, J.R., Stewart, S.L., Johston, M., et al. (2001). Sources of support and the physical and mental well-being of young women with breast cancer. Social Science \& Medicine, 53, 1513-1524. 
Brennan, J. (2001). Adjustment to cancer-coping or personal transition? Psycho-Oncology, 10, 1-10.

Brix, C., Schleussner, C., Füller, J., et al. (2008). The need for psychosocial support and its determinants in a sample of patients undergoing radiooncological treatment of cancer. Journal of Psychosomatic Research, 65, 541-548.

Cicero, V., Lo Coco, G., Gullo, S., et al. (2009). The role of attachment dimensions and perceived social support in predicting adjustment to cancer. Psycho-Oncology, 18, 1045-1052.

Costa-Requena, G. \& Gil, F. (2009). The Mental Adjustment to Cancer scale: A psychometric analysis in Spanish cancer patients. PsychoOncology, 18, 984-991.

Costa-Requena, G., Salamero, M. \& Gil, F. (2007). Validación del cuestionario MOS-SSS de apoyo social en pacientes con cáncer. Medicina Clinica (Barcelona), 128, 687-691.

Den Oudsten, B.L., Van Heck, G.L., Van der Steeg, A.F.W., et al. (2010). Personality predicts perceived availability of social support and satisfaction with social support in women with early stage breast cancer. Support Care Cancer, 18, 499-508. 
Devine, D., Parker, P.A., Fouladi, R.T., et al. (2003). The association between social support, intrusive thoughts, avoidance, and adjustment following an experimental cancer treatment. Psycho-Oncology, 12, 453462.

Ferrero, J., Barreto, M.P. \& Toledo, M. (1994). Mental Adjustment to Cancer and quality of life in breast cancer patients: An exploratory study. Psycho-Oncology, 3, 223-232.

Ganz, P.A. (1994). Quality of Life and the Patient with Cancer. Cancer, 74(4), 1445-1452.

Grassi, L. (2013). Quam bene vivas referre: curing and caring in psychooncology. Psycho-Oncology, 22, 1679-1687.

Greer, S., Morris, T. \& Pettingale, K.W. (1979). Psychological response to breast cancer: Effect on outcome. Lancet, i, 785-787.

Hack, T.F. \& Degenr, L.F. (2004). Coping response following breast cancer diagnosis predict psychological adjustment three years later. Psycho-Oncology, 13, 235-247.

Harper, F.W.K., Schmidt, J.E., Beacham, A.O., et al. (2007). The role of social cognitive processing theory and optimism in positive psychosocial 
and physical behavior change after cancer diagnosis and treatment. PsychoOncology, 16, 79-91.

Helgeson, V.S. (2003) Social support and quality of life. Quality of Life Research, 12 (suppl 1), 25-31.

Helgeson, V.S. \& Cohen, S. (1996). Social Support and Adjustment to Cancer: Reconciling Descriptive, Correlational, and Intervention Research. Health Psychology, 15(2), 135-148.

Helgeson, V.S., Snyder, P. \& Seltman, H. (2004). Psychological and physical adjustment to breast cancer over 4 years: Identifing distinct trajectories of change. Health Psychology, 23, 3-15.

Holland, J.C. (2002). History of Psycho-Oncology: Overcoming Attitudinal and Conceptual Barriers. Psychosomatic Medicine, 64, 206-221.

Karl, S.R. \& Holland, J.C. (2013). Looking at thr Roots of Psychosomatic Medicine: Adolf Meyer. Psychosomatics, 54, 111-114.

Lepore, S.J. \& Helgeson, V.S. (1998). Social constraints, intrusive thoughts, and mental health after prostate cancer. Journal of Social and Clinical Psychology, 17(1), 89-106. 
Lewis, J.A., Manne, S.L., DuHamel, N., et al. (2001). Social Support, Intrusive Thoughts, and Quality of Life in Breast Cancer Survivors. Journal of Behavioral Medicine, 24(3), 231-245.

Mathews, E.E. \& Cook, P.F. (2009). Relationships among optimism, wellbeing, self-transcendence, coping, and social support in women during treatment for breast cancer. Psycho-Oncology, 18, 716-726.

Michael, Y.L., Berkman, L.F., Colditzm G.A., et al. (2002). Social networks and health-related quality of life in breast cancer survivors. A prospective study. Journal of Psychosomatic Research, 52, 285-293.

Roberts, K.J., Lepore, S.J. \& Helgeson, V. (2006). Social-cognitive correlates of adjustment to prostate cancer. Psycho-Oncology, 15, 183-192.

Schnoll, R.A., Mackinnon, J.R., Stolbach, L., et al. (1995). The relationship between emotional adjustment and two factor structures of the Mental Adjustment to Cancer (MAC) Scale. Psycho-Oncology, 4, 265-272.

Sherbourne, C.D. \& Stewart, A.L. (1991). The MOS Social Suport Survey. Social Science \& Medicine, 32, 705-714.

Shimizu, K., Nakaya, N., Saito-Nakaya, K., et al. (2012). Clinical biopsychosocial risk factors for depression in lung cancer patients: a 
comprehensive analysis using data from the Lung Cancer Database Project. Annals of Oncology, 23, 1973-1979.

Uchino, B.N. (2009). What a Lifespan Approach Might Tell Us about Why Distinct Measures of Social Support have Differential Links to Physical Health. Journal of Social and Personal Relationship, 26(1), 53-62.

Ware, J.R. \& Sherbourne, C.D. (1992). The MOS 36-Item Short-Form Health Survey (SF-36). Medical Care, 30(6), 473-481.

Watson, M., Greer, S., Young, J., et al. (1988). Development of a questionnaire measure of adjustment to cancer: The MAC scale. Psychological Medicine, 18, 203-209.

Watson, M., Homewood, J., Haviland, J., et al. (2005). Influence of psychological response on breast cancer survival:10-year follow-up of a population-based cohort. European Journal of Cancer, 41, 1710-1714.

Zakowski, S.G., Ramatim A., Mortonm C., et al. (2004). Written Emotional Disclosure Buffers the Effects of Social Constraints on Distress Among Cancer Patients. Health Psychology, 23 (6), 555-563. 
Table 1. Clinical and Demographic Data $(n=757)$.

\begin{tabular}{|c|c|c|}
\hline Mean Age (SD) & \multicolumn{2}{|c|}{$53.5(11.7)$} \\
\hline Median & \multicolumn{2}{|c|}{55} \\
\hline Mode & \multicolumn{2}{|c|}{59} \\
\hline Gender & $\mathrm{n}$ & $\%$ \\
\hline Male & 371 & 49 \\
\hline Female & 386 & 51 \\
\hline Partner situation & & \\
\hline Married/partnered & 569 & 75.4 \\
\hline Single & 80 & 10.6 \\
\hline Divorced /Separated & 58 & 7.7 \\
\hline Widowed & 48 & 6.4 \\
\hline Education level & & \\
\hline Primary & 413 & 54.7 \\
\hline High school & 295 & 39 \\
\hline University & 47 & 6.3 \\
\hline Personal Psychiatric Antecedent & 177 & 23.4 \\
\hline Family history of cancer & 445 & 58.9 \\
\hline Family death from cancer & 339 & 44.8 \\
\hline Karnofsky index & & \\
\hline Normal activity (100-90) & 201 & 27 \\
\hline Hardly any symptoms of impairment (80) & 347 & 46.2 \\
\hline Some symptoms of impairment (70-50) & 197 & 26.7 \\
\hline Time since diagnosis (months) & & \\
\hline
\end{tabular}




\begin{tabular}{|c|c|c|}
\hline $1-3$ & 250 & 33.1 \\
\hline $4-7$ & 215 & 28.5 \\
\hline 8-11 & 69 & 9.1 \\
\hline 12 or more & 221 & 29.3 \\
\hline Tumour stage & & \\
\hline Localized & 220 & 29.3 \\
\hline Regional & 242 & 32.2 \\
\hline Metastasis & 167 & 22.2 \\
\hline Not solid tumour & 122 & 16.2 \\
\hline Tumour site & & \\
\hline Breast & 168 & 22.2 \\
\hline Gastrointestinal & 162 & 21.4 \\
\hline Respiratory & 146 & 19.3 \\
\hline Genitourinary & 111 & 14.7 \\
\hline Not solid tumours & 123 & 16.3 \\
\hline Other solid tumours & 46 & 6.1 \\
\hline Oncology Treatment & & \\
\hline Surgery & 425 & 57.5 \\
\hline Adjuvant Chemotherapy & 663 & 88.4 \\
\hline Adjuvant Radiotherapy & 242 & 32.8 \\
\hline Hormonal Treatment & 57 & 7.8 \\
\hline Other & 36 & 4.8 \\
\hline
\end{tabular}


Table 2. Correlations between Perceived Social Support, Coping Style and HRQoL Domains.

\begin{tabular}{|c|c|c|c|c|c|c|c|}
\hline Variables & 1 & 2 & 3 & 4 & 5 & 6 & 7 \\
\hline 1. Social Support & ---- & & & & & & \\
\hline 2. Resignation & $-.07^{\mathrm{a}}$ & ---- & & & & & \\
\hline 3. Hopeless & $-.13^{\mathrm{b}}$ & $.17^{\mathrm{b}}$ & ---- & & & & \\
\hline 4. Anxiety & $-.09^{\mathrm{a}}$ & $.29^{\mathrm{b}}$ & .24 & ---- & & & \\
\hline 5. Acceptance Illness & .05 & .01 & .06 & $.12^{\mathrm{b}}$ & ---- & & \\
\hline 6. Self-Safety Behaviour & .05 & .06 & -.04 & .05 & $.17^{\mathrm{b}}$ & ---- & \\
\hline 7. HRQoL Physical & $.08^{\mathrm{a}}$ & $-.09^{\mathrm{a}}$ & $-.09^{\mathrm{b}}$ & -.02 & .03 & .04 & ---- \\
\hline 8. HRQoL Mental & $.28^{\mathrm{b}}$ & -.02 & $-.20^{b}$ & $-.15^{\mathrm{b}}$ & .02 & $\begin{array}{c}.07 \\
\mathrm{a}\end{array}$ & .01 \\
\hline${ }^{\mathrm{a}} \mathrm{P} \leq .05$ & & & & & & & \\
\hline
\end{tabular}


Table 3. Standardized Regression Analysis of Overall Global Index of Perceived Social Support.

\begin{tabular}{|c|c|c|c|c|c|}
\hline \multirow[b]{2}{*}{ Variables } & \multicolumn{5}{|c|}{ Perceived social support } \\
\hline & $\Delta \mathrm{R}^{2}$ & $\begin{array}{c}\text { Standardized } \\
\text { beta }\end{array}$ & $\mathrm{t}$ & Sig & $\begin{array}{c}\text { Partial } \\
\text { correlation }\end{array}$ \\
\hline \multicolumn{6}{|l|}{ Model 1} \\
\hline Resignation & & -.05 & -1.49 & .13 & -.05 \\
\hline Hopeless & & -.11 & -2.96 & .00 & -.11 \\
\hline Anxiety & & .00 & .04 & .96 & .00 \\
\hline & .01 & & & .00 & \\
\hline \multicolumn{6}{|l|}{ Model 2} \\
\hline Resignation & & -.06 & -1.65 & .09 & -.06 \\
\hline Hopeless & & -.05 & -1.48 & .13 & -.05 \\
\hline Anxiety & & .03 & 0.81 & .41 & .03 \\
\hline HRQL Physical Component & & .09 & 2.57 & .01 & .09 \\
\hline HRQL Mental Component & & .27 & 7.29 & .00 & .26 \\
\hline & .09 & & & .00 & \\
\hline
\end{tabular}


Articulo 2

Costa-Requena G, Ballester Arnal R, Gil F. Perceived Social Support in Spanish Cancer Outpatients with Psychiatric Disorder. Stress Health 2013; 29: 421-426. 


\section{PERCEIVED SOCIAL SUPPORT IN SPANISH CANCER}

\section{OUTPATIENTS WITH PSYCHIATRIC DISORDERS}

ABSTRACT

This study examines differences in perceived social support during oncology treatment of cancer patients, whilst taking into account the presence of psychiatric disorder. Of particular interest were cancer patients who received psycho-pharmacology treatment compared to those who did not. A total of 760 cancer outpatients were recruited from one hospital in Spain. Multivariate analysis of covariance with the general linear model procedure was used. The Medical Outcomes Study Social Support Survey was used to assess social support perceived. The Diagnostic Interview Schedule, using DSM-III-R criteria was utilised for the diagnosis of psychiatric disorders. There were significant differences between the patients diagnosed with a psychiatric disorder and those not diagnosed with psychiatric disorders in terms of perceived Emotional/Informational support $(\mathrm{F}=19.11, \mathrm{p}<0.01)$, Affectionate support $(\mathrm{F}=12.30, \mathrm{p}<0.01)$ and the Overall Support Index $(\mathrm{F}=16.73, \mathrm{p}<0.01)$. In patients requiring psycho-pharmacology treatment, significant differences were presented with Structural Support $(F=4.32, p<0.05)$, Emotional/Informational support perceived $(\mathrm{F}=7.87, \mathrm{p}<0.01)$, Instrumental Support $(\mathrm{F}=4.17, \mathrm{p}<0.05)$ and Overall Support Index $(\mathrm{F}=7.84, \mathrm{p}<0.01)$. Psychopharmacology treatment helps to increase the perception of social support received by the patient. Health care professionals could provide support that would normalize cancer patients' distress, taking into account the importance of perceived social support for the psychological well-being of patients. 


\section{INTRODUCTION}

Social support is considered a multidimensional concept that includes structural support, or the quantity of social ties that the personal network consists of. Functional social support is measured by a person's assessment of the meaningfulness of interpersonal relationships. The dimensions of functional support can involve instrumental assistance, sharing information about cancer or treatment, as well as cancer's emotional involvement, or affective support (Sherbourne \& Stewart 1991).

The extensive body of the literature about prevalence of psychological distress in cancer patients produced mixed results. Previous studies had estimated rates of clinically significant distress ranging between 29\% and 43\% (Zabora, Brintzenhofeszoc, Curbow, Hooker \& Piantadosi 2001). The variability across studies using formal psychiatric diagnosis criteria contributes to a wider range of psychiatric disorder, which has been estimated to be between $6 \%$ and $45 \%$ for cancer outpatients (Kissane et al., 2004, Culha et al. 2004, Gil et al., 2008). Adjustment disorders, characterised by the presence of either an anxious or depressed mood, or a 
mixture of both, are likely to be visible during the course of oncology treatment or cancer trajectory (Kissane et al., 2004, Gil et al., 2008; Bringmann et al., 2008). Predictors of psychiatric morbidity after cancer diagnosis had been given, showed low social support, physical functioning deteriorating, socio-demographic variables, metastases or complications of disease (Parker, Baile, Moor \& Cohen, 2003; Bringmann et al., 2008). In psychosocial adjustment to cancer, it has been reported how psychiatric morbidity in cancer patients was negatively associated with patient's health related quality of life (Parker et al., 2003; Devine, Parker, Fouladi \& Cohen 2003).

Social support may buffer some of the negative effects of lifethreatening illness by mitigating distress symptoms, and by enabling individuals to garner additional coping resources (Akechi, Okamura,Yamawaki \& Uchitomi, 1998; Kornblith et al., 2001; Devine et al., 2003, Helgeson \& McUmber, 2010). Others findings have suggested evidence of a relationship between poor perceived social support and high levels of psychological distress (Devine et al., 2003, Helgeson \& McUmber, 2010). Moreover, increased levels of distress were associated with a worse quality of life (Zabora et al., 2001). Finally, studies have provided evidence that a lowered perception of social support influences 
subsequent levels of distress, thus higher levels of distress may also tend to erode survivors' perceptions of social support over time. These higher levels of distress during and after treatment for breast cancer were associated with decreased survivors' perceptions of instrumental and emotional support from the partner (Helgeson, Snyde \& Seltman 2004; Talley, Molix, Schlegel \& Bettencourt, 2010).

Social support was shown to be an important component in a patient's psychological adjustment to cancer (Akechi et al. 1998, Helgeson \& McUmber 2010), health related quality of life (Helgeson \& McUmber 2010, Parker et al., 2003), and more so, their survival from cancer (Helgeson et al. 2004, Kroenke, Kubzansky, Schernhammer, Holmes \& Kawachi, 2006). The aim of this study was to assess differences in the distinguished dimensions of perceived social support among cancer outpatients diagnosed with a psychiatric disorder compared to those patients not diagnosed with a psychiatric disorder. Second, patients were receiving psycho-pharmacological treatment were compared to those who were not required to receive treatment.

\section{METHODS}




\section{Sample/Participants}

The study was conducted at the Duran i Reynals hospital, an oncology centre in Barcelona (Spain). The inclusion criteria were patients with a cancer diagnosis, outpatients who were currently receiving chemotherapy and radiotherapy or other oncology treatment, and were aged between 18 and 80 years old. Patients with a low performance status (karnofsky $<40 \%$ ) or who had a psychotic illness or significant cognitive impairment were excluded. The study was approved by the Institutional Research Board and obtained Ethics Committee Review of the hospital.

\section{Measurements}

A questionnaire collected data about the patient's socio-demographic characteristics and medical status.

Functional status of oncology patients was evaluated by the Karnofsky Performance scale (Karnofsky, Albelman, Craver \& Burchenal, 1948), this is an index rated from 0 to 100 in steps of 10 , with low scores reflecting high impairment in normal activity and self-care. 
Psychological distress was assessed using the Hospital Anxiety and Depression Scale (HADS, Zigmond \& Snaith, 1983) which is a 14-item instrument with two dimensions, depression and anxiety (7 items for each), in this study the total HADS score has been utilised. Each item is rated on a 4-point scale from 0 to 3 . The HADS had been previously validated and had good internal consistency with the Spanish population (Chronbach's $\alpha$ of 0.86 for anxiety and 0.86 for depression) (Quintana et al. 2003).

In order to diagnose psychiatric disorders, the clinical interview was used. The Diagnostic Interview Schedule (DIS-I) (Spitzer, 1983), yielding that Spanish version was adapted from DSM-III-R criteria. A clinical psychologist was trained in order to standardise interviews and to use the diagnosis criteria.

Social Support was assessed with the Medical Outcomes Study Social Support Survey (MOS-SSS) (Sherbourne \& Stewart, 1991). This questionnaire measures five functional aspects of the perceived availability of social support (Emotional, Informational, Instrumental, Affectionate support, and positive interaction). For each item, the respondent was asked to indicate how often each support was available to them if needed. All but 
one item (ie, number of close friends or relatives) are scored on a 5-point Likert scale ranging from 1 (none of the time) to 5 (all of the time). For each subscale, simple algebraic sums were computed, with a higher score indicating a better perception of social support. The first item of the questionnaire measured is the structural support, which relates to the number of closed friends and closed relatives who provided support to the patient. Adequate psychometric properties of MOS-SSS have been established in Spanish validity, Cronbach's alpha: 0,94 (Costa-Requena, Salamero \& Gil, 2007). By using a factor analysis in Spanish oncology patients, three subscales of functional social support was distinguished: emotional/informational support, affectionate and instrumental support (Costa-Requena et al., 2007).

\section{Procedure}

The sample was selected consecutively from patients who had undergone oncology treatment. Participants were recruited in the hospital ward while they were waiting for medical examination or chemotherapy treatment and they were informed about the objective of this study. Patients who accepted to participate in the study were asked to sign the consent form and then were shown to a private area adjacent to the hospital ward to 
be interviewed. The patients were first assessed in a structured interview to obtain socio-demographic data, patients’ Karnofsky functional index was rated by their clinical nurse, whilst other medical characteristics were available from each patient's clinical record. After this, patients were asked to complete a screening test used to assess psychological distress, the HADS and the social support instrument, MOS-SSS. In HADS, the cutoff score for the screening of adjustment disorders was more than 13 (Razavi, Delvaux, Farvacques \& Robaye, 1990). Patients who scored 14 or higher on the HADS scale went through the psychiatric interview DIS-I. In a subgroup of patients who scored less than 14 (1 in 4 patients), some were randomly interviewed using the DIS-I to validate the results obtained with the HADS, suggesting presence of psychiatric disorders. Participants were asked to fill out the questionnaire themselves with an interviewer available for questions at all times. The assessment protocol lasted 25 to 60 minutes.

Statistical Analysis

Demographic and clinical related characteristics of the sample were examined using descriptive statistics. Multivariate analysis of covariance (MANCOVA) using the general linear model (GLM) multivariate 
procedure was undertaken. This can be particularly interesting when there are unequal numbers of observations across factor-level combinations. Socio-demographic variables such age, gender, family status and employed conditions were included as covariates. Normal distributed data was checked with Kolmogorov-Smirnov test and homogeneity of variance was verified. GLM multivariate analysis was calculated to evaluate the association of the 3 functional dimensions of the perceived social support as dependent variables, with diagnosis of psychiatric disease and psychopharmacology treatment as an independent variable. Statistical significancewas controlled using a restrictive alpha level of 0,01. Analyses were carried out using the Statistical Package for Social Sciences (SPSS version 15.0).

\section{RESULTS}

Participants

The interviewer originally approached 832 patients to participate in this study, but a total of 760 (91.3\%) patients agreed and completed all questionnaires. The main reasons for not participated in the study and filling in the questionnaire were lack of time $(n=43)$, withdrew without 
explanation $(n=13)$, a disinterest in the study $(n=8)$ or not feeling well $(n=8)$.

In the sample, median age was 55 years and there were 372 men (48.9\%). The sample represented many different types of cancer; the most prevalent being breast, colorectal and respiratory tumour. At the time of the study, 665 patients (88.3\%) were undergoing chemotherapy. A considerable proportion of patients 259 (34.4\%) required psychopharmacology treatment, these were mainly anxiolytics, tricyclic antidepressants or hypnotics. The summary of clinical and sociodemographic characteristics can be found in Table 1.

Psychological Distress and Social Support

On the HADS scale the mean score of sample was 9.6 (SD: 6.6). With regard to the overall sample, 189 patients (24.9\%) were above the 14 cut-off point in HADS used to indicate clinical distress, so it can be suspected they were suffering from psychiatric disorder. In the sample studied, a total of 578 (76\%) patients took part in the psychiatric interview DIS-I. A quarter of all patients, 197 (26\%) of the patients fulfilled the 
diagnostic criteria for the existence of psychiatric disorder. The percentage of psychopharmacology treatment in cancer treatment was 34\% which is higher than the percentage of patients with psychiatric disorders that was $26 \%$ as stated above. However, from the total number of patients with psychopharmacology treatment a quarter of patients (20.7\%) did not have criteria for psychiatric diagnosis. Therefore, a proportion of patients with psychiatric disorders (12.3\%) did not receive psychopharmacology treatment. Table 2 shows a description of psychiatric diagnosis.

The median number of close friends or relatives that overall patients reported in their social network was 8, mean number was 11.6 (SD: 13.8). More than half the patients $(n=479,64.9 \%)$ reported adequate social support, all of the time. In functional aspects of social support, the mean level perceived was a high value in Overall Support Index (Range 0-95; mean: 79.8; SD: 12.3), quite high in Emotional/Informational support (Range 0-60; mean: 52.2; SD: 9.2) and more increased in Instrumental support (Range 0-20; mean: 18.2; SD: 2.8) and Affectionate support (Range 0-15; mean: 14; SD: 1.8).

Differences on social support perceived considering presence of psychiatric disorder or psychopharmacology treatment 
A multivariate analysis was calculated to identify differences on dimensions of social support perceived (Structural Support, Emotional/Informational, Affectionate, Instrumental, overall Support Index), between those cancer patients diagnosed with a psychiatric disorder and those who were not diagnosed. Differences on patients who were receiving psychopharmacology treatment versus those who were not, were estimated as well on social support dimensions. Significant multivariate effects were obtained in the diagnosis of psychiatric disorder variable (Pillai's Trace: 0.03; $\mathrm{F}=4.45 ; \mathrm{p}<0.01$, partial eta squared: 0.03 ) and psychopharmacology treatment variable (Pillai’s Trace: 0.01; F= 2.35; $\mathrm{p}<$ 0.05; partial eta squared: 0.01). Then univariate analysis showed significant differences on psychiatric disorder with Emotional/Informational support, Affectionate support and Overall Support Index, as shown in Table 3. Meanwhile, psychopharmacology treatment obtained significant differences in structural and functional dimensions of social support except on Affectionate support.

\section{DISCUSSION}


Cancer is considered a life-threatening process that engenders a state of prolonged stress. On the other hand, social support is a resource that patients receive from family, friends or health care professionals to adjust to stressful situations (Helgeson \& McUmber, 2010). In the present study it was investigated structural and functional aspects of social support in different dimensions with two variables, cancer patients with psychiatric diagnosis and cancer patients receiving psychopharmacology treatment. The prevalence showed of psychological distress (24,9\%) and psychiatric diagnosis (26\%) in cancer outpatients was consistent with the range of prevalence reported in other studies (Culha et al., 2004; Gil et al., 2008; Bringmann et al., 2008), but it was more than prevalence of psychiatric disorder in general population, that is around 20\% (Haro et al., 2006). The differences of data between psychopharmacology treatment and psychiatric diagnosis highlighted that psychopharmacology treatment could alleviate psychiatric diagnosis, considering that $20.7 \%$ of patients with psychopharmacology treatment did not have psychiatric diagnosis. On the other hand, it was outlined that a proportion of patients with psychiatric diagnosis (12.3\%) did not have psychopharmacology treatment. When measuring social support perceived by cancer patients, results showed an adequate amount of social support perceived in global index, and in 
differenced dimensions of social support. Also, the size of a person's social network was similar to other studies (Kornblith et al., 2001).

Results of this study suggested that patients with diagnosis of psychiatric disease showed differences in perception of Emotional/Informational support and Affectionate support received, these differences were not seen in Structural support or Instrumental support. Patients receiving medication were more likely to have higher levels of social support received, except on Affectionate support. Considering that Affectionate support was found to be a significant predictor of psychological distress; in the absence of an intimate relationship, patients might have been less able to have meaningful reassurance from someone that they felt cared deeply about them (Kornblith et al., 2001).

Findings in others' research showed a significant but negative relation between Instrumental support to physical well-being, with symptom distress negatively related to physical well-being (Talley, Molix, Schlegel \& Bettencourt, 2010, Bloom, Stewart, Johston, Banks \& Fobair, 2001). In the current study, an explanation about Instrumental support could not be related with psychological distress, because patients may have 
an adequate health related quality of life despite following oncology treatment.

The result highlighted differences on Emotional/Informational support in patients with psychiatric disorder or undergoing psychopharmacology treatment indicating that patients with poorer mental health were more likely to report lower social support perceived (Helgeson et al. 2004, Bloom et al. 2001). Also it was emphasized, the importance of treatment of psychiatric comorbidity in cancer patients because of its influence in the perceived social support and other mediating factor on enhancing coping processes._In other studies, health care professionals were identified as sources strongly linked to Emotional/Informational support (Akechi et al. 1998). Access to accurate health information about their disease, treatment, side effects, and prognosis can be a valuable resource to enhance psychological adjustment in cancer patients (Parker et al. 2003). Health care professionals have the opportunity to normalise the concerns and symptoms of cancer patients, therefore considering the value of information as a resource in the cancer setting this may indeed help patients to cope better with cancer.

This study has some limitations that must be acknowledged. Firstly, the sample was taken from patients enrolled in only one hospital. This 
reduces the possibilities to make generalisations. Secondly, for future studies it would prove interesting to explore longitudinal assessment. As this is a cross-sectional study, information about pre-treatment or posttreatment psychological adjustment and social support is missing to specifically determine the adequate perceived need for social support over time. Moreover, cross-sectional design could diminish diagnosis rates of psychiatric disorders, considering that its assessment was done at one point in time during the course of cancer. Thirdly, patient's socio-demographic and clinical variables were not analysed, these could have an affect on psychological distress variations and social support perceived. Finally, this study suggests a positive benefit from psycho-pharmacology treatment on Affectionate support perceived; nevertheless, the results need to be interpreted cautiously due to cross-sectional design of the study, or the lack of a control group.

Although there are limitations to this study, these findings could suggest important implications in clinical practice. Health care professionals may promote interventions, such as counselling and use of support groups to help increase patients' emotional support. 


\section{REFERENCES}

Akechi, T., Okamura, H., Yamawaki, S., \& Uchitomi, Y. (1998). Predictors of patients'mental adjustment to cancer: patient characteristics and social support. British Journal of Cancer, 77, 23812385.

Bloom, J.R., Stewart, S.L., Johston, M., Banks, P., \& Fobair, P. (2001). Sources of support and the physical and mental well-being of young women with breast cancer. Social Science \& Medicine, 53, 1513-1524. Bringmann, H., Singer, S., Höckel, M., Stolzenburg, J.U., Krauß, O., \& Schwarz, R. (2008). Long-term corse of psychiatric disorders in cancer patients: a pilot study. GMS Psychosocial Medicine, 5: Doc03.

Costa-Requena, G., Salamero, M., \& Gil, F. (2007). Validación del cuestionario MOS-SSS de apoyo social en pacientes con cáncer. Medicina Clinica (Barcelona), 128, 687-691.

Culha, F., Baltalarli, B., Kalkan, N., Karadag, F., Ozdel, O., \& Karagoz, N. (2004). Psychiatric morbidity among cancer patients and awareness of illness. Support Care Cancer, 12, 161-167.

Devine, D., Parker, P.A., Fouladi, R.T., \& Cohen, L. (2003). The association between social support, intrusive thoughts, avoidance, and adjustment following an experimental cancer treatment. PsychoOncology, 12, 453-462. 
Gil, F., Costa-Requena, G., Pérez, F.J., Salamero, M., Sánchez, N., \& Sirgo, A. (2008). Adaptación psicológica y prevalencia de trastornos mentales en pacientes con cáncer. Medicina Clinica (Barcelona), 130, 90-92.

Haro, J.M., Palacin, C., Vilagut, G., Martinez, M., Bernal, M., Luque, I., Codony, M., Dolz, M., Alonso, J., \& Grupo ESEMeD-España. (2006). Prevalencia de los trastornos mentales y factores asociados: resultados del estudio ESEMeD-España. Medicina Clinica (Barcelona), 126, 445451.

Helgeson, V.S., \& McUmber, A.L. (2010). Social Environment and Cancer. In: Holland JC (ed) Psycho-Oncology, $2^{\text {nd }}$ edn. OxfordUniversity Press, New York.

Helgeson, V.S., Snyder, P., \& Seltman, H. (2004) Psychological and physical adjustment to breast cancer over 4 years: Identifing distinct trajectories of change. Health Psychology, 23, 3-15.

Karnofsky, D.A., Albelman, W.H., Craver, L.F., \& Burchenal, J.H. (1948). The use of nitrogen mustards in the palliative treatment of carcinoma. Cancer, 1, 634-656.

Kissane, D.W., Grabsch, B., Love, A., Clarke, D.M., Bloch, S., \& Smith, G.C. (2004). Psychiatric disorder in women with early stage and 
advanced breast cancer: a comparative analysis. Australian and New Zealand Journal of Psychiatry, 38, 320-326.

Kornblith, A.B., Herndon, J.E., Zuckerman, E., Viscoli, C.M., Horwitz, R.I., Cooper, M.R., Harris, L., Tkaczuk, K.H., Perry, M.C., Budman, D., Norton, L., \& Holland, J.C. (2001). Social support as a Buffer to the Psychological Impact of Stressful Life Events in Women with Breast Cancer. Cancer, 91, 443-454.

Kroenke, C.H., Kubzansky, L.D., Schernhammer, E.S., Holmes, M.D., \& Kawachi, I. (2006). Social Networks, Social Support, and survival After Breast Cancer Diagnosis. Journal of Clinical Oncology, 24, 11051111.

Parker, P.A., Baile, W.F., Moor, C., \& Cohen, L. (2003). Psychosocial and demographic predictors of quality of life in a large sample of cancer patients. Psycho-Oncology, 12, 183-193.

Quintana, J.M., Padierna, A., Esteban, C., Arostegui, I., Bilbao, A., \& Ruiz, I. (2003). Evaluation of the psychometric characteristics of the Spanish version of the Hospital Anxiety and Depression Scale. Acta Psychiatrica Scandinavica, 107, 216-221.

Razavi, D., Delvaux, N., Farvacques, C., \& Robaye, E. (1990). Screening for Adjustment Disorders and Major Depressive Disorders in Cancer In-Patients. British Journal of Psychiatry, 156, 79-83. 
Sherbourne, C.D., \& Stewart, A.L. (1991). The MOS Social Suport Survey. Social Science \& Medicine, 32, 705-714.

Spitzer, R.L. (1983). Structured Clinical Interview for DSM-III-R.New York State Institute, New York.

Talley, A., Molix, L., Schlegel, R.J., \& Bettencourt, A. (2010). The influence of breast cancer survivors' Perceived partner social support and need satisfaction on depressive symptoms: A longitudinal analysis. Psychology Health, 25, 433-449.

Zabora, J., Brintzenhofeszoc, K., Curbow, B., Hooker, C., \& Piantadosi, S. (2001). The prevalence of psychological distress by cancer site. Psycho-Oncology, 10, 19-28.

Zigmond, A.S., \& Snaith, R.P. (1983). The Hospital Anxiety and Depression Scale. Acta Psychiatrica Scandinavica, 67, 361-70. 
Table 1. Clinical and demographic data $(n=760)$.

\begin{tabular}{|c|c|c|}
\hline $\begin{array}{l}\text { Mean Age (SD) } \\
\text { Mode }\end{array}$ & $\begin{array}{r}53,5 \\
5\end{array}$ & $\begin{array}{l}(11,7) \\
59\end{array}$ \\
\hline $\begin{array}{l}\text { Gender } \\
\text { Men } \\
\text { Women }\end{array}$ & \begin{tabular}{|c|}
$\mathrm{n}$ \\
372 \\
388
\end{tabular} & \begin{tabular}{|c|}
$\%$ \\
48,9 \\
51.1 \\
\end{tabular} \\
\hline $\begin{array}{l}\text { Partner situation } \\
\text { Married/partnered } \\
\text { Divorced /Separated } \\
\text { Not married } \\
\text { Widowed }\end{array}$ & $\begin{array}{c}572 \\
58 \\
80 \\
48\end{array}$ & $\begin{array}{c}75,5 \\
7.7 \\
10.6 \\
6.3 \\
\end{array}$ \\
\hline $\begin{array}{l}\text { Family Status } \\
\text { Alone } \\
\text { With partner } \\
\text { Partner with children } \\
\text { Other family }\end{array}$ & $\begin{array}{c}57 \\
231 \\
349 \\
121\end{array}$ & $\begin{array}{c}7.5 \\
30.5 \\
46 \\
16\end{array}$ \\
\hline $\begin{array}{l}\text { Education level } \\
\text { Primary } \\
\text { High school } \\
\text { University }\end{array}$ & $\begin{array}{c}415 \\
295 \\
48 \\
\end{array}$ & $\begin{array}{c}54.7 \\
38.9 \\
6.4 \\
\end{array}$ \\
\hline $\begin{array}{l}\text { Employed condition } \\
\text { Labourer } \\
\text { Unskilled worker } \\
\text { Skilled worker } \\
\text { Manager or supervisor } \\
\text { Self-employed }\end{array}$ & $\begin{array}{c}359 \\
229 \\
92 \\
53 \\
24 \\
\end{array}$ & $\begin{array}{c}47.4 \\
30.2 \\
12.2 \\
7 \\
3.2\end{array}$ \\
\hline $\begin{array}{l}\text { Family history of cancer } \\
\text { Family dead by cancer }\end{array}$ & $\begin{array}{l}448 \\
342\end{array}$ & $\begin{array}{c}59.1 \\
45\end{array}$ \\
\hline $\begin{array}{l}\text { Karnofsky index } \\
\text { Normal activity (100-80) } \\
\text { Some symptoms of impairment } \\
(70-50)\end{array}$ & $\begin{array}{l}552 \\
208\end{array}$ & $\begin{array}{l}72.6 \\
27.4\end{array}$ \\
\hline $\begin{array}{l}\text { Tumour site } \\
\text { Breast } \\
\text { Gastrointestinal } \\
\text { Respiratory } \\
\text { Head and neck } \\
\text { Genitourinary } \\
\text { Other solid tumours } \\
\text { Not solid tumours } \\
\end{array}$ & $\begin{array}{c}168 \\
163 \\
146 \\
37 \\
112 \\
10 \\
123 \\
\end{array}$ & \begin{tabular}{|c|}
22.1 \\
21.5 \\
19.2 \\
4.9 \\
14.8 \\
1.3 \\
16.2 \\
\end{tabular} \\
\hline
\end{tabular}


Oncology Treatment

Surgery

Adjuvant Chemotherapy

Adjuvant Radiotherapy

66588.3

Hormonal treatment

$214 \quad 33$

Other

$57 \quad 6.7$

$74 \quad 8.9$

Table 2. Psychiatric disorders in cancer outpatients.

\begin{tabular}{|l|c|c|}
\hline Psychiatric Disorders & $\mathrm{n}$ & $\%$ \\
\hline Major depressive & 11 & 1.5 \\
Adjustment disorder anxiety & 50 & 6.5 \\
Adjustment disorder depressed mood & 61 & 8 \\
Adjustment disorder mixed symptoms & 29 & 3.8 \\
Anguish disorder with/without agoraphobia & 4 & 0.5 \\
Dysthymia & 13 & 1.7 \\
Generalized anxiety disorder & 2 & 0.3 \\
Phobia specific & 9 & 1.2 \\
Somatoform disorder & 4 & 0.5 \\
Post-Traumatic Stress disorder & 7 & 1 \\
Others disorders & 7 & 0.9 \\
\hline Psycho-pharmacology Treatment & 259 & 34.4 \\
\hline Psychiatric Disorders with Psycho-pharmacology treatment & 104 & 13.7 \\
\hline
\end{tabular}


Table 3. Differences of social support perceived in patients diagnosed by psychiatric disorder, or patients required psychopharmacology treatment.

\begin{tabular}{l|cccc}
\hline & Mean & SD & $F$ & $\begin{array}{c}\text { Partial Eta } \\
\text { Squared }\end{array}$ \\
\hline Psychiatric Disorder & & & & \\
Structural Support & 11.88 & 17.12 & 0.55 & 0.001 \\
Emotional/Informational & 49.44 & 10.71 & $19.11^{* *}$ & 0.027 \\
Affectionate & 13.56 & 2.27 & $12.30^{* *}$ & 0.018 \\
Instrumental & 17.79 & 3.07 & 4.70 & 0.005 \\
Overall Support Index & 76.31 & 14.22 & $16.73^{* *}$ & 0.024 \\
No Psychiatric Disorder & & & & \\
Structural Support & 11.59 & 12.59 & & \\
Emotional/Informational & 53.26 & 8.52 & & \\
Affectionate & 14.17 & 1.72 & & \\
Instrumental & 18.41 & 2.81 & & \\
Overall Support Index & 81.13 & 11.41 & & \\
\hline Psychopharmacology Treatment & & & & \\
Structural Support & 10.35 & 12.48 & $4.32^{*}$ & 0.006 \\
Emotional/Informational & 50.86 & 9.34 & $7.87^{* *}$ & 0.011 \\
Affectionate & 13.76 & 2.07 & 3.83 & 0.006 \\
Instrumental & 17.96 & 3.02 & $4.17^{*}$ & 0.006 \\
Overall Support Index & 78.01 & 12.42 & $7.84^{* *}$ & 0.011 \\
No Psychopharmacology Treatment & & & & \\
Structural Support & 12.15 & 13.99 & & \\
Emotional/Informational & 52.99 & 9.16 & & \\
Affectionate & 14.14 & 1.79 & & \\
Instrumental & 18.39 & 2.82 & & \\
Overall Support Index & 80.83 & 12.25 & & \\
\hline
\end{tabular}

${ }^{*} \mathrm{p}<0.05 ;{ }^{* *} \mathrm{p}<0.01$ 
Articulo 3

Costa-Requena G, Ballester Arnal R, Gil F. A 1-Year follow-up of podttraumatic Stress Disorder (PTSD) Symptoms and Perceived Social Support in Cancer. Psycho-Oncologie 2014; 8: 89-93. 


\section{A 1-YEAR FOLLOW-UP OF POSTTRAUMATIC STRESS DISORDER} (PTSD) SYMPTOMS AND PERCEIVED SOCIAL SUPPORT IN

\section{CANCER}

\section{ABSTRACT}

Aims: Diagnosis of PTSD symptoms in cancer patients fluctuates over the course of cancer according to the timing of assessment. In this longitudinal study, the prevalence of PTSD symptoms and the association between PTSD symptoms with the buffering variable of perceived social support were examined at one year follow-up.

Procedure: People with different types of cancer were assessed (breast cancer, head and neck and colorectal tumor), on four occasions: pre-treatment, at the end of cancer treatment, at 6 months post-treatment and 1 year following post-treatment. Multivariate analyses were used to assess associations of perceived social support in patients with PTSD symptoms at the aforementioned four time points.

Results: No significant differences in perceived social support were found at the various follow-up times. However, diagnosis of PTSD symptoms showed differences based on the time of assessment $(\mathrm{F}=5.50, \mathrm{p}=0.02)$. At pre and post-treatment, social support was negatively related to re-experiencing $(\mathrm{p}<0.00)$ and numbing $(\mathrm{p}<0.00)$ PTSD symptoms. At six months post-treatment, social support was negatively related to all symptoms of PTSD $(\mathrm{p}<0.00)$. Finally, at one year post-treatment, perceived social support was negatively related only to numbing symptoms $(\mathrm{p}<0.00)$ of PTSD.

Conclusion: Over the course of cancer, buffering effect of perceived social support had a specific influence on PTSD symptoms. 


\section{INTRODUCTION}

Longitudinal research indicates that PTSD symptoms in patients with cancer fluctuate subjectively over time. The prevalence rates for a lifetime cancer-related PTSD diagnosis varies from $4 \%$ to $17 \%$, depending on when the assessment is carried out. Previous research has predominantly focused on breast cancer patients and prostate cancer patients, and has shown evidence that the prevalence of PTSD symptoms declines following treatment completion as a result of their interaction with significant predictors of psychological co-morbidity, such as perceived positive social support or detrimental subjective threat of cancer $(1,2,3,4)$.

Several studies have shown how the influence of higher levels of perceived social support can influence the reduction of psychological distress and improve the quality of life in cancer patients, even at two- year follow-up $(5,6)$. Poor social support has been found to be a significant predictor of the occurrence of psychological co-morbidity, specifically PTSD symptoms, in cancer patients (7). In particular, for head and neck cancer patients, adequate levels of pre-treatment social support predicted favorable mental health one year after the diagnosis (8). In this line, the 
stress-buffering model holds that perceived social support protects patients from the potentially pathogenic influence of stressful events as it facilitated coping and adjustment responses to cancer. In prostate cancer, research has demonstrated that higher levels of perceived social support are a protective factor for health related quality of life (HRQoL) (6). Perceived social support serves as a buffer by facilitating coping with the adverse effects of multiple stressful situations over the course of the illness. Other studies have found that perceived social support predicted better mental functioning in cancer patients by facilitating cognitive processing, which can potentially lead to improvements in HRQoL (9).

The purpose of this study was, firstly, to assess longitudinally the prevalence and course of PTSD symptoms prior to and after treatment in cancer patients, and secondly, to explore the relationship between PTSD symptoms and perceived social support during the first year after completion of cancer treatment. In this second objective, it was hypothesized that perceived social support would differentially contribute to alleviate each of the described PTSD symptoms at four follow-up points; considering that psychological distress, physical symptoms, side effects of treatment, or patient's functional status could be alleviated in posttreatment follow-up time. 


\section{MATERIALS AND METHODS}

The study was carried out in a cancer hospital. The inclusion criteria were outpatients with a verified new cancer diagnosis, between 18 and 80 years of age, who able to understand the study and read the scales. Patients with a low activity and high medical needs status (Karnofsky<40\%), or significant cognitive impairment were excluded. The study was approved by the Institutional Review Board and the Ethics Committee.

Participants were consecutively recruited from functional units that specialized in the treatment of breast cancer, head and neck cancer, and colorectal tumors. All patients were informed of the objective of this study when they signed the consent form before they were asked to complete the questionnaire. Preliminary to oncology treatment (T1), the patients were assessed for socio-demographic information, and then completed the PCL$\mathrm{C}$ and MOS-SSS. Subsequent assessments were carried out at the end of the treatment (T2), at six moths post-treatment (T3) and one year following post-treatment in each type of tumor (T4).

A chart review was carried out to determine the patient's clinical and 
functional status. The presence of PTSD symptoms was assessed with the PTSD Checklist - Civilian version (PCL-C). This is a 17 item self-rating a screening tool using a 5- point Likert-type scale ranging from 1 (not at all) to 5 (extremely) for each item. The PCL-C provides a continuous score based on number and severity of PTSD symptoms according to DSM-IV criteria. The questionnaire yields a total score, as well as PCL-C's dimensions. The Spanish version of the PCL-C total score showed an acceptable reliability of $\alpha=0.90$, with a three-factor solution consisting of Hyperarousal / Re-experiencing $\pm \alpha$ 0.87, Numbing $\pm \alpha 0.78$ and Avoidance $\pm \alpha=0.69$ (10). PTSD diagnosis was determined using the cutoff score method, with the recommended score for cancer patients of 44 (1).

Social support was assessed with the Medical Outcomes Study Social Support Survey (MOS-SSS). This questionnaire measures functional aspects of the perceived availability of social support. For each item, the respondent was asked to indicate how often each support was available to them if needed. Items are scored on a 5-point Likert scale ranging from 1 (none of the time) to 5 (all of the time). For the total score algebraic sums were computed, with a higher score indicating a better perception of social support. Adequate psychometric properties of MOS-SSS have been 
established in the Spanish version, with a Cronbach's alpha of 0,94 (11).

Descriptive statistics were carried out at the four different times to describe the response range on the PCL-C and MOS-SSS in cancer patients. Repeated measures were calculated to compare differences across total PCL-C score over time. Correlation analyses were conducted between socio-demographic variables and site of tumor with PTSD symptoms and MOS-SSS. Those variables with a significant trend were included as controls. Multivariate analyses were used to assess associations of perceived social support in PTSD symptoms at the four time points. An estimate of effect size was calculated using partial Eta-squared. Analyses were carried out using the Statistical Package for Social Sciences (SPSS version 15.0).

RESULTS

Sixty-seven patients participated in the study. Of these, 55 completed the assessment at the end of the treatment, 50 patients completed the assessment at six months post-treatment, and 40 patients completed the assessment at one-year follow-up. Participants did not complete the study 
due to disinterest (13 participants), not localizable $(\mathrm{N}=7)$, indisposition $(\mathrm{N}=4)$, and death $(\mathrm{N}=3)$. At the initial assessment, 42(62.7\%) of the participants were female, and the median age was 52 years. The sample consisted mostly of breast cancer (53.7\%) patients. A total of 57 patients (85.1\%), were either married or partnered. The majority of the patients had undergone radical surgery (77.61\%), with additional oncology treatment. A summary of the medical and socio-demographic characteristics can be found in Table 1.

Comorbidity of PTSD symptoms and perceived social support

Using repeated measures of the general lineal model $(F=0.00$, $\mathrm{p}=0.92$ ) no differences were found between the MOS-SSS total scores at the initial and final assessments, means are shown in Table 2. PCL-C total scores showed differences over the different evaluation times $(F=5.50, p=$ 0.02), means of PCL-C total scores at different times are presented in Table 2. On the basis of the recommended cut-off score (PCL-C total score > 44) for cancer patients, at pre-treatment $9 \%$ of the sample was identified as likely to have significant PTSD symptoms, which increased to $12.7 \%$ at post-treatment and decreased to $10 \%$ of patients at six months and one-year follow-up post-treatment. Differences were not found between initial and 
follow-up times in each tumor site with regards to PCL-C total score or in perceived social support in each tumor site over time. These results are listed in Table 2.

Relationship between perceived social support and PTSD symptoms after cancer treatment

Spearman's rho correlation was calculated between PTSD symptoms and MOS-SSS total score, with age, gender, education status and site of tumor which yielded no significant associations. Multivariate analyses were carried out in order to ascertain the relationship between perceived social support and PTSD symptoms at the four time points. At pre-treatment and post-treatment, social support was negatively related to re-experiencing $(\mathrm{p}<0.00)$ and numbing $(\mathrm{p}<0.00)$ symptoms of PTSD. At six months posttreatment, perceived social support was negatively related to all symptoms of PTSD $(\mathrm{p}<0.00)$. Finally, at one year post-treatment, perceived social support was related only negatively to numbing symptoms $(\mathrm{p}<0.00)$ of PTSD, as are shown in Table 3.

\section{DISCUSSION}


This was a prospective study that examined the relationship between perceived social support and the course of PTSD symptoms after cancer treatment. Over the course of cancer, the prevalence estimate for PTSD in this study was $9 \%$ to $13 \%$ at different points in time, which was similar to the results found in previous studies $(1,3)$. The current results indicated significant differences between PTSD symptoms across evaluation times, with high rates of PTSD remaining constant. This is consistent with other research, which found that PTSD symptoms in cancer patients did not simply dissipate with time and that without appropriate treatment, chronic psychological distress could develop (2).

The study found that PTSD symptoms were most elevated at post treatment, which coincided with the lower levels of perceived social support, as has been observed in other studies (12). Moreover, shortly after treatment was completed, physical post treatment side effects caused decreases in HRQoL scores, which can also be considered a source of psychological distress (3). Social support was a predictor of improved HRQoL at three and twelve month follow-ups (8). Six months after cancer treatment, perceived social support was more strongly related to decrease psychological distress when patients had few physical complaints (12). As 
such, higher HRQoL at two-year cancer follow-up was reported by the buffered effect of social support on perceived stressful situations (6).

In PTSD, negative health outcomes on the physical component of HRQoL have been related specifically to hyperarousal symptoms (13). In this respect, previous studies showed that perceived social support had a moderating effect on the relationship between intrusive thoughts and HRQoL, that is, social support enhanced HRQoL by helping patients cognitively process their cancer experience (9). Over the course of cancer, current findings showed that perceived social support had specific influence on hyperarousal/re-experiencing symptoms (such as intrusive thoughts, irritability, hypervigilance,...) relieving them, but in this study the influence of perceived social support on HRQoL was not specifically assessed. At post-treatment evaluation, re-experiencing symptoms were associated with a lack of social support. This would make sense in cancer patients because many intrusions are future-oriented fears about one's health following treatment completion (14). Furthermore, several studies have found that cognitive processing about the subjective threat of cancer through social interactions mediated the relationship with psychological adjustment after cancer treatment (3). Similarly, this study found that 
perceived social support was negatively related to numbing symptoms of PTSD (or restricted affective expression) at all follow-up times; prior to cancer treatment, at post-treatment, at six months and one year posttreatment follow-up. Therefore, over the course of cancer, consistent with previous research, interventions with supportive group therapy specifically aimed to bolster the ability to cope with emotional aspects of cancer, helped to reduce symptoms of PTSD and psychological distress (4).

Several limitations of this study should be considered. Firstly, the small sample size and its heterogeneity decrease the generalized of the findings. The inclusion of a greater number of participants could show variations between the different cancer sites in relation to PTSD symptoms and perceived social support. The second limitation was the statistical analysis. Multivariate analyses did not obtain information about the causal association between social support and PTSD symptoms. Finally, the relationships between social support and psychological distress examined in this study may be influenced by factors that were not included in the study. In future research, it would be worthwhile to examine the role of clinical variables, such as specific side effects, toxicity of treatment, gender, education level, or previous psychological disorder. These factors could increase vulnerability to developing PTSD symptoms after cancer 
treatment (14).Furthermore, considering the stress-buffering model for future studies, HRQoL as an outcome variable could be included to assess the influence of perceived social support or cognitive functioning on global patients' well-being.

Despite these limitations, this study represents a step towards understanding the association between PTSD symptoms and perceived social support in cancer patients. Specifically, the findings highlight that buffering variable of perceived social support was differentially related to alleviate symptoms of PTSD over the course of cancer treatment and at follow-up. As such, patients may need different types of psychosocial support in accordance with the time elapsed following cancer treatment.

\section{REFERENCES}

1. Andrykowski MA, Cordova MJ, Studts JL, Miller TW. 1998. Posttraumatic Stress Disorder after Treatment for Breast Cancer: Prevalence of Diagnosis and Use of the PTSD Checklist- Civilian Version (PCL-C) as a Screening Instrument. J Consul Clin Psychol, 66: 586-590. 
2. Andrykowski MA, Cordova MJ, McGrath PC, Sloan DA, Kenady DE. 2000. Stability and change in posttraumatic stress disorder symptoms following breast cancer treatment: A 1-year follow-up. Psycho-Oncol, 9: 69-78.

3. Mehnert A, Lehmann C, Graefen M, Huland H, Koch U. 2010. Depression, anxiety, post-traumatic stress disorder and health-related quality of life and its association with social support in ambulatory prostate cancer patients. Eur J Cancer Care, 19: 736-745.

4. Levine EG, Eckhardt J, Targ E. 2005. Change in Post-Traumatic Stress Symptoms Following Psychosocial Treatment for Breast Cancer. Psycho-Oncol, 14: 618-35.

5. Eom C-S, Shin DW, Kim SY, Yang HK, Jo HS, Kweon SS, Kang YS, Kim J-H, Cho B-L, Park J-H. 2013. Impact of perceived social support on the mental health and health-related quality of life in cancer patients: results from a nationwide, multicenter survey in South Korea. Psycho-Oncol, 22(6): 1283-1290. DOI: 10.1002/pon3133

6. Zhou ES, Penedo FJ, Lewis JE, Rasheed M, Traeger L, Lechner S, Soloway M, Kava BR, Antoni MH. 2010. Perceived stress mediates the effects of social support on health-related quality of life among 
men treated for localized prostate cancer. J Psychosom Res, 69: 587590.

7. Mehnert A, Koch U. 2008. Psychological comorbidity and healthrelated quality of life and its association with awareness, utilization, and need for psychosocial support in a cancer register-based sample of long-term breast cancer survivors. J Psychosom Res, 64: 383-391.

8. Howren MB, Christensen AJ, Kamell LH, Van Liew JR, Funk GF. 2013. Influence of pre-treatment social support on health-related quality of life in head and neck cancer survivors: Results from a prospective study. Head Neck, 35(6): 779-787. DOI: 10.1002/hed.23029

9. Roberts KJ, Lepore SJ, Helgeson V. 2006. Social-cognitive correlates of adjustment to prostate cancer. Psycho-Oncol, 15: 183192.

10. Costa-Requena G, Gil F. 2010. Posttraumatic stress disorder symptoms in cancer: psychometric analysis of the Spanish Posttraumatic Stress Disorder Checklist-Civilian version. PsychoOncol, 19: 500-507. DOI: 10.1002/pon.1601 
11. Costa-Requena G, Salamero M, Gil F. 2007. Validación del cuestionario MOS-SSS de apoyo social en pacientes con cáncer. Med Clin (Barc), 128: 687-691.

12. De Leeuw JRJ, de Graeff A, Ros WJG, Hordijk GJ, Blijham GH, Winnubst JAM. 2000. Negative and positive influences of social support on depression in patients with head and neck cáncer: A prospective study. Psycho-Oncol, 9: 20-28.

13. Gómez L, Abrams MP, López-Martínez AE, Asmundson GJG. 2012. Trauma exposoure and health: The role of depressive and hyperarousal symptoms. J Traum Stress, 25: 641-648.

14. Kangas M, Henry JL, Bryant RA. 2002. Posttraumatic Stress Disorder following cancer. A Conceptual and Empirical Review. Clin Psychol Review, 22: 499-524. 
Table 1. Medical and demographic data $(n=64)$.

\begin{tabular}{|c|c|c|}
\hline Age & & \\
\hline Mean (SD) & \multicolumn{2}{|c|}{$52.3(10.64)$} \\
\hline Median & \multicolumn{2}{|l|}{52} \\
\hline Range & \multicolumn{2}{|c|}{$29-69$} \\
\hline & $\mathrm{N}$ & $\%$ \\
\hline \multicolumn{3}{|l|}{ Sex } \\
\hline Female & 42 & 62.7 \\
\hline \multicolumn{3}{|l|}{ Marital status } \\
\hline Married / partnered & 57 & 85.1 \\
\hline Divorced / Separated & 5 & 7.5 \\
\hline Single & 4 & 6 \\
\hline Widowed & 1 & 1.5 \\
\hline \multicolumn{3}{|l|}{ Education level } \\
\hline Primary & 50 & 74.6 \\
\hline High school & 12 & 17.9 \\
\hline University & 5 & 7.5 \\
\hline \multicolumn{3}{|l|}{ Tumor site } \\
\hline Breast & 36 & 53.7 \\
\hline Colorectal & 14 & 20.9 \\
\hline Head and neck & 17 & 25.4 \\
\hline \multicolumn{3}{|l|}{ Type of Treatment } \\
\hline Surgery & 52 & 77.61 \\
\hline Radiation & 42 & 62.68 \\
\hline Chemotherapy & 40 & 59.70 \\
\hline Hormonal & 26 & 38.80 \\
\hline
\end{tabular}


Table 2. Means and standard deviations (SD) of MOS-SSS total score and PCL-C total score, in each tumor site at different time points.

\begin{tabular}{|c|c|c|c|c|c|c|c|c|c|c|c|}
\hline \multicolumn{2}{|l|}{ Total score } & \multicolumn{2}{|c|}{ Total sample } & \multicolumn{2}{|c|}{ Head Neck } & \multicolumn{2}{|c|}{ Colorectal } & \multicolumn{2}{|c|}{ Breast } & \multirow[t]{2}{*}{$\mathrm{F}$} & \multirow[t]{2}{*}{ Sig } \\
\hline & & Mean & SD & Mean & SD & Mean & SD & Mean & SD & & \\
\hline \multirow[t]{4}{*}{ MOS-SSS } & $\mathrm{T} 1$ & 82.69 & 8.40 & 83.83 & 7.63 & 80.21 & 9.67 & 83.11 & 8.28 & 0.80 & 0.45 \\
\hline & $\mathrm{T} 2$ & 78.68 & 13.24 & 78.42 & 14.70 & 77.08 & 9.35 & 79.33 & 14.10 & 0.11 & 0.88 \\
\hline & T3 & 80.50 & 14.81 & 82.36 & 12.47 & 77.89 & 21.46 & 80.60 & 13.66 & 0.22 & 0.80 \\
\hline & $\mathrm{T} 4$ & 81.22 & 11.27 & 85 & 6.18 & 83.43 & 7.56 & 79.40 & 13.09 & 0.90 & 0.41 \\
\hline \multirow[t]{4}{*}{ PCL-C } & T1 & 28.52 & 11.81 & 29.53 & 9.73 & 27.63 & 12.81 & 28.40 & 12.57 & 0.10 & 0.90 \\
\hline & $\mathrm{T} 2$ & 28.69 & 12.48 & 31.33 & 13.27 & 26.82 & 12.64 & 28.34 & 12.37 & 0.39 & 0.67 \\
\hline & T3 & 27.32 & 12.18 & 27.45 & 9.59 & 28.67 & 16.69 & 26.87 & 11.89 & 0.07 & 0.92 \\
\hline & $\mathrm{T} 4$ & 25.33 & 10.22 & 30.35 & 11.88 & 28 & 15.44 & 22.96 & 7.42 & 1.97 & 0.15 \\
\hline
\end{tabular}


Table 3. Multivariate analyses of perceived social support with PTSD symptoms during the first year after cancer treatment.

\begin{tabular}{|c|c|c|c|c|c|}
\hline & PTSD symptoms & Mean (SD) & $\mathrm{F}$ & Sign & $\begin{array}{l}\text { Partial Eta } \\
\text { Squared }\end{array}$ \\
\hline \multirow[t]{3}{*}{ Pre-treatment } & Re-experiencing & 15.77(6.91) & 3.20 & 0.00 & 0.66 \\
\hline & Avoidance & $4.76(2.47)$ & 1.15 & 0.33 & 0.42 \\
\hline & Numbing & 7.99(3.57) & 2.52 & 0.00 & 0.61 \\
\hline \multirow[t]{3}{*}{ Post-treatment } & Re-experiencing & 15.44(7.12) & 8.80 & 0.00 & 0.91 \\
\hline & Avoidance & $4.87(2.31)$ & 1.65 & 0.11 & 0.67 \\
\hline & Numbing & 8.38(3.93) & 6.24 & 0.00 & 0.88 \\
\hline \multirow[t]{3}{*}{ 6moths post-treatment } & Re-experiencing & $14.70(6.84)$ & 4.04 & 0.00 & 0.79 \\
\hline & Avoidance & $4.44(2.04)$ & 3.55 & 0.00 & 0.77 \\
\hline & Numbing & $8.18(4.07)$ & 2.65 & 0.01 & 0.71 \\
\hline \multirow[t]{3}{*}{ 12moths post-treatment } & Re-experiencing & $13.72(5.47)$ & 1.85 & 0.10 & 0.63 \\
\hline & Avoidance & $4.13(2.26)$ & 2.09 & 0.06 & 0.66 \\
\hline & Numbing & 7.48(3.32) & 2.58 & 0.02 & 0.71 \\
\hline
\end{tabular}




\section{5.-DISCUSIÓN}




\section{1.-Discusión del Artículo 1.}

En el primer estudio se intentó analizar la interrelación de las tres variables que forman parte del modelo biopsicosocial en psico-oncología. De las tres variables propuestas, la primera está referida a aspectos físicos y emocionales de la enfermedad durante el tratamiento oncológico, evaluada con el concepto de calidad de vida relacionada con la salud en sus dimensiones física y mental. La segunda variable, referida a aspectos cognitivos como la respuesta de afrontamiento. Finalmente, la tercera variable referida a las relaciones interpersonales, evaluadas con el apoyo social percibido.

Estudios previos señalan que en pacientes oncológicos la percepción de apoyo social mejora la calidad de vida relacionada con la salud, en sus dimensiones física y mental (Bloom, et al., 2001; Helgeson \& McUmber, 2010; Howren, Christensen, Karnell, Van Liew \& Funk, 2012; Roberts, Lepore \& Helgeson, 2006). En este sentido, nuestros resultados corroboran que la mayor percepción de apoyo social se relaciona con mejor calidad de vida en su dimensión física y mental, durante el tratamiento oncológico. 
Destaca según la revisión de la literatura, la consideración de las mejoras que aporta el apoyo social percibido hacia la dimensión mental de la calidad de vida, por favorecer el procesamiento cognitivo de pensamientos intrusivos sobre el cáncer que pueden resultar amenazantes al paciente. Así algunos estudios plantean que el apoyo social permitiría incrementar las habilidades del paciente para asimilar y acomodar sus vivencias con la enfermedad oncológica, y favorecer una respuesta emocional adaptativa (Devine, et al. 2003; Lepore \& Helgeson, 1998; Roberts, et al., 2006). Así, en pacientes con cáncer de cabeza y cuello los altos niveles de apoyo social percibido en el momento del diagnostico, se asocian con mejoras en la dimensión mental de calidad de vida incluso al año de seguimiento (Howren et al., 2012).

Además, según lo planteado en nuestra segunda hipótesis, la percepción de apoyo social resulta diferente según el estilo de respuesta de afrontamiento. De este modo, nuestros resultados señalan que la mayor percepción de apoyo social se relaciona con una menor respuesta de resignación, de desesperanza, y bajas puntuaciones en la respuesta de ansiedad ante la enfermedad. En este sentido, la percepción de apoyo social favorece estrategias activas de afrontamiento ante la enfermedad oncológica, menor sentimiento de desesperanza, actitud fatalista y de 
resignación, lo que influye en una respuesta adaptativa al cáncer (Cicero, Lo Coco, Gullo \& Lo Verso, 2009; Grassi, Rosti, Lasalvia \& Marangolo, 1993). Por el contrario, respuestas de afrontamiento orientadas hacia la desesperanza, o la evitación de la enfermedad, generan malestar emocional significativo (Cicero, et al., 2009; Lehto, Ojanen \& kellokumpu-Lehtinen, 2005). Otros estudios, señalan también que la percepción de apoyo social está influida por la respuesta de afrontamiento o factores de personalidad, que actúan como mediadores en las altas valoraciones mostradas por los pacientes en calidad de vida y capacidad funcional, al fortalecer sentimientos de autoestima, autoeficacia o sensación de control, que propician mejoras en la salud física (Akechi et al., 1998; den Oudsten, Van Heck, Van der Steeg, \& Roukema, 2010; Uchino, 2009).

Finalmente, considerando la interrelación de las tres variables, al evaluar en qué medida influyen las dimensiones de calidad de vida y estilo de afrontamiento en la percepción de apoyo social, los resultados muestran que más que las respuestas de afrontamiento, son las dimensiones de calidad de vida las que resultan determinantes en la percepción de apoyo social. Resultados semejantes se muestran en pacientes oncológicos sometidos a radioterapia, donde las dimensiones física y mental de calidad 
de vida son predictores significativos de la percepción de apoyo social, tanto al inicio y como en la finalización del tratamiento (Brix, Schleussner, Fuller, Roehrig, Wendt \& Strauss, 2008). Cambiando el sentido en la interrelación de variables, el mayor grado de interferencia funcional de la enfermedad, la percepción escasa de apoyo social, y las respuestas de afrontamiento con escape o evitación de la enfermedad, son predictoras de peor calidad de vida (Lehto et al., 2005). Además al incluir el malestar emocional en la interrelación de variables, el deterioro del estado funcional del paciente durante el tratamiento oncológico se asoció con la respuesta de desesperanza y fatalismo, que son respuestas de afrontamiento implicadas con el malestar emocional (Akechi et al., 1998; Grassi et al., 1993). En pacientes con tumor de cabeza y cuello, al analizar si las molestias físicas afectan a la relación entre apoyo social y malestar emocional, en pacientes con leve deterioro de la salud física aparecen relaciones significativas entre percepción de apoyo social y sintomatología depresiva. En cambio esta asociación no es significativa cuando el estado físico del paciente es muy deteriorado (De Leeuw, De Graeff, Ros, Hordijk, Blijham \& Winnubst, 2000). Así mismo, en una investigación con seguimiento a cuatro años que analiza cuatro trayectorias diferentes de funcionamiento físico y mental que siguen las pacientes al diagnostico del cáncer de mama, se observó que tras el tratamiento oncológico la recuperación normalizada del nivel de 
funcionalidad física es un prerrequisito necesario, pero no suficiente para el bienestar psicológico de la paciente (Helgeson, Snyder \& Seltman, 2004). Dentro de una intervención holística y multidisciplinar en el paciente con cáncer, y siguiendo los principios del modelo biopsicosocial en psicooncología, las mejoras en el tratamiento médico del cáncer que favorezcan mejoras en la calidad de vida y estado funcional del paciente, aportaran su vez mejoras en el bienestar psicosocial del paciente, y facilitaran la respuesta adaptativa al cáncer.

\section{2.-Discusión del Artículo 2}

Según estudios previos, la prevalencia de malestar emocional en pacientes con cáncer oscila entre el 29\% y 43\%, dependiendo de la localización del tumor, estadio de la enfermedad, o tipo de instrumento de evaluación utilizado (Hernández et al., 2012; Mehnert \& Koch, 2008; Zabora et al., 2001). Según nuestros resultados la prevalencia de malestar emocional en pacientes oncológicos españoles es en torno al 25\%, ligeramente menor al mostrado por estudios internacionales. Así mismo, en nuestro estudio la prevalencia de trastorno psiquiátrico en pacientes con 
cáncer se sitúa alrededor del 26\%, dentro del rango mencionado por otros estudios que es entre el 6\% y 45\% en pacientes ambulatorios (Culha et al., 2004; Gil et al., 2008; Kissane et al., 2004; Mehnert \& Koch, 2008), y ligeramente superior a la prevalencia de trastorno psiquiátrico que muestra la población general española, que se sitúa alrededor del 20\% (Haro et al., 2006).

El tamaño de la red social, o apoyo estructural medio que refieren los pacientes es de 11 personas, semejante al mostrado en otros estudios que se sitúa en torno a 10 personas (Kornblith, et al., 2001). En nuestro estudio, la percepción de apoyo social en pacientes con cáncer en el índice global y en sus diferentes dimensiones funcionales es medio-alto, resultado acorde con otros estudios españoles donde la percepción de apoyo social en pacientes con cáncer es superior a la mostrada por pacientes con otras enfermedades crónicas, como pacientes con VIH (Edo \& Ballester, 2006).

Al analizar la relación entre trastorno psiquiátrico y las dimensiones funcionales de apoyo social, la presencia de trastorno mental en pacientes con cáncer condiciona en sentido negativo la percepción de apoyo social en las dimensiones de apoyo emocional/informacional, apoyo afectivo y en el índice global de la percepción de apoyo social. Estas diferencias 
significativas en la percepción de apoyo social según la presencia o no de trastorno psiquiátrico, no aparecen en la percepción de apoyo instrumental, o el tamaño de la red social.

La dimensión de apoyo afectivo se ha considerado como predictora de malestar emocional en pacientes con cáncer, por considerar que ante la ausencia de una relación íntima, los pacientes pueden verse menos capaces de tener sentimientos de seguridad de ser cuidados por alguien querido (Kornblith, 2001). Respecto a la dimensión emocional/informacional, otros estudios refieren que es la que está más relacionado con la calidad de vida y respuesta adaptativa al cáncer (Arora, Finney Rutten, Gustafson, Moser \& Hawkins, 2007; Helgeson, 2003). Concretamente, si el estresor relacionado con la enfermedad es controlable resulta útil el apoyo instrumental; en cambio ante estímulos estresantes incontrolables puede ser más beneficioso el apoyo emocional (Helgeson, 2003). Al analizar la fuente proveedora de este tipo de apoyo funcional se suele señalar a la familia, amigos e incluso profesionales sanitarios, como médicos y enfermeras que asumen el rol de referente emocional del paciente ante la enfermedad (Arora et al., 2007; Helgeson, 2003; Lehto et al., 2005; Mehnert, Lehman, Graefen, Huland \& Koch, 2010). 
Además, algunos estudios apuntan a la necesidad de considerar ciertas variables socio-demográficas como influyentes en la percepción de apoyo social, y que por mediación de la respuesta de afrontamiento, son determinantes del malestar emocional del paciente (Hernández et al., 2012; Lehto et al., 2005). Considerando las variables socio-demográficas en pacientes con cáncer, el carecer de relación de pareja se han mostrado predictor de bajos índices en la percepción de apoyo social, tanto en el índice global, como en las dimensiones de apoyo afectivo y emocional/informacional. Otras variables influyentes en el mismo sentido son el tener antecedentes de tratamiento psiquiátrico (Costa-Requena, Ballester Arnal \& Gil, 2014). Así mismo, personas de más edad, con bajos niveles educativos y que viven solas, tienen riesgo de mostrar una respuesta desadaptativa al cáncer y requerir recursos de apoyo psicosocial para el afrontamiento de la enfermedad (Akechi et al., 1998; Mehnert \& Koch, 2008).

\section{3.-Discusión del Artículo 3}

Según la revisión de la literatura, la prevalencia de TEP en pacientes con cáncer oscila entre el 4\% y 32\% (Kangas et al., 2002; Mehnert, 
Lehman, Graefen, Huland \& Koch, 2010). Hay pocos estudios longitudinales que hagan seguimiento sobre la prevalencia de trastornos psiquiátricos en pacientes con cáncer. En este sentido, al evaluar pacientes con cáncer de pulmón, los resultados mostraban una tendencia a la disminución de la sintomatología depresiva del 8\% al mes post-tratamiento, al 5\% a los 3 meses y al año de finalizar el tratamiento (Pradera, Cruzado, Olivares \& Hernando-Trancho, 2012; Uchitomi, Mikami, Nagai, Nishiwaki, Akechi \& Okamura, 2003). También, en pacientes con cáncer de mama la prevalencia de sintomatología depresiva disminuye del 33\% tras el diagnóstico, 24\% a los tres meses y sobre el 15\% al finalizar el primer año (Burgess, Cornelius, Love, Graham, Richards \& Ramirez, 2005). En cambio en sintomatología de TEP, se observa un incremento desde las 6 semanas post-tratamiento con prevalencias del 8\%, al año de finalizado el tratamiento con prevalencias del 12\%. Además de una fluctuación en la manifestación de la sintomatología del TEP, hay un incremento en los síntomas de re-experimentación y una disminución de sintomatología fisiológica en evaluaciones realizadas a los 2 años de finalizado el tratamiento en una muestra de pacientes con cáncer de mama, sin llegar a diferencias significativas (Kangas et al., 2002). 
En nuestro estudio, respecto a la sintomatología de estrés posttraumático aparecen diferencias significativas en su prevalencia según el momento de evaluación. Tras el diagnóstico y antes de empezar el tratamiento oncológico la prevalencia de síntomas de TEP es del 9\%, que incrementa al $12,7 \%$ en el post-tratamiento, y se mantiene estable en torno al 10\% a los 6 meses y año de finalizado el tratamiento. Estas prevalencias son más bajas que las presentadas por estudios similares que evalúan prevalencia de sintomatología de TEP en pacientes con cáncer de cabeza y cuello, y pulmón en el primer mes que son del 28\%, y a los 6 meses que son del 22\% tras el diagnóstico (Kangas et al., 2005). Respecto a la estabilidad de la sintomatología, en otros estudios con pacientes con cáncer de mama y a más largo plazo, la prevalencia de sintomatología de TEP permanece estable en las evaluaciones realizadas a 5 años tras finalizar el tratamiento (Mehnert \& Koch, 2008), lo que nos alerta sobre la necesidad de una intervención de soporte psicosocial en las primeras manifestaciones de la sintomatología de TEP para prevenir su instauración. En este sentido, aunque los pacientes tienen puntuaciones elevadas en apoyo social percibido durante el tratamiento oncológico, los resultados de nuestro estudio no aportan diferencias en los cuatro momentos evaluados del tratamiento oncológico. En cambio otros estudios señalan un detrimento 
del apoyo social con evaluaciones a 5 años tras finalizar el tratamiento (Mehnert \& Koch, 2008).

Respecto a la localización del tumor, estudios previos señalan diferencias significativas en prevalencia de sintomatología ansiosodepresiva según el tipo de tumor, siendo el cáncer de pulmón y los tumores ginecológicos los que más malestar emocional generan al paciente. En grado parecido se muestra el tumor de cabeza y cuello, y con menores niveles de malestar emocional el cáncer de mama y de colon (Zabora, 2001). En nuestro estudio respecto al tipo de tumor, no aparecen diferencias significativas ni en la percepción de apoyo social, ni en la presencia de sintomatología de TEP según la localización de los tumores evaluados, cáncer de mama, colon y, cabeza y cuello.

Al variar la presencia de malestar emocional según el momento de la enfermedad, también la influencia del apoyo social puede ser diferente según su curso, tras el diagnóstico, durante el tratamiento, a su finalización, o en las visitas de seguimiento post-tratamiento. La percepción de apoyo social en pacientes con cáncer de próstata se relaciona de forma inversa con sintomatología de ansiedad-depresión y síntomas de TEP (Mehnert et al., 
2010). En pacientes con cáncer de cabeza y cuello, a los 6 meses posttratamiento comparado con momento previo al tratamiento, hay una relación significativa entre más percepción de apoyo social y reducción de sintomatología depresiva (De Leeuw et al., 2000). Al estudiar la relación entre síntomas de TEP y apoyo social percibido en distintos momentos de la enfermedad, en el pre-tratamiento y post-tratamiento, la percepción de apoyo social se relaciona de forma negativa con los síntomas de reexperimentación y evitación cognitiva; a los 6 meses del post-tratamiento aparece una relación de la percepción de apoyo social con toda la sintomatología de TEP, mientras que al año la correlación en sentido negativo solo es significativa entre evitación cognitiva y percepción de apoyo social. La percepción de apoyo social ayuda al procesamiento cognitivo de pensamientos amenazantes relacionados con la enfermedad. Así mismo, el pobre procesamiento cognitivo se relaciona con altos niveles de pensamientos intrusivos y evitación, que conlleva el malestar emocional (Levine, Eckhardt \& Targ, 2005).

En nuestro estudio se señala que la percepción de apoyo social interviene en la interrelación con sintomatología de TEP. Según algunos estudios, específicamente la evitación cognitiva (numbing) parece ser la que pueda estar relacionada con respuestas disociativas del TEP, y son 
estas respuestas las que resultan predictoras en pacientes oncológicos de la severidad del TEP a los 6 meses del diagnostico (Kangas et al., 2005). La detección temprana de pacientes con factores de riesgo para desarrollar síntomas de TEP tras el diagnostico del cáncer, puede alertar sobre la necesidad de intervenciones psicológicas que reduzcan la cronicidad del trastorno. A sabiendas de que los síntomas de TEP pueden atenuarse con grupos de intervención que fomenten la percepción de apoyo social, y evitar la intensificación del trastorno durante el curso de la enfermedad (Levine, Eckhardt \& Targ, 2005).

\section{4.-Discusión General}

El modelo biopsicosocial, planteado desde los inicios de la psicooncología permite una aproximación holística al tratamiento del cáncer (Karl \& Holland, 2013). Este planteamiento además de propiciar un acercamiento integral al tratamiento del cáncer, lo hace desde una concepción del cáncer como enfermedad crónica, por la duración del tratamiento, por requerir seguimientos médicos a medio-largo plazo, y por el intento de mantener la mayor capacidad funcional del paciente en el contexto de la enfermedad. El apoyo social percibido desde la teoría del 
buffering-stress, se entiende como amortiguador de eventos estresantes en aspectos relacionados con la salud-enfermedad, además se considera el resultado de un proceso interrelacionado con efectos beneficiosos para el bienestar físico y emocional del paciente (Cohen \& McKay, 1984). Además, el apoyo social se considera una variable a considerar en la respuesta adaptativa del paciente al cáncer desde un modelo sociocognitivo (Brennan, 2001). Para averiguar cómo la interrelación entre las variables planteadas desde el modelo biopsicosocial pueden influir en la percepción de apoyo social, los resultados de nuestro primer estudio muestran que es determinante la influencia de la calidad de vida relacionada con la salud manifestada por el paciente, y en particular la dimensión mental del concepto, más incluso que las respuestas de afrontamiento consideradas predictoras del malestar emocional en pacientes con cáncer (Akechi et al., 1998; Grassi et al., 1993). Con ello, se enfatiza la consideración integral del tratamiento del cáncer, en sus aspectos físicos, emocionales y sociales, para propiciar la respuesta adaptativa a la enfermedad.

Al resultar significativa la implicación de la dimensión mental de calidad de vida en la percepción de apoyo social, resulta de interés estudiar el papel regulador que pueda tener el malestar emocional significativo, o 
diagnostico de trastorno mental en la percepción del apoyo social. Según se desprende del segundo estudio, la prevalencia de trastorno mental en pacientes con cáncer es del 26\%, ligeramente superior a la prevalencia en la población general. La interferencia por la presencia de un trastorno psiquiátrico en la percepción de apoyo social, resulta significativa para el índice global de apoyo social, y sus dimensiones funcionales de apoyo emocional/ informacional, y percepción de apoyo afectivo. En este sentido, suele ser la familia, amigos e incluso profesionales sanitarios, los que asumen el rol de referente emocional del paciente ante la enfermedad (Arora et al., 2007; Helgeson, 2003; Lehto et al., 2005). Esto también nos alerta sobre nuestro papel como sanitarios a la hora de atender las necesidades psicosociales del paciente con cáncer, y planificar estrategias de intervención que puedan ayudar a la mejora de su calidad de vida.

En el estudio sobre la prevalencia de sintomatología de TEP en pacientes con cáncer durante el curso de la enfermedad y tratamiento, se muestra que hay una variación en la manifestación de sintomatología de TEP durante el tratamiento oncológico y en fases de seguimiento, con incremento desde el pre-tratamiento (9\%), agudización en el posttratamiento (12.7\%), y estabilización (10\%), sin remisión espontanea del 
trastorno desde los 6 meses al año de finalización del tratamiento. Si además tenemos en cuenta que hay diferencias en la influencia del apoyo social sobre síntomas específicos del TEP durante el curso de la enfermedad, esto nos pueden alerta de la necesidad de la intervención psicológica para prevenir la intensificación del trastorno a largo plazo, considerando, como señalan varios estudios, la influencia que sobre la remisión del malestar emocional, y específicamente sintomatología de TEP, tiene la percepción de apoyo social (Levine, et al., 2005; Mehnert et al., 2010).

\section{5.- Limitaciones}

A los resultados de estos estudios cabe considerar algunas limitaciones. Primera, tener en cuenta que en los tres estudios la muestra está recogida en un solo centro, lo que puede acotar la generalización de resultados a un área geográfica concreta. Una segunda limitación está referida al diseño del estudio. En los dos primeros artículos el diseño de trabajo es transversal, lo que dificulta establecer diferencias en las variaciones de la percepción de apoyo social según el momento del tratamiento. Una tercera limitación referida al primer y tercer estudio es que no se analizaron variables socio-demográficas (edad, genero, nivel 
educativo, etc), ni variables clínicas (tiempo desde el diagnostico, tipo de tratamiento, etc.) que pudieran estar influyendo en la interrelación entre las variables de calidad de vida, estilo de afrontamiento y apoyo social percibido en un caso, ó relación entre sintomatología de TEP y apoyo social percibido en el caso del tercer estudio. Finalmente, en el tercer estudio el tamaño muestral para cada tipo de tumor es reducido, lo que reduce, asimismo, la posibilidad de encontrar diferencias en la percepción de apoyo social y sintomatología TEP según la localización del tumor. 


\section{6.-CONCLUSIONES}


A continuación presentamos las conclusiones generadas a partir de los objetivos planteados en los tres artículos.

- La mayor percepción de apoyo social se relaciona con mejor calidad de vida en su dimensión física y mental, durante el tratamiento del cáncer.

- La percepción de apoyo social favorece estrategias activas de afrontamiento ante la enfermedad oncológica, menor sentimiento de desesperanza, actitud fatalista y resignación.

- Las dimensiones de calidad de vida relaciona con la salud influyen más que las respuestas de afrontamiento en la percepción de apoyo social, durante el tratamiento oncológico. En concreto es la dimensión mental de la calidad de vida la que mayor aportación hace a la variabilidad en la percepción de apoyo social.

- La prevalencia de trastorno mental en pacientes con cáncer se sitúa alrededor 26\%, ligeramente superior a la media de la población 
general. Mientras el malestar emocional resulta significativo en alrededor del 25\% de pacientes oncológicos.

- La presencia de trastorno psiquiátrico y malestar emocional clínicamente significativo, determina en sentido negativo la relación con la percepción de apoyo social en las dimensiones funcionales de apoyo Emocional/Informacional y apoyo Afectivo, y en el índice global de apoyo social.

- Las medias en percepción de apoyo social permanecen sin cambios significativos en los distintos momentos planeados de la evaluación.

- La prevalencia de sintomatología de TEP es diferente en los distintos momentos planteados de la evaluación, del 9\% en el pre-tratamiento, $12,7 \%$ en el post-tratamiento, $10 \%$ a los 6 meses y al año de finalizar el tratamiento.

- Al comparar los tres tipos de tumores analizados, cabeza y cuello, colon y mama, no aparecen diferencias significativas en la percepción de apoyo social ni la presencia de sintomatología de TEP, 
tampoco las diferencias son significativas en los distintos momentos de la evaluación.

- La percepción de apoyo social influye diferencialmente en la sintomatología de TEP que manifiestan los pacientes con cáncer durante el primer año tras finalizar el tratamiento. En el pre y posttratamiento aparece una correlación negativa entre percepción de apoyo social, y síntomas de re-experimentación y evitación cognitiva (numbing); a los 6 meses la correlación es significativa entre percepción de apoyo social y la sintomatología de TEP; al año también la correlación negativa, es significativa pero sólo con síntomas de evitación cognitiva. 


\section{7.- REFERENCIAS BIBLIOGRAFICAS}


Aalto, A.M., Orhinmata, A., \& Aro, A. (1995). Social support and quality of life in Finnish general population. En: Rodríguez-Marín J, editor. Health psychology and quality of life research. Vol. 2. Alicante: Health Psychology Department, University of Alicante and Sociedad Valenciana de Psicología Social, p. 620-626.

Akechi, T., Okamura, H., Yamawaki, S., \& Uchitomi, Y. (1998). Predictors of patients'mental adjustment to cancer: patient characteristics and social support. British Journal of Cancer, 77, 23812385.

Andrykowski, M.A., \& Kangas, M. (2010).Posttraumatic Stress Disorder associated with cancer diagnosis and treatment. In J.C. Holland, W.S. Breitbart, P.B. Jacobsen, M.S. Lederberg, M.J. Loscalzo \& R. McCorkle (Eds.), Psycho-Oncology (pp. 348-57). New York: Oxford University Press.

Arora, N.K., Finney Rutten, L.J., Gustafson, D.H., Moser, R., \& Hawkins, R.P. (2007). Perceived helpfulness and impact of social 
support provided by family, friends, and health care providers to women newly diagnosed with breast cancer. Psycho-Oncology, 16, 474-486.

Bloom, J.R. (1990). The relationship of social support and health. Social Science \& Medicine, 30 (5), 635-637.

Bloom, J.R., Stewart, L.S., Johnston, M., Banks, P., \& Fobair, P. (2001). Sources of support and the physical and mental well-being of young women with breast cancer. Social Science \& Medicine, 53, 15131524.

Brennan, J. (2001). Adjustment to Cancer-Coping or Personal Transition? Psychooncology, 10, 1-10.

Briceño-Leon, R. (2000). Bienestar, salud pública y cambio social. En Briceño-Leon, R., De Souza, M., \& Coimbra, C., (coords). Salud y equidad: una mirada desde las ciencias sociales (pp. 15-24). Rio de Janeiro: Editora Fiocruz. 
Bringman, H., Singer, S., Höckel, M., Stolzenburg, J.U., Krauhb, O., \& Schawarz, R. (2008). Long-term course of psychiatric disorders in cancer patients: a pilot study. GMS Psychosocial Medicine, 5, Doc03.

Brix, C., Schleussner, C., Fu“ ller, J., Roehrig, B., Wendt, T.G., \& Strauss, B. (2008). The need for psychosocial support and its determinants in a sample of patients undergoing radiooncological treatment of cancer. Journal of Psychosomatic Research, 65, 541 - 548.

Burgess, C., Cornelius, V., Love, S., Graham, J., Richards, M., \& Ramirez, A. (2005). Depression and anxiety in women with early breast cancer: five year observational cohort study, British Medical Journal, 330, 702.

Cicero, V., Lo Coco, G., Gullo, S., \& Lo Verso, G. (2009). The role of attachment dimensions and perceived social support in predicting adjustment to cancer. Psycho-Oncology, 18, 1045 - 1052.

Cohen, S., \& McKay, G. (1984). Social support, stress and the buffering hypothesis: A theoretical analysis. In A Baum, SE Taylor \& JE Singer 
(Eds), Handbook of Psychology and Health. Hillsdale, NJ: Lawrence Erlbaum.

Costa-Requena, G., \& Ballester Arnal, R. (2010). Influencia de las características socio-demográficas y clínicas en la calidad de vida y malestar emocional del paciente oncológico. Psico-Oncologia, 7(2-3), 453-462.

Costa Requena, G., \& Ballester Arnal, R. (2011). El inicio de la Psicooncologia: una breve revisión. Cuadernos de Medicina Psicosomatica, 99, 21-28.

Costa-Requena, G., Ballester Arnal, R., \& Gil, F. (2014). Influence of demographic and clinical variables on perceived social support in cancer patients. Revista de Psicopatología y Psicología Clínica,

Costa-Requena, G., Salamero, M., \& Gil, F. (2007). Validación del cuestionario MOS-SSS de apoyo social en pacientes con cáncer. Medicina Clínica (Barc), 128, 687-691. 
Culha, F., Baltalarli, B., Kalkan, N., Karadag, F., Ozdel, O., \& Karagoz, N. (2004). Psychiatric morbidity among cancer patients and awareness of illness. Supportive Care in Cancer, 12, 161-167.

De la Revilla, L., Luna del Castillo, J., Bailón, E., \& Medina, I. (2005). Validación del cuestionario MOS de apoyo social en Atención Primaria. Medicina de Familia, 6, 10-23.

De Leeuw, J.R.J., De Graeff, A., Ros, W.J.G., Hordijk, G.J., Blijham, G.H., \& Winnubst, J.A.M. (2000). Negative and positive influences of social support on depression in patients with head and neck cancer: A prospective study. Psycho-Oncology, 9, 20-28.

Den Oudsten, B.L., Van Heck, G.L., Van der Steeg, A.F.W., \& Roukema, J.V. (2010). Personality predicts perceived availability of social support and satisfaction with social support in women with early stage breast cancer. Supportive Care in Cancer, 18, 499 - 508.

Derogatis, L.R., Morrow, G.R., Fetting, J., Penman, D., Piasetsky, S., Schmale, A.M., Henrichs, M., \& Carnicke, C.L.M. (1983). The 
prevalence of psychiatric disorders among cancer patients. JAMA, 249,751-7.

Devine, D., Parker, P.A., Fouladi, R.T., \& Cohen, L. (2003). The association between social support, intrusive thoughts, avoidance, and adjustment following an experimental cancer treatment. PsychoOncology, 12, 453-462.

Durá, E., \& Garcés, J. (1991). La teoría del apoyo social y sus implicaciones para el ajuste psicosocial de los enfermos oncológicos. Revista de Psicología social, 6 (2), 257-271.

Edo, M.T., \& Ballester, R. (2006). Estado emocional y conducta de enfermedad en pacientes con VIH/SIDA y enfermos oncológicos. Revista de Psicopatología y Psicología Clínica 11 (2), 79-90.

Engel, G.,L. (1977). The need for a new medical model: A challenge for biomedicine. Science, 196, 129-136.

Eom, C-S., Shin, D.W., Kim, S.Y., Yang, H.K., Jo, H.S., Kweon, S.S., Kang, Y.S., Kim, J.H., Cho, B.L., \& Park, J.H. (2013). Impact of 145 
perceived social support on the mental health and health-related quality of life in cancer patients: results from a nationwide, multicenter survey in South Korea. Psycho-Oncology, 22(6), 1283-1290. doi: 10.1002/pon.3133

Ferlay, J., Steliarova-Foucher, E., Lortet-Tieulent, J., Rosso, S., Coebergh, J.W.W., Comber, H., Forman, D., \& Bray, F. (2013). Cancer incidence and mortality patterns in Europe: estimates for 40 countries in 2012. European Journal of Cancer, 49(6), 1374-403. doi: 10.1016/j.ejca.2012.12.027

Gil, F.L., Costa-Requena, G., Pérez, F.J., Salamero, M., Sánchez, N., \& Sirgo, A. (2008). Adaptación psicológica y prevalencia de trastornos mentales en pacientes con cáncer. Medicina Clínica (Barc), 130, 90-92.

Grassi, L. (2013). Quam bene vivas referre: curing and caring in psycho-oncology. Psycho-Oncology, 22, 1679-1687. 
Grassi, L., Rosti, G., Lasalvia, A., \& Marangolo, M. (1993).

Psychosocial variables associated with mental adjustment to cáncer. Psycho-Oncology, 2, 11-20.

Grassi, L., Travado, L., Gil, F.L., Sabato, S., Rossi, E., \& SEPOS Group. (2004). Psychosocial morbidity and its correlates in cancer patients of the Mediterranean area: finding from the Southern European Psycho-Oncology Study. Journal of Affective Disorders, 83, 243-248.

Haro, J. M., Palacin, C., Vilagut, G., Martinez, M., Bernal, M., Luque, I., \& Grupo ESEMeD-España. (2006). Prevalencia de los trastornos mentales y factores asocidos: Resultados del estuio ESEMeD-España. Medicina Clínica (Barc), 126, 445-451.

Helgeson, V.S. (1993). Two important distinctions in social support: Kind of support and perceived versus received. Journal of Applied Social Psychology, 23, 825-845.

Helgeson, V.S. (2003). Social support and quality of life. Quality of Life Research, 12, 25-31. 
Helgeson, V.S., Snyder, P. \& Seltman, H. (2004). Psychological and physical adjustment to breast cancer over 4 years: Identifying distinct trajectories of change. Health Psychology, 23, 3-15.

Helgeson, V.S., \& McUmber, A.L. (2010). Social Environment and Cancer. In: Holland JC (ed) Psycho-Oncology, $2^{\text {nd }}$ edn. New York: Oxford University Press.

Hernández, M., Cruzado, J.A., Prado, C., Rodríguez, E., Harnández, C., González, M.A., Martin, J.C. (2012). Salud mental y malestar emocional en pacientes con cancer. Psicooncología, 9, 233-259. DOI: 10.5209/rev_PSIC.2013.v9.n2-3.40895

Hipkins, J., Whitworth, M., Tarrier, N., \& Jayson,G. (2004). Social support, anxiety and depression after chemotherapy for ovarian cancer: A prospective study. British Journal of Health Psychology, 9, 569-581.

Holland, J.C. (2002). History of Psycho-Oncology: Overcoming attitudinal and conceptual barriers. Psychosomatic Medicine, 64, 206221. 
Holland, J.C. (2004). IPOS Sutherland memorial lecture: An international perspective on the development of psychosocial oncology: Overcoming cultural and attitudinal barriers to improve psychosocial care. Psycho-Oncology, 13, 445-459.

Howren, M.B., Christensen, A.J., Karnell, L.H., Van Liew, J.R., \& Funk, G.F. (2013). Influence of pretreatment social support on healthrelated quality of life in head and neck cancer survivors: Results from a prospective study. Head \& Neck 35 (6), 779-787.

Huber, M., Knottnerus, J.A., Green, L., van der Horst, H., Jadad A.R., Kromhout, D., Leonard, B., Lorig, K., Loureiro, M.I., van der Meer, J.W.M., Schnabel, P., Smith, R., van Weel, C., Smid, H. (2011). How should we define health? British Medical Journal, 343, d4163. doi: 10.1136/bmj.d4163

Kangas, M., Henry, J.L., \& Bryant, R.A. (2002). Posttraumatic Stress Disorder following cancer. A Conceptual and Empirical Review. Clinical Psychology Review, 22, 499-524. 
Kangas, M., Henry, J.L., \& Bryant, R.A. (2005). The course of psychological disorders in the $1^{\text {st }}$ year after cancer diagnosis. Journal of Consulting and Clinical Psychology, 73, 763-768.

Karl, S.R., \& Holland, J.C. (2013). Looking at the roots of psychosomatic medicine: Adolf Meyer. Psychosomatics, 54, 111-114.

Karnell, L.H., Christensen, A.J., Rosenthal, E.L., Magnuson, J.S., \& Funk, G.F. (2007). Influence of social support on health-related quality of life outcomes in head and neck cancer. Head Neck, 29, 143-146.

Kissane, D. W., Grabsch, B., Love, A., Clarke, D. M., Bloch, S., \& Smith, G. C. (2004). Psychiatric disorder in women with early stage and advanced breast cancer: A comparative analysis. The Australian and New Zealand Journal of Psychiatry, 38, 320-326.

Kornblith, A.B., Herndon, J.E., Zuckerman, E., Viscoli, C.M., Horwitz, R.I., Cooper, M.R., Harris, L., Tkaczuk, K.H., Perry, M.C., Budman, D., Norton, L., \& Holland, J.C. (2001). Social support as a Buffer to the 
Psychological Impact of Stressful Life Events in Women with Breast Cancer. Cancer, 91, 443-454.

Kroenke, C.H., Kubzansky, L.D., Schernhammer, E.S., Holmes, M.D., \& Kawachi, I. (2006). Social networks, social support, and survival after breast cancer diagnosis. Journal of Clinical Oncology, 24 (7), 11051111.

Lehto, U.S., Ojanen, M., \& kellokumpu-Lehtinen, P. (2005). Predictors of quality of life in newly diagnosed melanoma and breast cancer patients. Annals of Oncology, 16, 805-816.

Lepore,S.J., \& Helgeson,V.S. (1998).Social constraints, intrusive thoughts, and mental health after prostate cancer. Journal of Social and Clinical Psychology, 17(1), 89-106.

Levine, E.G., Eckhardt, J., \& Targ, E. (2005). Change in post-traumatic stress symptoms following psychosocial treatment for breast cancer. Psycho-Oncology, 14, 618-635. 
Lewis, J.A., Manne, S.L., DuHamel, N., Johnson Vickburg, S.M, Bovbjerg, D.H., Currie, V., Winkel, G., \& Redd, W. H. (2001). Social support, intrusive thoughts, and quality of life in breast cancer survivors. Journal of Behavioral Medicine, 24(3), 231-245.

Matarazzo, J. (1980). Behavioral health and behavioral medicine: Frontiers for a new health psychology. American Psychologists, 35, 807-817.

Matarazzo, J.D. (1994). Health and behavior: The coming together of science and practice in psychology and medicine after a century of benign neglect. Journal of Clinical Psychology in Medical Settings, 1, 739.

Mechanic, D. (1962). The concept of illness behavior. Journal of Chronical Diseases, 15, 189-194.

Mehert, A., Lehman, C., Graefen, M., Huland, H., \& Koch, U. (2010). Depression, anxiety, post-traumatic stress disorder and health-related 
quality of life and its association with social support in ambulatory prostate cancer. European Journal of Cancer Care, 19, 736-745.

Mehnert, A., \& Koch, U. (2008). Psychological comorbidity and healthrelated quality of life and its association with awareness, utilization, and need for psychosocial support in a cancer register-based sample of longterm breast cancer survivors. Journal of Psychosomatic Research, 64, 383-391.

Organización Mundial de la salud (2008). Prevención y control de las enfermedades no transmisibles: aplicación de la estrategia mundial [Documento en línea]. Disponible: http:// www.who.int/gb/ebwha/pdf_files/A61/A61_8-sp.pdf [Consulta: 2014, Mayo 31]

Organización Mundial de la Salud (1948). Constitución de la Organización Mundial de la Salud [Documento en línea]. Disponible: http://www.who.int/gb/bd/PDF/bd46/s-bd46_p2.pdf [Consulta: 2007, Octubre 14] 
Parker, P.A., Baile, W.F., Moor, C., \& Cohen, L. (2003). Psychosocial and demographic predictors of quality of life in a large sample of cancer patients. Psycho-Oncology, 12, 183-193.

Parsons, T. (1951). The Social System. Glencoe: The Free Press.

Pradera, P., Cruzado, J.A., Olivares, Mª.E., \& Hernando-Trancho, F. (2012). Screening del malestar psicólogico en pacientes con cáncer de pulmón no microcítico con tratamiento quirúrgico. Psicooncología, 9, 299-316. DOI: 10.5209/rev_PSIC.2013.v9.n2-3.40899

Roberts, K.J., Lepore, S.J., \& Helgeson, V. (2006). Social-cognitive correlates of adjustment to prostate cancer. Psycho-Oncology, 15, 183192.

Rodriguez-Marin, J., Pastor, Ma.A., \& Lopez-Roig, S. (1993). Afrontamiento, apoyo social, calidad de vida y enfermedad. Psicothema, 5, 349-372. 
Scroevers, M.J., Ranchor, A.V., \& Sanderman, R. (2003). The role of social support and self-esteem in the presence and course of depressive symptoms: a comparison of cancer patients and individuals from the general populations. Social Science \& Medicine, 57, 375-385.

Sherbourne, C.D., \& Stewart, A.L. (1991). The MOS Social Suport Survey. Social Science \& Medicine, 32, 705-714.

Sociedad Española de Oncología Médica (2014). Cifras del Cáncer en España 2014 [Documento en línea]. Disponible: http:// www.seom.org/seomcms/images/stories/recursos/Las_cifras_del_cancer _2014. pdf [Consulta: 2014, Mayo 31]

Söllner, W., Zschocke, I., Zingg-Schir, M., Stein, B., Rumpold, G., Fritsch, P., \& Augustin, M. (1999). Interactive patterns of social support and individual coping strategies in melanoma patients and their correlations with adjustment to illness. Psychosomatics, 40 (3), 239250.

Sutherland, A.M. (1957). The psychological impact of postoperative cancer. Bull N Y Acad Med, 33(6), 428-445. 
Uchino, B.N. (2009). What a lifespan approach might tell us about why distinct measures of social support have differential links to physical health. Journal of Social Personality and Relationships, 26 (1), 53-62.

Uchino, B.N., Bowen, K., Carlisle, M., \& Birmingham, W. (2012). Psychological pathways linking social support to health outcomes: A visit with the "ghosts" of research past, present, and future. Social Science \& Medicine, 74, 949-957.

Uchitomi, Y., Mikami, I., Nagai, K., Nishiwaki, y., Akechi, T., \& Okamura H. (2003). Depression and psychological distress in patients during the year after curative resection of non-small-cell lung cancer. Journal of Clinical Oncology, 21, 69-77.

Zabora, J., Brintzenhofeszoc, K., Curbow, B., Hooker, C., \& Piantadosi, S. (2001). The prevalence of psychological distress by cancer site. Psycho-Oncology, 10, 19-28. 
8.-ANEXOS 
A continuación detallamos las referencias de comunicaciones a congresos y artículos publicados durante la realización de la tesis doctoral, ordenados cronológicamente.

\subsection{1- Comunicaciones orales a congresos}

Costa G. Estudio de la alteración emocional según el estadio del cáncer en una muestra europea. II Congreso Nacional de la Sociedad Española de Psico-Oncología. Murcia, 17 al 19 de Noviembre 2005.

Costa G, Gil F, Salamero M, Sánchez N, Sirgo A. The HADS Cut-Off score in Spanish cancer sample. Psycho-Oncology 2006; 15 (2): S106. International Psycho Oncology Society (IPOS). Venecia, 18 de Octubre 2006.

Costa G. Adaptación Psicológical y Morbilidad psiquiátrica en Cáncer. II Jornada Catalano-Balear de Psico-Oncología. Reus, 17 de Noviembre 2006.

Costa G., Gil F. Calidad de vida en pacientes con cáncer comparado con valores de referencia de la población española. III Congreso Nacional de Psicooncología. Bilbao, 18-20 de Octubre 2007.

Costa G., Gil F. Respuesta cognitiva y crecimiento postraumático durante el primer año de diagnóstico del cáncer. III Congreso Nacional de Psicooncología. Bilbao, 18-20 de Octubre 2007. 
Costa Requena G., Rodríguez Ortega A., Fernández Salillas R., Gil Moncayo FL. Breast Cancer Worry and Distress after the Treatment. J. Psychosomatic Research 2008, 64 (6): S35. XXVI European Conference on Psychosomatic Research. XI Annual Scientific Meetings of the European Association for Consultation-Liaison Psychiatriy and Psychosomatics. XLII Congreso de la Sociedad Española de Medicina Psicosomática. Zaragoza, 25-28 de Junio 2008.

Costa G, Ballester R, Gil F.L. Sintomatología de Estrés Postraumatico en Pacientes con Cáncer. VI Congreso Nacional de la Asociación Española de Psicología Clinica y Psicopatología. Huelva, 27-29 de Noviembre 2008.

Costa Requena G, Ballester R, Gil FL. Diagnostico de trastorno mental y apoyo social percibido en pacientes con cáncer. V Congreso Nacional de la Sociedad Española de Psico-Oncología. Madrid, 4 al 6 Octubre del 2012.

Costa Requena G, Ballester R, Gil FL. Influencia del estilo de afrontamiento y calidad de vida relacionada con la salud en la percepción de apoyo social, durante el tratamiento del cáncer. VI Congreso Nacional de la Sociedad Española de Psico-Oncología. Málaga, 27 al 29 Marzo 2014. 


\subsection{2.- Comunicaciones a congresos formato póster}

Costa-Requena G, Gil Moncayo F. Evaluación de la respuesta adaptativa a la enfermedad oncológica. V Congreso Mundial de Terapias cognitivas y conductuales. Barcelona, 12 de Julio del 2007.

Costa-Requena G, Ortega A, Fernández P, Valverde Y. Quality of Life during Breast Cancer Treatment. Panminerva Medica 2009; 51 S(3): 26. XX world congress on psychosomatic medicine. Turin, 23-26 September 2009.

Costa-Requena G, Ballester R, Gil F. A 1-Year follow-up of posttraumatic stress disorder (PTSD) symptoms and perceived social support in cancer. 15th World Congress of International Psycho Oncology Society (IPOS). Rotterdam, 06 al 08 Noviembre de 2013.

8.1.3.-Relacion de publicaciones derivadas de la tesis

Gil, F., \& Costa-Requena, G. (2005). Aspectos psicológicos relacionados con la cirugía de reducción de riesgo (mastectomía y salpingooroforectomía profiláctica). Psico-oncología, 2 (2-3), 317-328.

Costa-Requena, G., Salamero, M., \& Gil, F. (2007). Validación del cuestionario MOS-SSS de apoyo social en pacientes con cáncer. Medicina Clínica (Barc), 128, 687-691. 
Costa-Requena, G., \& Gil, F. (2007). Crecimiento Postraumático en pacientes oncológicos. Análisis y Modificación de Conducta, 33(148), 229250.

Costa-Requena, G., \& Gi,l F. (2007). Propiedades psicométricas de la escala revisada del impacto del evento estresante (IES-R) en una muestra española de pacientes con cáncer. Análisis y Modificación de Conducta, 33 (149), 311-332.

Costa-Requena, G., \& Gil, F.L. (2008). Respuesta Cognitiva y Crecimiento Postraumático durante el primer año de Diagnóstico del Cáncer. Psicooncología, 5(1), 27-37.

Gil, F., Costa-Requena, G., Salamero, M., Sánchez, N., \& Sirgo, A. (2008). Adaptación psicológica y prevalencia de trastornos mentales en pacientes con cáncer. Medicina Clínica (Barc), 130 (3), 90-92.

Costa-Requena, G., Pérez, X., Salamero, M., \& Gil, F.L. (2009). Discriminación del Malestar Emocional en Pacientes Oncologicos Utilizando la Escala de Ansiedad y Depresion Hospitalaria (HADS). Ansiedad y Estrés, 15 (2-3), 217-229.

Costa-Requena, G., \& Gil, F. (2009). The Mental Adjustment to Cancer scale: A psychometric analysis in Spanish cancer patients. PsychoOncology, 18 (9), 984-991.

Costa-Requena, G., Gil, F. (2009). Quality of Life in the Chemotherapy Treatment of Spanish Cancer Patients: A Comparison of General Population Norms. Psycho-Oncology, 18 (10), 1053-1059. 
Costa-Requena, G., \& Ballester Arnal, R. (2010). Influencia de las características sociodemográficas y clínicas en la calidad de vida y malestar emocional del paciente oncológico. Psico-oncología, 7 (2-3), 453-462.

Costa-Requena, G., \& Gil, F.L. (2010). Posttraumatic Stress Disorder (PTSD) Symptoms in Cancer: Psychometric Analysis of the Spanish PTSD Chechlist-Civilian Version. Psycho-Oncology, 19, 500-507. DOI:10.1002/po. 1601.

Gil, F., Costa-Requena G., \& Pérez, F.J. (2010). Does Chemotherapy reduce stress? Palliative and Supportive Care, 8(4), 455-460. DOI: $10.1017 /$ S1478951510000337.

Costa-Requena, G., \& Ballester Arnal R. (2011). Inicios de la PsicoOncología: Una breve revisión. Cuadernos de Medicina Psicosomática y Psiquiatría de Enlace, 99, 21-28.

Costa-Requena, G., Rodríguez, A., Fernández, R., Palomera, E., \& Gil, F.L. (2011). Cognitive Processing Variables in Breast Cancer: Worry and Distress at the End of Treatment. Journal of Cancer Education, 26 (2), 375379. DOI: 10.1007/s13187-010-01408.

Gil, F., Costa-Requena, G., Hilker, I., \& Benito, L. (2012). First anxiety, afterwards depression: Psychological distress in cancer patients at diagnosis and after medical treatment. Stress and Health, 28, 362-367. DOI: $10.1002 / \mathrm{smi} .2445$ 
Costa-Requena, G., Rodríguez, A., \& Fernández-Ortega, P. (2013). Longitudinal assessment of distress and quality of life in the early stages of breast cancer treatment. Scandinavian Journal of Caring Science, 27, 77-83. doi: 10.1111/j.1471-6712.2012.01003.x

Costa-Requena, G., Ballester Arnal, R., \& Gil, F. (2014). Influence of demographic and clinical variables on perceived social support in cancer patients. Revista de Psicopatología y Psicología Clínica, en prensa. 
8.2.- En el siguiente apartado se muestra el formato publicado de los artículos.

Articulo 1

Costa-Requena G, Ballester Arnal R, Gil F. The influence of coping response and health-related quality of life on perceived social support during cancer treatment: Palliative and Supportive Care 2014; Epub ahead of print. doi:10.1017/S1478951514000418 


\title{
The influence of coping response and health-related quality of life on perceived social support during cancer treatment
}

\author{
GEMA COSTA-REQUENA, M.sc., ${ }^{1}$ RAFAEL BALLESTER ARNAL, PH.D., ${ }^{2}$ AND \\ FRANCISCO GIL, PH.D. ${ }^{3}$ \\ ${ }^{1}$ Department of Psychiatry, Hospital General Universitari Vall d'Hebron, Universitat Autònoma, CIBERSAM, \\ Barcelona, Spain \\ ${ }^{2}$ Department of Basic Psychology, Clinical Psychology and Psychobiology, Jaume I University, Castellon, Spain \\ ${ }^{3}$ Psycho-Oncology Unit, Duran i Reynals Hospital, Barcelona, Spain \\ (RECEIVED February 16, 2014; ACCEPTED March 18, 2014)
}

\begin{abstract}
Objective: In the biopsychosocial approach, perceived social support has served as a protective factor for psychological adjustment to cancer. This study aimed to determine the influence of different coping responses and health-related quality of life (HRQoL) domains on perceived social support during cancer treatment.

Method: A cross-sectional analysis was carried out in a sample of 757 cancer outpatients. The Medical Outcomes Study Social Support Survey (MOS-SSS) was employed to assess perceived social support. The Mental Adjustment to Cancer (MAC) Scale measured coping response, and HRQoL was tested with the Medical Outcomes Study Short Form-36 (SF-36). Multivariate analyses were carried out to examine the extent to which coping and HRQoL were associated with perceived social support.

Results: Coping response explained only $2 \%$ of the variance in perceived social support, but Hopelessness had a significant influence on perceived social support ( $p \leq 0.01$ ). HRQoL, physical, and mental domains made a significant contribution toward perceived social support, accounting for around $10 \%$ of total variance. More than coping response, HRQoL's physical and mental domains had an important influence on perceived social support during cancer treatment.

Significance of Results: The findings of the current study report the importance of HRQoL domains in predicting perceived social support during cancer treatment, emphasizing the holistic and multidisciplinary approach to facilitate adjustment to cancer.
\end{abstract}

KEYWORDS: Perceived social support, Coping style, Health-related quality of life, Cancer treatment

What is of importance to us is the activity and behavior of the total organism or individual as opposed to the activity of single, detachable organs.

- Adolf Meyer (1915; quoted in Karl \& Holland, 2013)

Address correspondence and reprint requests to: Gema CostaRequena, Department of Psychiatry, Hospital General Universitari Vall d'Hebron, Passeig Vall d'Hebron, 119-129, 08034 Barcelona, Spain. E-Mail: gcosta@vhebron.net

\section{INTRODUCTION}

The biopsychosocial model in cancer considers the holistic approach to a patient, and supports a patient's individual treatment. Each cancer patient has their own personal history, with their own social relationships and illness adjustment response within the cancer context (Grassi, 2013). The conceptual model of biopsychosocial processes can be reported in three main domains: (1) physical well-being, which refers to disease-specific symptoms or the side effects 
of treatment; (2) psychological well-being, referring to emotional and spiritual aspects, communication, cognition, coping style, subjective meaning of the cancer, and personal accomplishment; and (3) interpersonal well-being, which refers to perceived social support and social role functioning. Adjustment to cancer has been defined as the cognitive and adaptive behavioral mechanism that takes place over time, within their social setting (Brennan, 2001). One way of capturing patients' adjustment response to cancer is using health-related quality of life (HRQoL) measures. The HRQoL instruments have been shown to be adequate for measuring change over time in adjustment responses to cancer (Brennan, 2001). Traditionally, HRQoL was considered a multidimensional concept, including patients' subjective evaluation of their physical function, disease, and treatment-related symptoms, and psychological and social functioning (Ganz, 1994).

The relationship between HRQoL and social support is best understood using stress-buffering hypotheses, where social support improves HRQoL by facilitating an adaptive coping response (Helgeson, 2003). Additionally, in the integrative research model on psychosocial oncology, social support and coping response were among some of the psychosocial variables considered for mediating adjustment to cancer, HRQoL being the outcome variable for an adaptive response to cancer (Holland, 2002). Many studies have examined the predictive nature of social support by diminishing psychological comorbidity in cancer patients and survivors (Devine et al., 2003; Helgeson \& Cohen, 1996) and noted that a higher level of social integration was associated with better HRQoL (Michael et al., 2002; Lewis et al., 2001). The results showed that especially social support demonstrated its moderating effects on cognitive-processing variables, such as intrusive thoughts about cancer (Lewis et al., 2001). Social support enabled patients to garner additional coping resources that facilitated emotional processing of their cancer experience through verbal disclosure of thoughts and feelings (Devine et al., 2003; Lepore \& Helgeson, 1998; Zakowski et al., 2004). While many studies substantiated that perceived social support has been considered a significant mediator of psychological outcomes in cancer patients (Holland, 2002; Helgeson \& Cohen, 1996), the odd study has suggested that social support has no mediating effect on psychological well-being and that other personal resources like optimism or self-transcendence should be included (Mathews \& Cook, 2009). Moreover, specifically in the context of a cancer-screening setting, psychological well-being is influenced by social constraint and cognitive adaptation to a threatening event, rather than perceived social support or emotional processing (Andrykowski \& Pavlik, 2011).
Helgeson et al. (2004) examined patterns of adjustment to breast cancer over a four-year period, where social support was distinguished from the different mental functions, illustrating that women who experienced decline in mental health also had fewer social resources. Regarding the functional aspects of social support relating to mental and physical well-being, it was suggested that patients' psychological resources affect their ability to utilize social support to improve personal physical wellbeing (Bloom et al., 2001). Perceived social support, measured as an outcome variable, has been related to psychological processes of supportive relational schemas, coping responses, or personality factors (Uchino, 2009; den Oudsten et al., 2010).

An important line of inquiry in adjustment to cancer is defined by the combined effect of coping response, social support, and HRQoL. Considering three previous dimensions conceptualized in the biopsychosocial approach to cancer, our study was focused to highlight the contributions of underlying factors affecting perceived social support in cancer patients. Our objective was to assess the influence of the combined contribution of different types of coping responses and HRQoL domains in predicting perceived social support during cancer treatment. It was hypothesized that perceived social support was related to patients' coping responses, at the same time as it was influenced by their HRQoL, physical, and mental domains.

\section{METHODS}

\section{Sample/Participants}

Our study was conducted at a cancer center. The inclusion criteria were: confirmed diagnosis of cancer; outpatients undergoing chemotherapy and radiotherapy or other oncology treatment; and patients $18-80$ years of age. Patients with a low performance status (Karnofsky Index $<40 \%$ ), psychotic illness, or significant cognitive impairment were excluded. The study was approved by an institutional research board and an ethics committee review.

\section{Measurements}

A demographic questionnaire collected data about patients' sociodemographic characteristics and medical status. To measure coping response, the Mental Adjustment to Cancer (MAC) Scale was utilized. This is a 40-item self-rating questionnaire that employs a 4point Likert-type scale that includes five behavioral styles (Watson et al., 1988; Ferrero et al., 1994), these being Fighting Spirit, Helpless-Hopelessness, Anxious Preoccupation, Fatalism, and Avoidance 
(Denial). In the Spanish version of the MAC, which contained 28 items, the appropriate factor solutions also constituted five factors that accounted for $36.69 \%$ of total variance. The resulting factors were then titled as follows: Hopeless $(\alpha=0.78)$, Anxious $(\alpha=0.74)$, Resignation/Fatalism $(\alpha=0.62)$, Illness Acceptance $(\alpha=0.44)$, and Self-Safety Behavior $(\alpha=0.69)$, with acceptable internal consistency in the majority of dimensions (Costa-Requena \& Gil, 2009).

A general measure of HRQoL was provided by the Medical Outcomes Study, Short Form-36 (SF-36) (Ware \& Sherbourne, 1992). This instrument measured two general health domains-physical health and mental health-divided by eight specific domains: physical functioning, limitations in performing roles because of physical health problems (physical roles), bodily pain, general health, vitality, social functioning, limitations in performing roles because of emotional health problems (emotional roles), and mental health. In each domain of the $\mathrm{SF}-36$ scale, scores range from 0 (the worst possible measured health) to 100 (the best possible measured health). Hence, higher scores represented better functioning. The SF -36 health survey was translated and adapted into Spanish, and this version has shown satisfactory reliability, with a Cronbach's alpha ranging from 0.71 to 0.94 for all dimensions (Alonso et al., 1995).

Social support was assessed with the Medical Outcomes Study Social Support Survey (MOS-SSS) (Sherbourne \& Stewart, 1991). This questionnaire measures five functional aspects of the perceived availability of social support (Emotional, Informational, Instrumental, and Affective Support, and Positive Interaction). For each item, the respondent was asked to indicate how often each support was available to them, if necessary. All but one item (number of close friends or relatives) were scored on a 5-point Likert-type scale ranging from 1 (none of the time) to 5 (all of the time). For each subscale, simple algebraic sums were computed, with a higher score indicating a better perception of social support. Adequate psychometric properties of the MOS-SSS have been established with Spanish validity and a Cronbach's alpha of 0.94 (Costa-Requena et al., 2007). By using a factor analysis in Spanish cancer patients, three subscales of functional social support were distinguished: emotional/informational support, affective support, and instrumental support. Additionally, the total index of functional items was used as an overall measure of support (Sherbourne \& Stewart, 1991; Costa-Requena et al., 2007).

\section{Procedure}

With consecutive sampling, the samples were gathered from patients who had undergone oncology treatment, mainly with chemotherapy or a combination of chemotherapy with radiotherapy. Participants were recruited in the outpatient clinic while waiting for medical examination or chemotherapy treatment. All patients approached were informed of the objective of this study when asked to fill out the sociodemographic data and before signing the consent form agreeing to participate in the study. Data collection was conducted in a private area adjacent to the hospital ward. Permission to conduct the study was received from the institutional review board of the hospital. Patients were first registered with a structured interview by a clinical psychologist to obtain sociodemographic data and a Karnofsky functional index; medical characteristics were available from the patient's clinical record. Following this sociodemographic interview, patients were asked to complete the MAC, SF-36, and MOS-SSS questionnaires. Participants were asked to fill them out by themselves, with an interviewer available for questions at all times. The assessment protocol lasted from 20 to 45 minutes.

\section{Statistical Analysis}

The demographic and clinical-related characteristics of the sample were examined using descriptive statistics. An analysis of variance was performed, which yielded Pearson's product-moment correlation coefficients to evaluate the association of different types of coping styles and two general HRQoL domainsphysical health and mental health-with a global index of perceived social support. Then, to test the theoretical model of influence of coping response on perceived social support, two standard least-squares regression analyses were developed with significant correlations. In both cases, the global index of perceived social support was a dependent variable. Coping variables significantly correlated with perceived social support used in regression models. In the first model, only different types of coping response were utilized as predicting variables, while in the second the two general health domains were added as independent variables. Multicollinearity was calculated by a variation inflation factor (VIF) in the regression analyses. Inspection of residuals revealed whether the distribution could be considered fairly normal. Analyses were carried out using the Statistical Package for Social Sciences (SPSS, version 15.0).

\section{RESULTS}

\section{Subjects}

The interviewer originally approached 823 patients to participate in the study, and a total of $757(91.9 \%)$ 
completed the sociodemographic interview. The main reasons for refusal were lack of time $(n=39)$, withdrawal without explanation $(n=12)$, disinterest in the study $(n=7)$, and not feeling well $(n=\mathrm{s} 8)$.

The median age of the sample population was 55 years; 371 were men $(49 \%)$. Most of the patients $(569,75.4 \%)$ were married or had a partner. The sample represented many different types of cancer, the most prevalent being breast, colorectal, and respiratory tumors. At the time of the study, 665 patients $(88,4 \%)$ were undergoing chemotherapy. Almost half the patients $(347,46.2 \%)$ showed almost no symptoms of impairment. A summary of the clinical and sociodemographic characteristics can be found in Table 1.

\section{Perceived Social Support Correlations}

In bivariate correlation analyses, a higher level of perceived social support was significantly related to better the HRQoL physical component $(r=0.08, p \leq$ $0.05)$ and the HRQoL mental component $(r=0.28$, $p \leq 0.01$ ). Moreover, there was a negative association between perceived social support and coping response to cancer, that is, perceived social support was related with less Resignation $(r=-0.07, p \leq 0.05)$, less Hopelessness $(r=-0.13, p \leq 0.01)$, and lower scores on Anxiety response to illness $(r=-0.09, p \leq 0.05)$. Coping response with Illness Acceptance and SelfSafety Behavior did not have a significant association with perceived social support. These correlations are presented in Table 2.

\section{Influence of Type of Coping Response and HRQoL on Perceived Social Support}

In the first model, a standard regression analysis was calculated with significant bivariate correlations to identify the coping responses that influenced patients' perceived social support. In the second model, HRQoL domains were added with coping responses to assess their contributions to perceived social support. In collinearity diagnostics, the VIF for predictors ranged from 1.01 to 1.14 , indicating multicollinearity did not affect the estimated $\beta$ parameter.

Three coping responses were added: Resignation, Hopelessness, and Anxiety. The previous model reported an acceptable statistical analysis $(F=4.50, p \leq$ 0.01 ), and the total equation was significant, but only accounted for $1.5 \%$ of the variance. Hopelessness, with a negative coefficient, had a significant influence on perceived social support, as can be seen from Table 3 . The second model in the regression analyses added the physical and mental components of HRQoL with coping response, and these variables improved the model's fitness to explain perceived social support $(F=14.88, p \leq 0.01)$. The total equation accounted for
Table 1. Clinical and demographic data $(N=757)$

\begin{tabular}{lrc}
\hline \hline Mean age (SD) & \multicolumn{2}{c}{$53.5(11.7)$} \\
Median & \multicolumn{2}{c}{55} \\
Mode & 59 \\
Gender & $n$ & $\%$ \\
Male & 371 & 49 \\
Female & 386 & 51 \\
Partner situation & & \\
Married/partnered & 569 & 75.4 \\
Single & 80 & 10.6 \\
Divorced /separated & 58 & 7.7 \\
Widowed & 48 & 6.4 \\
Education level & & \\
Primary & 413 & 54.7 \\
High school & 295 & 39 \\
University & 47 & 6.3 \\
Personal psychiatric antecedent & 177 & 23.4 \\
Family history of cancer & 445 & 58.9 \\
Family death from cancer & 339 & 44.8 \\
Karnofsy Index & & \\
Normal activity (100-90) & 201 & 27 \\
Hardly any symptoms of impairment $(80)$ & 347 & 46.2 \\
Some symptoms of impairment (70-50) & 197 & 26.7 \\
Time since diagnosis (months) & & \\
1-3 & 250 & 33.1 \\
4-7 & 215 & 28.5 \\
8-11 & 69 & 9.1 \\
12 or more & 221 & 29.3 \\
Tumor stage & & \\
Localized & 220 & 29.3 \\
Regional & 242 & 32.2 \\
Metastasis & 167 & 22.2 \\
Not solid tumor & 122 & 16.2 \\
Tumor site & & \\
Breast & 168 & 22.2 \\
Gastrointestinal & 162 & 21.4 \\
Respiratory & 146 & 19.3 \\
Genitourinary & 111 & 14.7 \\
Not solid tumors & 123 & 16.3 \\
Other solid tumors & 46 & 6.1 \\
Oncology treatment & & \\
Surgery & 425 & 57.5 \\
Adjuvant chemotherapy & 663 & 88.4 \\
Adjuvant radiotherapy & 242 & 32.8 \\
Hormonal treatment & 57 & 7.8 \\
Other & 36 & 4.8 \\
& & \\
\hline \hline & & \\
\hline
\end{tabular}

$9 \%$ of the variance. More than coping response, HRQoL's domains were significant predictors of perceived social support, particularly the mental component. The Hopelessness response failed to be significant when HRQoL's domains were added. The contribution of each predictor on the global index of perceived social support was demonstrated by a partial correlation, as presented in Table 3 .

\section{DISCUSSION}

Considering the biopsychosocial dimensions in the approach to cancer, social support has a significant role 
Table 2. Correlations between perceived social support, coping style, and HRQoL domains

\begin{tabular}{|c|c|c|c|c|c|c|c|}
\hline 1. Social support & - & & & & & & \\
\hline 2. Resignation & $-0.07^{\mathrm{a}}$ & - & & & & & \\
\hline 4. Anxiety & $-0.09^{\mathrm{a}}$ & $0.29^{\mathrm{b}}$ & 0.24 & - & & & \\
\hline 5. Acceptance illness & 0.05 & 0.01 & 0.06 & $0.12^{b}$ & - & & \\
\hline 6. Self-safety behavior & 0.05 & 0.06 & -0.04 & 0.05 & $0.17^{\mathrm{b}}$ & - & \\
\hline 8. HRQoL mental & $0.28^{b}$ & -0.02 & $-0.20^{b}$ & $-0.15^{b}$ & 0.02 & $0.07^{\mathrm{a}}$ & 0.01 \\
\hline
\end{tabular}

${ }^{a} p \leq 0.05$.

${ }^{b} p \leq 0.01$.

to play regarding psychological adjustment to cancer (Helgeson et al., 2004). In order to better understand the mechanisms affecting perceived social support in cancer patients, the current study examined the relative factors associated with it. Social support was not considered simply an aspect of HRQoL, but it has been shown to effectively improve HRQoL in cancer patients (Bloom et al., 2001; Sherbourne \& Stewart, 1991). This could be a determining variable in a reciprocal relationship. Our results suggest that better HRQoL mental and physical domains indicate better perceived social support during cancer treatment. The mental component of HRQoL was especially relevant in influencing perceived social support. Moreover, in other studies, a higher level of perceived social support influenced better mental HRQoL by facilitating cognitive processing to reduce distress (Andrykowski \& Pavlik, 2011).

The earliest studies showed a relationship between patient psychological response and adjustment to a diagnosis of cancer (Greer et al., 1979). Coping responses measured after cancer diagnosis predicted adjustment over a three-year follow-up (Hack \& Degenr, 2004). Particularly, the Hopelessness response was associated with poor psychological adjustment (Schnoll et al., 1995; Shimizu et al., 2012); furthermore, at 10 years post-diagnosis, cancer patients' survival decreased after a high initial Hopelessness response (Hack \& Degenr, 2004; Watson et al., 2005). Also, it has been found that coping strategies and cognitive variables may influence perceived social support (den Oudsten et al., 2010; Uchino, 2009). Current findings showed that a Hopelessness coping response is a negative determinant of patients' perceived social support. This became clear when the Hopelessness response was considered a cognitive indicator with low positive effects (Beck et al., 2001). In turn, other studies have shown that perceived social support is not a predictor of a Hopelessness response in adjustment to cancer, but it does predict other positive coping responses, such as Fighting Spirit (Cicero et al., 2009).

Also noteworthy in our results is the fact that, when HRQoL domains were added to evaluate

Table 3. Standardized regression analysis of overall global index of perceived social support

\begin{tabular}{|c|c|c|c|c|c|}
\hline \multirow{2}{*}{ Variables } & \multicolumn{5}{|c|}{ Perceived Social Support } \\
\hline & $\overline{\Delta R^{2}}$ & $\begin{array}{c}\text { Standardized } \\
\text { Beta }\end{array}$ & $t$ & $p$ & $\begin{array}{c}\text { Partial } \\
\text { Correlation }\end{array}$ \\
\hline \multicolumn{6}{|l|}{ Model 1} \\
\hline Resignation & & -0.05 & -1.49 & 0.13 & -0.05 \\
\hline Hopeless & & -0.11 & -2.96 & 0.00 & -0.11 \\
\hline Anxiety & & 0.00 & 0.04 & 0.96 & 0.00 \\
\hline & 0.01 & & & 0.00 & \\
\hline \multicolumn{6}{|l|}{ Model 2} \\
\hline Resignation & & -0.06 & -1.65 & 0.09 & -0.06 \\
\hline Hopeless & & -0.05 & -1.48 & 0.13 & -0.05 \\
\hline Anxiety & & 0.03 & 0.81 & 0.41 & 0.03 \\
\hline HRQLL physical component & & 0.09 & 2.57 & 0.01 & 0.09 \\
\hline \multirow{2}{*}{ HRQoL mental component } & & 0.27 & 7.29 & 0.00 & 0.26 \\
\hline & 0.09 & & & 0.00 & \\
\hline
\end{tabular}


patients' perceived social support, coping response was not significant. These findings paralleled the results described in other studies, where HRQoL domains were stronger predictors rather than coping behavior for patients' perceived psychosocial support needs (Brix et al., 2008). Positive health outcomes, with a reduction in treatment side effects, might gradually diminish physical deterioration related to cancer, thus ensuring recovery.

Our study had some limitations. First, the sample was taken from patients enrolled in only one hospital, reducing any ability to generalize. Second, the crosssectional design did not clarify a causal interpretation of the association between coping style and HRQoL domains regarding perceived social support. In future studies, it would be interesting to explore longitudinally the effect of changes in coping responses and HRQoL domains on perceived social support over time. Third, patients' sociodemographic and clinical variables were not analyzed, including personality traits or personal resources such us optimism and self-esteem, and these could have an impact on psychological distress and perceived social support. Finally, contribution of coping response and HRQOL to different functional dimensions of perceived social support were also not analyzed. This would strengthen differential specific effects on outcomes.

The interest in perceived social support has been reported within the integrative research model of psychosocial oncology (Holland, 2002) and following the early biopsychosocial principles in the approach to cancer. Both support the need for an individualized doctor-patient communication, attending to the patients' psychosocial aspects and interpersonal relations (Alonso, 2004; Grassi, 2013). The current findings emphasize the importance of HRQoL domains in predicting perceived social support during cancer treatment. In this way, improvements in cancer treatment to facilitate patients' HRQoL also provides psychological well-being. It is therefore essential to consider a holistic and multidisciplinary approach to facilitate adjustment to cancer. Along these lines, following cancer diagnosis and treatment, a higher level of perceived social support in cancer survivors has been associated with greater likelihood of change toward healthy behaviors (Harper et al., 2007). Undoubtedly, in the health practice areas there is a wide range of factors influencing healthcare and the healing process, including psychological and social factors, and not only biomedical management (Alonso, 2004; Grassi, 2013).

\section{CONFLICTS OF INTEREST}

The authors have no funding or conflicts of interest to disclose.

\section{REFERENCES}

Alonso, J., Prieto, L. \& Antó, J.M. (1995). La versión espanola del SF-36 Health Survey (Cuestionario de Salud SF-36): Un instrumento para la medida de los resultados. Medicina Clinica (Barcelona), 104, 771-776.

Alonso, Y. (2004). The biopsychosocial model in medical research: The evolution of the health concept over the last two decades. Patient Education and Counseling, 4, 239-244.

Andrykowski, M.A. \& Pavlik, E.J. (2011). Response to an abnormal ovarian cancer-screening test result: Test of the social cognitive processing and cognitive social health information processing models. Psychology \& Health, 26(4), 383-397.

Beck, R., Perkins, T.S., Holder, R., et al. (2001). The cognitive and emotional phenomenology of depression and anxiety: Are worry and hopelessness the cognitive correlates of NA and PA. Cognitive Therapy Research, 25(6), $829-838$

Bloom, J.R., Stewart, S.L., Johston, M., et al. (2001). Sources of support and the physical and mental well-being of young women with breast cancer. Social Science \& Medicine, 53, 1513-1524.

Brennan, J. (2001). Adjustment to eancer-eoping or personal transition? Psycho-Oncology, 10, 1-10.

Brix, C., Schleussner, C., Füller, J., et al. (2008). The need for psychosocial support and its determinants in a sample of patients undergoing radiooncological treatment of cancer. Journal of Psychosomatic Research, $65,541-548$.

Cicero, V., Lo Coco, G., Gullo, S., et al. (2009). The role of attachment dimensions and perceived social support in predicting adjustment to cancer. Psycho-Oncology, 18, 1045-1052.

Costa-Requena, G. \& Gil, F. (2009). The Mental Adjustment to Cancer Scale: A psychometric analysis in Spanish cancer patients. Psycho-Oncology, 18, 984-991.

Costa-Requena, G., Salamero, M. \& Gil, F. (2007). Validación del cuestionario MOS-SSS de apoyo social en pacientes con cáncer. Medicina Clinica (Barcelona), 128, $687-691$.

den Oudsten, B.L., Van Heck, G.L., Van der Steeg, A.F.W., et al. (2010). Personality predicts perceived availability of social support and satisfaction with social support in women with early stage breast cancer. Supportive Care in Cancer, 18, 499-508.

Devine, D., Parker, P.A., Fouladi, R.T., et al. (2003). The association between social support, intrusive thoughts, avoidance, and adjustment following an experimental cancer treatment. Psycho-Oncology, 12, 453-462.

Ferrero, J., Barreto, M.P. \& Toledo, M. (1994). Mental adjustment to cancer and quality of life in breast cancer patients: An exploratory study. Psycho-Oncology, 3, 223-232.

Ganz, P.A. (1994). Quality of life and the patient with cancer. Cancer, 74(4), 1445-1452.

Grassi, L. (2013). Quam bene vivas referre: Curing and caring in psycho-oncology. Psycho-Oncology, 22, 1679-1687.

Greer, S., Morris, T. \& Pettingale, K.W. (1979). Psychological response to breast eancer: Effect on outcome. Lancet, $i, 785-787$.

Hack, T.F. \& Degenr, L.F. (2004). Coping response following breast cancer diagnosis predict psychological adjustment three years later. Psycho-Oncology, 13, 235-247.

Harper, F.W.K., Schmidt, J.E., Beacham, A.O., et al. (2007). The role of social cognitive processing theory and 
optimism in positive psychosocial and physical behavior change after cancer diagnosis and treatment. PsychoOncology, 16, 79-91.

Helgeson, V.S. (2003) Social support and quality of life. Quality of Life Research, 12(Suppl. 1), 25-31.

Helgeson, V.S. \& Cohen, S. (1996). Social support and adjustment to cancer: Reconciling deseriptive, correlational, and intervention research. Health Psychology, 15(2), 135-148.

Helgeson, V.S., Snyder, P. \& Seltman, H. (2004). Psychological and physical adjustment to breast cancer over 4 years: Identifying distinct trajectories of change. Health Psychology, 23, 3-15.

Holland, J.C. (2002). History of psycho-oncology: Overcoming attitudinal and conceptual barriers. Psychosomatic Medicine, 64, 206-221.

Karl, S.R. \& Holland, J.C. (2013). Looking at the roots of psychosomatic medicine: Adolf Meyer. Psychosomatics, $54,111-114$.

Lepore, S.J. \& Helgeson, V.S. (1998). Social constraints, intrusive thoughts, and mental health after prostate cancer. Journal of Social and Clinical Psychology, 17(1), 89-106.

Lewis, J.A., Manne, S.L., DuHamel, N., et al. (2001). Social support, intrusive thoughts, and quality of life in breast cancer survivors. Journal of Behavioral Medicine, 24(3), $231-245$

Mathews, E.E. \& Cook, P.F. (2009). Relationships among optimism, well-being, self-transcendence, coping, and social support in women during treatment for breast eancer. Psycho-Oncology, 18, 716-726.

Michael, Y.L., Berkman, L.F., Colditzm, G.A., et al. (2002). Social networks and health-related quality of life in breast eancer survivors: A prospective study. Journal of Psychosomatic Research, 52, 285-293.

Schnoll, R.A., Mackinnon, J.R., Stolbach, L., et al. (1995)

The relationship between emotional adjustment and two factor structures of the Mental Adjustment to Cancer (MAC) Scale. Psycho-Oncology, 4, 265-272.

Sherbourne, C.D. \& Stewart, A.L. (1991). The MOS Social Support Survey. Social Science \& Medicine, 32, $705-714$.

Shimizu, K., Nakaya, N., Saito-Nakaya, K., et al. (2012). Clinical biopsychosocial risk factors for depression in lung cancer patients: A comprehensive analysis using data from the Lung Cancer Database Project. Annals of Oncology, 23, 1973-1979.

Uehino, B.N. (2009). What a lifespan approach might tell us about why distinct measures of social support have differential links to physical health. Journal of Social and Personal Relationship, 26(1), 53-62.

Ware, JR \& Sherbourne, C.D. (1992). The MOS 36-item short-form health survey (SF-36). Medical Care, $30(6), 473-481$.

Watson, M., Greer, S., Young, J., et al. (1988). Development of a questionnaire measure of adjustment to cancer: The MAC Scale. Psychological Medicine, 18, 203-209.

Watson, M., Homewood, J., Haviland, J., et al. (2005). Influence of psychological response on breast cancer survival: Ten-year follow-up of a population-based cohort. European Journal of Cancer, 41, 1710-1714.

Zakowski, S.G., Ramatim, A., Mortonm, C., et al. (2004). Written emotional diselosure buffers the effects of social constraints on distress among cancer patients. Health Psychology, 23(6), 555-563. 
Articulo 2

Costa-Requena G, Ballester Arnal R, Gil F. Perceived Social Support in Spanish Cancer Outpatients with Psychiatric Disorder. Stress Health 2013; 29: 421-426. 


\title{
RESEARCH ARTICLE \\ Perceived Social Support in Spanish Cancer Outpatients with Psychiatric Disorder
}

\author{
Gema Costa-Requena ${ }^{1 *{ }^{\dagger}}$, Rafael Ballester Arnal ${ }^{2}$ \& Francisco Gil ${ }^{3}$ \\ 'Clinical Psychology, Department of Psychiatry, Hospital Universitari Vall d'Hebron, Universitat Autonoma de Barcelona, CIBERSAM, \\ Barcelona, Spain \\ ${ }^{2}$ Department of Basic Psychology, Clinical psychology and Psychobiology, Universitat Jaume I, Castellon, Spain \\ ${ }^{3}$ sycho-oncology Unit, Hospital Duran i Reynals, Barcelona, Spain
}

\begin{abstract}
This study examines differences in perceived social support during oncology treatment of cancer patients, whilst taking into account the presence of psychiatric disorder. Of particular interest were cancer patients who received psychopharmacology treatment compared with those who did not. A total of 760 cancer outpatients were recruited from one hospital in Spain. Multivariate analysis of variance with the general linear model procedure was used. The Medical Outcomes Study Social Support Survey was used to assess social support perceived. The Diagnostic Interview Schedule using DSM-III-R criteria was utilized for the diagnosis of psychiatric disorders. There were significant differences between the patients diagnosed with a psychiatric disorder and those not diagnosed with psychiatric disorders in terms of perceived Emotional/Informational Support $(F=19.11, p<0.01)$, Affectionate Support $(F=12.30$, $p<0.01)$ and the Overall Support Index $(F=16.73, p<0.01)$. In patients requiring psychopharmacology treatment, significant differences were presented with Structural Support $(F=4.32, p<0.05)$, Emotional/Informational Support perceived $(F=7.87, p<0.01)$, Instrumental Support $(F=4.17, p<0.05)$ and Overall Support Index $(F=7.84$, $p<0.01)$. Psychopharmacology treatment helped to increase the perception of social support received by the patient. Healthcare professionals could provide support that would normalize cancer patients' distress, taking into account the importance of perceived social support for the psychological well-being of patients. Copyright $\oplus 2013$ John Wiley \& Sons, Ltd.
\end{abstract}

Received 18 October 2012; Revised 15 January 2013; Accepted 23 January 2013

Keywords

social support; cancer; distress; psychiatric disorder; psychopharmacology treatment

*Correspondence

Gema Costa-Requena, Department of Psychiatry, Hospital Universitari Vall d'Hehron, Passeig Vall d'Hehron, 119-129, 08035 Barcelona, Spain.

tEmail: gcosta@ whebron net

Published online 25 February 2013 in Wiley Online Library (wileyonlinelibrary.com) DOI: $10.1002 / 5 m i .2488$

\section{Introduction}

Social support is considered a multidimensional concept that includes structural support or the quantity of social ties that the personal network consists of. Functional social support is measured by a person's assessment of the meaningfulness of interpersonal relationships. The dimensions of functional support can involve instrumental assistance, sharing information about cancer or treatment, as well as cancer's emotional involvement or affective support (Sherbourne \& Stewart, 1991).

The extensive body of the literature about the prevalence of psychological distress in cancer patients produced mixed results. Previous studies had estimated rates of clinically significant distress ranging between $29 \%$ and $43 \%$ Zabora, Brintzenhofeszoc, Curbow,
Hooker, and Piantadosi (2001). The variability across studies using formal psychiatric diagnosis criteria contributes to a wider range of psychiatric disorder, which has been estimated to be between $6 \%$ and $45 \%$ for cancer outpatients (Culha et al., 2004; Gil et al., 2008; Kissane et al., 2004). Adjustment disorders, characterized by the presence of either an anxious or depressed mood, or a mixture of both, are likely to be visible during the course of oncology treatment or cancer trajectory (Bringmann et al., 2008; Gil et al., 2008; Kissane et al., 2004). Predictors of psychiatric morbidity after cancer diagnosis had been given showed low social support, physical functioning deteriorating, sociodemographic variables, metastases or complications of disease (Bringmann et al., 2008; Parker, Baile, Moor, \& Cohen, 2003). In psychosocial adjustment to cancer, it has been reported how psychiatric morbidity in 
cancer patients was negatively associated with patient's health-related quality of life (Devine, Parker, Fouladi, \& Cohen, 2003; Parker et al., 2003).

Social support may buffer some of the negative effects of life-threatening illness by mitigating distress symptoms and by enabling individuals to garner additional coping resources (Akechi, Okamura, Yamawaki, \& Uchitomi, 1998; Devine et al., 2003; Helgeson \& McUmber, 2010; Kornblith et al., 2001). Others findings have suggested evidence of a relationship between poor perceived social support and high levels of psychological distress (Devine et al., 2003; Helgeson \& McUmber, 2010). Moreover, increased levels of distress were associated with a worse quality of life (Zabora et al., 2001). Finally, studies have provided evidence that a lowered perception of social support influences subsequent levels of distress; thus, higher levels of distress may also tend to erode survivors' social support over time These higher levels of distress during and after treatment for breast cancer were associated with decreased survivors' perceptions of instrumental and emotional support from the partner (Helgeson, Snyder, \& Seltman, 2004; Talley, Molix, Schlegel, \& Bettencourt, 2010).

Social support was shown to be an important component in a patient's psychological adjustment to cancer (Akechi et al., 1998; Helgeson \& McUmber, 2010), health-related quality of life (Helgeson \& McUmber, 2010; Parker et al., 2003) and, more so, their survival from cancer (Helgeson et al., 2004; Kroenke, Kubzansky, Schernhammer, Holmes, \& Kawachi, 2006). The aim of this study was to assess differences in the distinguished dimensions of perceived social support among cancer outpatients diagnosed with a psychiatric disorder compared with those patients not diagnosed with a psychiatric disorder. Second, patients who were receiving psychopharmacological treatment were compared with those who were not required to receive treatment.

\section{Methods}

\section{Sample/participants}

The study was conducted at the Duran i Reynals hospital, an oncology centre in Barcelona (Spain). The inclusion criteria were patients with a cancer diagnosis, outpatients who were currently receiving chemotherapy and radiotherapy or other oncology treatment and patients who were aged between 18 and 80 years old. Patients with a low performance status (Karnofsky $40 \%$ ) or who had a psychotic illness or significant cognitive impairment were excluded. The study was approved by the Institutional Research Board and obtained Ethics Committee Review of the hospital.

\section{Measurements}

A questionnaire collected data about the patient's socio-demographic characteristics and medical status.

Functional status of oncology patients was evaluated by the Karnofsky Performance Scale (Karnofsky,
Albelman, Craver, and Burchenal 1948), an index rated from 0 to 100 in steps of 10 , with low scores reflecting high impairment in normal activity and self-care.

Psychological distress was assessed using the Hospital Anxiety and Depression Scale (HADS, Zigmond \& Snaith, 1983) which is a 14-item instrument with two dimensions, depression and anxiety (seven items for each); in this study, the total HADS score has been utilized. Each item is rated on a four-point scale from 0 to 3 . The HADS has been previously validated and has good internal consistency with the Spanish population (Cronbach's $\alpha$ of 0.86 for anxiety and 0.86 for depression) (Quintana et al., 2003).

In order to diagnose psychiatric disorders, the clinical interview was used. The Diagnostic Interview Schedule (DIS-I) (Spitzer, 1983) Spanish version was adapted from DSM-III-R criteria. A clinical psychologist was trained in order to standardize interviews and to use the diagnosis criteria.

Social Support was assessed with the Medical Outcomes Study Social Support Survey (MOS-SSS) (Sherbourne \& Stewart, 1991). This questionnaire measured five functional aspects of the perceived availability of social support (emotional support, informational support, instrumental support, affectionate support and positive interaction). For each item, the respondent was asked to indicate how often each support was available to them if needed. All but one item (i.e. number of close friends or relatives) are scored on a five-point Likert scale ranging from 1 (none of the time) to 5 (all of the time). For each subscale, simple algebraic sums were computed, with a higher score indicating a better perception of social support. The first item of the questionnaire measured structural support, which relates to the number of close friends and close relatives who provided support to the patient. Adequate psychometric properties of MOS-SSS have been established in Spanish validity, Cronbach's $\alpha 0.94$ Costa-Requena, Salamero, and Gil (2007). By using a factor analysis in Spanish oncology patients, three subscales of functional social support were distinguished: emotional/informational support, affectionate support and instrumental support (Costa-Requena et al., 2007).

\section{Procedure}

The sample was selected consecutively from patients who had undergone oncology treatment. Participants were recruited in the hospital ward while they were waiting for a medical examination or chemotherapy treatment, and they were informed about the objective of this study. Patients who accepted to participate in the study were asked to sign the consent form and then were shown to a private area adjacent to the hospital ward to be interviewed. The patients were first assessed in a structured interview to obtain socio-demographic data; patients' Karnofsky functional index was rated by their clinical nurse, whilst other medical characteristics were available from each patient's clinical record. 
After this, patients were asked to complete a screening test used to assess psychological distress, the HADS and the social support instrument, MOS-SSS. In HADS, the cut-off score for the screening of adjustment disorders was more than 13 Razavi, Delvaux, Farvacques, and Robaye (1990). Patients who scored 14 or higher on the HADS scale went through the psychiatric interview DIS-I. In a subgroup of patients who scored less than 14 (one in four patients), some were randomly interviewed using the DIS-I to validate the results obtained with the HADS, suggesting presence of psychiatric disorders. Participants were asked to fill out the questionnaire themselves with an interviewer available for questions at all times. The assessment protocol lasted 25 to $60 \mathrm{~min}$.

\section{Statistical analysis}

Demographic and clinical-related characteristics of the sample were examined using descriptive statistics. Multivariate analysis of covariance using the general linear model (GLM) multivariate procedure was undertaken. This can be particularly interesting when there are unequal numbers of observations across factor-level combinations. Socio-demographic variables such age, gender, family status and employed conditions were included as covariates. Normal distributed data were checked with Kolmogorov-Smirnov test, and homogeneity of variance was verified. GLM multivariate analysis was calculated to evaluate the association of the three functional dimensions of the perceived social support as dependent variables, with diagnosis of psychiatric disease and psychopharmacology treatment as an independent variable. Statistical significance was controlled using a restrictive alpha level of 0.01 . Analyses were carried out using the Statistical Package for Social Sciences (SPSS version 15.0).

\section{Results}

\section{Participants}

The interviewer originally approached 832 patients to participate in this study, but a total of $760(91.3 \%)$ patients finally completed all questionnaires and the socio-demographic interview. The main reasons for not filling in the questionnaire were lack of time $(n=43)$, withdrew without explanation $(n=13)$, a disinterest in the study $(n=8)$ or not feeling well $(n=8)$.

In the sample, median age was 55 years, and there were 372 men ( $48.9 \%$ ). The sample represented many different types of cancer, the most prevalent being breast, colorectal and respiratory tumour. At the time of the study, 665 patients (88.3\%) were undergoing chemotherapy, A considerable proportion of patients $(259,34.4 \%)$ required psychopharmacology treatment; these were mainly anxiolytics, tricyclic antidepressants or hypnotics. The summary of clinical and sociodemographic characteristics can be found in Table I.
Table I. Clinical and demographic data $(n=760)$

\begin{tabular}{|c|c|c|}
\hline Mean age $(S D)$ & \multicolumn{2}{|c|}{$53.5(11,7)$} \\
\hline Mode & \multicolumn{2}{|c|}{59} \\
\hline Gender & $n$ & $\%$ \\
\hline Men & 372 & 48.9 \\
\hline Women & 388 & 51.1 \\
\hline \multicolumn{3}{|l|}{ Partner situation } \\
\hline Married/partnered & 572 & 75.5 \\
\hline Divorced/separated & 58 & 7.7 \\
\hline Not married & 80 & 10.6 \\
\hline Widowed & 48 & 6.3 \\
\hline \multicolumn{3}{|l|}{ Family status } \\
\hline Alone & 57 & 7.5 \\
\hline With partner & 231 & 30.5 \\
\hline Partner with children & 349 & 46 \\
\hline Other family & 121 & 16 \\
\hline \multicolumn{3}{|l|}{ Education level } \\
\hline Primary & 415 & 54.7 \\
\hline High school & 295 & 38.9 \\
\hline University & 48 & 6.4 \\
\hline \multicolumn{3}{|l|}{ Employed condition } \\
\hline Labourer & 359 & 47.4 \\
\hline Unskilled worker & 229 & 30.2 \\
\hline Skilled worker & 92 & 12.2 \\
\hline Manager or supervisor & 53 & 7 \\
\hline Self-employed & 24 & 3.2 \\
\hline Family history of cancer & 448 & 59.1 \\
\hline Family dead by cancer & 342 & 45 \\
\hline \multicolumn{3}{|l|}{ Karnofsky index } \\
\hline Normal activity $(100-80)$ & 552 & 72.6 \\
\hline Some symptoms of impairment $(70-50)$ & 208 & 27.4 \\
\hline Tumour site & 168 & 22.1 \\
\hline Breast & 163 & 21.5 \\
\hline Gastrointestinal & 146 & 19.2 \\
\hline Respiratory & 37 & 4.9 \\
\hline Head and neck & 112 & 14.8 \\
\hline Genitourinary & 10 & 1.3 \\
\hline Other solid tumours & 123 & 16.2 \\
\hline \multicolumn{3}{|l|}{ Not solid tumours } \\
\hline \multicolumn{3}{|l|}{ Oncology treatment } \\
\hline Surgery & 426 & 57.4 \\
\hline Adjuvant chemotherapy & 665 & 88.3 \\
\hline Adjuvant radiotherapy & 214 & 33 \\
\hline Hormonal treatment & 57 & 6.7 \\
\hline Other & 74 & 8.9 \\
\hline
\end{tabular}

\section{Psychological distress and social support}

On the HADS scale, the mean score of sample was 9.6 (SD, 6.6). With regard to the overall sample, 189 patients $(24.9 \%)$ were above the 14 cut-off point in HADS used to indicate clinical distress, so it can be suspected they were suffering from $p$ sychiatric disorder. In the sample studied, a total of $578(76 \%)$ patients took part in the psychiatric interview DIS-I. A quarter of all patients $(197,26 \%)$ fulfilled the diagnostic criteria for the existence of psychiatric disorder. The percentage of psychopharmacology treatment in cancer treatment 
was $34 \%$, which is higher than the percentage of patients with psychiatric disorders that was $26 \%$ as stated above. However, from the total number of patients with psychopharmacology treatment, a quarter of patients $(20.7 \%)$ did not have criteria for psychiatric diagnosis. Therefore, a proportion of patients with psychiatric disorders $(12.3 \%)$ did not receive psychopharmacology treatment. Table II shows a description of psychiatric diagnosis.

The median number of close friends or relatives that overall patients reported in their social network was 8 , mean number was 11.6 (SD, 13.8). More than half the patients $(n=479,64.9 \%)$ reported adequate social support all of the time. In functional aspects of social support, the mean level perceived was a high value in Overall Support Index (range 0-95; mean, 79.8; SD, 12.3), quite high in Emotional/Informational support (range 0-60; mean, 52.2; SD, 9.2) and more increased in Instrumental support (range 0-20; mean, 18.2; SD, 2.8) and Affectionate support (range 0-15; mean, 14; SD, 1.8).

\section{Differences on social support perceived considering presence of psychiatric disorder or psychopharmacology treatment}

A multivariate analysis was calculated to identify differences on dimensions of social support perceived (Structural Support, Emotional/Informational, Affectionate, Instrumental, Overall Support Index), between those cancer patients diagnosed with a psychiatric disorder and those who were not diagnosed. Differences on patients who were receiving psychopharmacology treatment versus those who were not were estimated as well on social support dimensions. Significant multivariate effects were obtained in the diagnosis of psychiatric disorder variable (Pillai's trace, $0.03 ; F=4.45 ; p<0.01$; partial eta squared, 0.03 ) and psychopharmacology treatment variable (Pillai's trace, $0.01 ; F=2.35 ; p<0.05$; partial eta squared, 0.01 ). Then univariate analysis showed significant differences

Table II. Psychiatric disorders in cancer outpatients

\begin{tabular}{lrl}
\hline Psychiatric disorders & $n$ & $\%$ \\
\hline Major depressive & 11 & 1.5 \\
Adjustment disorder anxiety & 50 & 6.5 \\
Adjustment disorder depressed mood & 61 & 8 \\
Adjustment disorder mixed symptoms & 29 & 3.8 \\
Anguish disorder with/without agoraphobia & 4 & 0.5 \\
Dysthymia & 13 & 1.7 \\
Generalized anxiety disorder & 2 & 0.3 \\
Pliobia specific & 9 & 1.2 \\
Somatoform disorder & 4 & 0.5 \\
Post-Traumatic Stress disorder & 7 & 1 \\
Others disorders & 7 & 0.9 \\
Psychopharmacology treatment & 259 & 34.4 \\
Psychiatric disorders with psychopharmamiogy treatment & 104 & 13.7 \\
\hline
\end{tabular}

on psychiatric disorder with Emotional/Informational support, Affectionate support and Overall Support Index, as shown in Table III. Meanwhile, psychopharmacology treatment obtained significant differences in structural and all functional dimensions of social support except for Affectionate support.

\section{Discussion}

Cancer is considered a life-threatening process that engenders a state of prolonged stress. On the other hand, social support is a resource that patients receive from family, friends or healthcare professionals to adjust to stressful situations (Helgeson \& McUmber, 2010). The present study investigated structural and functional aspects of social support in different dimensions with two variables, cancer patients with psychiatric diagnosis and cancer patients receiving psychopharmacology treatment. It was shown that the prevalence of psychological distress $(24,9 \%)$ and psychiatric diagnosis $(26 \%)$ in cancer outpatients was consistent with the range of prevalence reported in other studies (Bringmann et al., 2008; Culha et al., 2004; Gil et al., 2008), but it was more than prevalence of psychiatric disorder in the general population, which is around $20 \%$ (Haro et al., 2006).

Table III. Differences of social support perceived in patients diagnosed by psychiatric disorder or patients requirad psychopharmacology treatment

\begin{tabular}{|c|c|c|c|c|}
\hline & Mean & $S D$ & F & $\begin{array}{c}\text { Partial eta } \\
\text { squared }\end{array}$ \\
\hline \multicolumn{5}{|l|}{ Psychiatric disorder } \\
\hline Structural support & 11.88 & 17.12 & 0.55 & 0.001 \\
\hline Emotional/informational & 49.44 & 10.71 & $19.11^{* *}$ & 0.027 \\
\hline Affectionate & 13.56 & 2.27 & $12.30^{* *}$ & 0.018 \\
\hline Instrumental & 17.79 & 3.07 & 4.70 & 0.005 \\
\hline Overall support index & 76.31 & 14.22 & $16.73^{* *}$ & 0.024 \\
\hline \multicolumn{5}{|l|}{ No psychiatric disorder } \\
\hline Structural Support & 11.59 & 12.59 & & \\
\hline Emotional/informational & 53.26 & 8.52 & & \\
\hline Affectionate & 14.17 & 1.72 & & \\
\hline Instrumental & 18.41 & 2.81 & & \\
\hline Overall support index & 81.13 & 11.41 & & \\
\hline \multicolumn{5}{|l|}{ Psychopharmacology treatment } \\
\hline Structural support & 10.35 & 12.48 & $4.32^{*}$ & 0.006 \\
\hline Emotional/informational & 50.86 & 9.34 & $7.87^{* *}$ & 0.011 \\
\hline Affectionate & 13.76 & 2.07 & 3.83 & 0.006 \\
\hline Instrumental & 17.96 & 3.02 & $4.17^{*}$ & 0.006 \\
\hline Overall support index & 78.01 & 12.42 & $7.84^{4 *}$ & 0.011 \\
\hline \multicolumn{5}{|c|}{ No psychopharmacology treatment } \\
\hline Structural support & 12.15 & 13.99 & & \\
\hline Emotional/informational & 52.99 & 9.16 & & \\
\hline Affectionate & 14.14 & 1.79 & & \\
\hline Instrumental & 18.39 & 2.82 & & \\
\hline Overall support index & 80.83 & 12.25 & & \\
\hline
\end{tabular}


The differences of data between psychopharmacology treatment and psychiatric diagnosis highlighted that psychopharmacology treatment could alleviate psychiatric diagnosis, considering that $20.7 \%$ of patients with psychopharmacology treatment did not have psychiatric diagnosis. On the other hand, it was outlined that a proportion of patients with psychiatric diagnosis $(12.3 \%)$ did not have psychopharmacology treatment. When measuring social support perceived by cancer patients, results showed an adequate amount of social support perceived in the global index and in differenced dimensions of social support. Also, the size of a person's social network was similar to other studies (Kornblith et al., 2001).

The results of this study suggested that patients with diagnosis of psychiatric disease showed differences in perception of Emotional/Informational support and Affectionate support received; these differences were not seen in Structural support or Instrumental support. Patients receiving psychopharmacology treatment were more likely to have higher levels of social support received, except on Affectionate support. Considering that Affectionate support was found to be a significant predictor of psychological distress, that is, in the absence of an intimate relationship, patients might have been less able to have meaningful reassurance from someone that they felt cared deeply about them (Kornblith et al., 2001)

Findings in other research showed a significant but negative relation between Instrumental support and physical well-being, with symptom distress negatively related to physical well-being (Bloom, Stewart, Johston, Banks, \& Fobair, 2001; Talley et al., 2010). In the current study, an explanation about Instrumental support could not be related with psychological distress because patients may have an adequate health-related quality of life despite following oncology treatment.

The result highlighted the difference on Emotional/ Informational support in patients with psychiatric disorder or undergoing psychopharmacology treatment, indicating that patients with poorer mental health were more likely to report lower social support perceived (Bloom et al., 2001; Helgeson et al., 2004). Also, the importance of treatment of psychiatric co-morbidity in cancer patients was emphasized because of its influence on the perceived social support and other mediating factors on enhancing coping processes. In other studies, healthcare professionals were identified as sources strongly linked to Emotional/Informational support (Akechi et al., 1998). Access to accurate health information about their disease, treatment, side effects and prognosis can be a valuable resource to enhance psychological adjustment in cancer patients (Parker et al., 2003). Healthcare professionals have the opportunity to normalize the concerns and symptoms of cancer patients; therefore, considering the value of information as a resource in the cancer setting, this may be moderated by the individual's information preferences and may indeed help them cope better with cancer.

This study has some limitations that must be acknowledged. Firstly, the sample was taken from patients enrolled in only one hospital. This reduces the possibilities to make generalizations. Secondly, for future studies, it would prove interesting to explore longitudinal assessment. As this is a cross-sectional study, information about pre-treatment or post-treatment psychological adjustment and social support is missing to specifically determine the adequate perceived need for social support over time. Moreover, cross-sectional design could diminish diagnosis rates of psychiatric disorders, considering that its assessment was done at one point in time during the course of cancer. Thirdly, patient's sociodemographic and clinical variables were not analysed; these could have an effect on psychological distress variations and social support perceived. Finally, this study suggests a positive benefit from psychopharmacology treatment on Affectionate support perceived; nevertheless, the results need to be interpreted cautiously due to cross-sectional design of the study or the lack of a control group.

Although there are limitations to this study, these findings could suggest important implications in clinical practice. Healthcare professionals may promote interventions such as counselling and use of support groups to help increase patients' emotional support.

\section{Conflict of interest}

No conflict of interest declared.

\section{Acknowledgments}

This research was supported by the Catalan Agency for Health Technology Assessment and Research (No. 102/ 19/2004). We express our gratitude to those cancer patients who kindly volunteered to participle in this study.

\section{REFERENCES}

Akechi, T., Okemuxa, H., Yamawaki, S, \& Uchitumi, Y 1998). Predictors of patients inental adjustment to cancer: Patent characteristics and social suppor British Jouanal of Cancer, 77, 2381-2385.

Bloom, I. R., Stewart, S. L., Johston, M., Banks, P.

8. Pobar, P. (2001). Sources of support and the physical and mental well-being of young women with breast cancer. Suctal Saence of Medreme, 53 , 1513-1524

Bringmann, H., Singer, S., Höcked, M., Stolzenburg, I. U. Krauß, O., \& Schwarz, R. (2008). Laag-term course of psychiatric disorders in cancer patients: A pilot study. GMS Psychosoctal Medictine, 5, Doc 03 .

Costa-Requena, G., Salamero, M., \& Gil, F. (2007),

Validación del cuestionario MOSSSS de apoyo social en pacientes con cáncer. Medrena Canzea (Barcelona), 128, 687-691.

Culha, F., Baltalarh, B., Kallkan, N., Karadag, F., Ozdel O., \& Karagoz, N. (2004). Pyychuntric morbidity among cancer patients and awareness of illness Supportive Care in Cancer, 12, 161-167.

Devine, D., Parker, P. A., Fouladi, R. T., \& Colien, 1 (2003). The association between social support intrusive thoughits, avoidance, and adjustnent 
following an experimental cancer treatment. Psycho Oncology, 12, 453-462.

Gi, F., Costa-Requena, G., Pérez, F. I., Salanero, M. Sánchez, N., \& Sirgo, A. (2008). Adaptación psicolo. gica y prevalencia de trastornos mentales en pacientes con cincer. Medicina Clinica (Barcelona), 130, 90-92 Haro, J. M., Falacin, C., V.lagut, G., Martinez, M., Bernad, M., Laque, 1. ....,Grapo ESFMeD- Espana. (2006). Pre valencia de los trastornos mentales y factores asocidos Resultados del estuio ESFMeD- Espona. Merdicania Cimca (Barciona), 126, 445-451.

Helgeson, V. S., \& McUmber, A. L. (2010). Socal environment and canner. In J.C. Holland (ed.), Psycho Oncology, 2ad edn, Oxford Unversity Press, New York Helgeson, V. S., Snyder, P., \& Seltman, H. (2004) Prychological and physical adjustment to breast cancer over 4 years: identifyng distunct trajectories of change. Health Psychology, 21, 3-15.

Karnofshy, D. A., Albelman, W. H., Craver, L F., \& Burchenal, I. H. (1948). The use of nitragen mustard in the palliative treatment of carcinoma. Cancer, 1 639-656.
Kissane, D. W., Grabsch, B., Love, A., Garke, D. M. Bloch. S., \& Smith. G. C. (2004). Psychiatric disorder in women with carly stage and advanced breast cancer: A comparative analysic. The Auctralian and New Zealand joornal of Psychatry, 38, 320-326. Kornblith, A. B., Herndon, J. F, Zuckerman, E, Viscoli. C. M. Horwitz, R. 1., Cooper, M. R. .... Holland, J. C. (2001). Social support as a buffer to the pychiological impact of stressfal life events in women with breast cancer. Cencer, $91,443-454$.

Kroenke, C. H., Kubzansky, L, D., Schernhammer, B, S.. Holmes, M. D. \& Kawach, 1. (2006), Social networks, social support, and survival after breast cancer diagnosis. journal of Chmcal Oncology, 24, 1105-1111.

Pakker, P. A., Baile, W. F., Moor, C, \& Cohen, L (2003). Psychosocial and demographic predictors of quality of life in a large sample of cancer patients. Psycho-Oncology, 12, 183-193.

Quntana, I. M., Padierna, A, Esteban, C., Arostegui, 1. Blbas, A, \& Ruiz, L. (2003). Evaluation of the prychometric characteristics of the Spanish versioa of the Hospital Anxiely and Depression Scale. Acta Psychatrea Scandenanca, 107, 216-221.

Rezavt, D., Delvaux, N., Farvacques, C., \& Robaye, E. (1990). Screening for adjustment disorders and majo depressive dusorders un cancer in-patients. The Brrnsh Joumal of Psychias y, 156, 79-83.

Sherboume, C. D., \& Stewart, A. L (1991). The MO social suport survey. Sorzal Science of Mederne, 32 , 705-714.

Spriter, R. L. (1983). Structured Chrical tnatrvinu for DSM-IIJ-R. New York State Institute. New York.

Talley, A., Molix, L., Schleggd, R. I. \& Bettencourt, A. (2010). The influence of breast cancer sarvivorg Perceaved partaer socal support and need satisfaction on depressive symptoms: A longitudinal analysis. Psychology o Healsh, 25, 433-449.

Zobora, J., Bnntzenhofeszoc, K, Curbow, B., Hooker, C. \& Paantadosi, S. (2001). The prevalence of psycholongal distress by cancer site. Psycho Oncology, 10, 19-28.

Zagmond, A. S., \& Snath, R. P. (1983). The Hospital Anxiety and Depression Scale. Acai Psychatarica Scandenavica, 67, 361-70 
Articulo 3

Costa-Requena G, Ballester Arnal R, Gil F. A 1-Year follow-up of podttraumatic Stress Disorder (PTSD) Symptoms and Perceived Social Support in Cancer. Psycho-Oncologie 2014; 8: 89-93. 


\title{
A One-Year Follow-up of Post-Traumatic Stress Disorder (PTSD) Symptoms and Perceived Social Support in Cancer
}

\author{
Un suivi d'un an des symptômes du syndrome de stress post-traumatique (SSPT) \\ et de la perception du soutien social chez les patients atteints d'un cancer
}

\section{G. Costa-Requena · R. Ballester-Arnal · A. Qureshi · F. Gil}

Received: 19 November 2013; Accepted: 10 May 2014

(C) Springer-Verlag France 2014

\begin{abstract}
Aims: Diagnosis of post-traumatic stress disorder (PTSD) symptoms in cancer patients fluctuates over the course of cancer according to the timing of assessment. In this longitudinal study, the prevalence of PTSD symptoms and the association between PTSD symptoms and the buffering variable of perceived social support were examined at one year follow-up.

Procedure: People with different types of cancer were assessed (breast cancer, head and neck cancer, and colorectal tumor) on four occasions: pre-treatment, at the end of cancer treatment, at six months post-treatment, and at one year posttreatment. Multivariate analyses were used to assess associations of perceived social support in patients with PTSD symptoms at the aforementioned four time points.

Results: No significant differences in perceived social support were found at the various follow-up times. However, diagnosis of PTSD symptoms showed differences based on the time of assessment $(F=5.50, p=0.02)$. At pre- and post-treatment, social support was negatively related to re-experiencing $(p<0.00)$ and numbing $(p<0.00)$ PTSD symptoms. At six months post-treatment, social support was negatively related to all symptoms of $\operatorname{PTSD}(p<$ 0.00 ). Finally, at one year post-treatment, perceived social
\end{abstract}

G. Costa-Requena (区) A A. Qureshi

Department of Psychiatry,

Hospital Universitari Vall d'Hebron, CIBERSAM,

Universitat Autònoma de Barcelona, Barcelona, Spain

e-mail : gcosta@vhebron.net

R. Ballester-Arnal

Department of Basic Psychology,

Clinical psychology and Psychobiology,

Jaume I University, Castellon, Spain

F. Gil

Psycho-oncology Unit, Duran i Reynals Hospital,

Barcelona, Spain support was negatively related only to numbing symptoms $(p<0.00)$ of PTSD.

Conclusion: Over the course of cancer, buffering effect of perceived social support had a specific influence on PTSD symptoms.

Keywords Post-traumatic stress disorder - Cancer - Social support

Résumé Objectifs : Le diagnostic des symptômes de syndrome de stress post-traumatique (SSPT) chez les patients atteints d'un cancer varie au fil de la maladie, en fonction du moment de l'évaluation. Dans cette étude longitudinale, la prévalence des symptômes de SSPT et le lien entre ces symptômes de SSPT et la variable tampon du soutien social perçu ont fait l'objet d'un examen sur un suivi d'une année.

Mode opératoire: Des personnes atteintes de divers types de cancer ont été évaluées (cancer du sein, tumeur au cerveau et à la gorge et colorectale) à quatre moments : en prétraitement, à la fin du traitement contre le cancer, à six mois de posttraitement et un an après le posttraitement. Des analyses multidimensionnelles ont évalué les liens avec la perception du soutien social chez les patients souffrant de symptômes de SSPT aux quatre moments précités.

Résultats : Aucune différence significative dans la perception du soutien social n'a été constatée aux divers moments du suivi. Toutefois, le diagnostic des symptômes de SSPT a montré des écarts fondés sur le moment de l'évaluation $(F=5,50, p=0,02)$. Lors du pré- et du posttraitement, le soutien social a été négativement associé au fait de revivre l'expérience $(p<0,00)$ et à des symptômes de SSPT de repli sur soi $(p<0,00)$. A six mois de postraitement, le soutien social a été négativement associé à l'ensemble des symptômes de SSPT $(p<0,00)$. Enfin, à un an de posttraitement, le soutien social perçu a été négativement associé aux symptômes de SSPT de repli sur soi $(p<0,00)$. 
Conclusion : Au fil du cancer, l'effet tampon du soutien social perçu a eu une influence spécifique sur les symptômes de SSPT

Mots clés Syndrome de stress post-traumatique $\cdot$ Cancer . Soutien social

\section{Introduction}

Longitudinal research indicates that PTSD symptoms in patients with cancer fluctuate subjectively over time. The prevalence rates for a lifetime cancer-related PTSD diagnosis varies from $4 \%$ to $17 \%$, depending on when the assessment is carried out. Previous research has predominantly focused on breast cancer patients and prostate cancer patients, and has shown evidence that the prevalence of PTSD symptoms declines following treatment completion as a result of their interaction with significant predictors of psychological comorbidity, such as perceived positive social support or detrimental subjective threat of cancer [1-4].

Several studies have shown how the influence of higher levels of perceived social support can influence the reduction of psychological distress and improve the quality of life in cancer patients, even at two-year follow-up $[5,6]$. Poor social support has been found to be a significant predictor of the occurrence of psychological co-morbidity, specifically PTSD symptoms, in cancer patients [7]. In particular, for head and neck cancer patients, adequate levels of pretreatment social support predicted favorable mental health one year after the diagnosis [8]. In this line, the stressbuffering model holds that perceived social support protects patients from the potentially pathogenic influence of stressful events as it facilitated coping and adjustment responses to cancer. In prostate cancer, research has demonstrated that higher levels of perceived social support are a protective factor for health-related quality of life (HRQoL) [6]. Perceived social support serves as a buffer by facilitating coping with the adverse effects of multiple stressful situations over the course of the illness. Other studies have found that perceived social support predicted better mental functioning in cancer patients by facilitating cognitive processing, which can potentially lead to improvements in HRQoL [9].

The purpose of this study was, first, to assess longitudinally the prevalence and course of PTSD symptoms prior to and after treatment in cancer patients, and secondly, to explore the relationship between PTSD symptoms and perceived social support during the first year after completion of cancer treatment. In this second objective, it was hypothesized that perceived social support would differentially contribute to alleviate each of the described PTSD symptoms at four follow-up points; considering that psy- chological distress, physical symptoms, side effects of treatment, or patient's functional status could be alleviated in post-treatment follow-up time.

\section{Materials and methods}

The study was carried out in a cancer hospital. The inclusion criteria were outpatients with a verified new cancer diagnosis, between 18 and 80 years of age, and who are able to understand the study and read the scales. Patients with a low activity and high medical needs status (Karnofsky < $40 \%$ ), or significant cognitive impairment were excluded. The study was approved by the Institutional Review Board and the Ethics Committee.

Participants were consecutively recruited from functional units that specialized in the treatment of breast cancer, head and neck cancer, and colorectal tumors. All patients were informed of the objective of this study when they signed the consent form before they were asked to complete the questionnaire. Preliminary to oncology treatment (T1), the patients were assessed for socio-demographic information, and then completed the PTSD Checklist-Civilian Version (PCL-C) and Medical Outcomes Study-Social Support Survey (MOSSSS). Subsequent assessments were carried out at the end of the treatment (T2), at six months post-treatment (T3), and one year post-treatment for each type of tumor (T4).

A chart review was carried out to determine the patient's clinical and functional status. The presence of PTSD symptoms was assessed with the PCL-C. This is a 17-item, selfrating, screening tool using a 5-point Likert-type scale ranging from 1 (not at all) to 5 (extremely) for each item. The PCL-C provides a continuous score based on the number and severity of PTSD symptoms according to DSM-IV criteria. The questionnaire yields a total score, as well as PCL-C's dimensions. The Spanish version of the PCL-C total score showed an acceptable reliability of $\alpha=0.90$, with a threefactor solution consisting of Hyperarousal/Re-experiencing $\pm \alpha=0.87$, Numbing $\pm \alpha=0.78$, and Avoidance $\pm \alpha=0.69$ [10]. PTSD diagnosis was determined using the cut-off score method, with the recommended score for cancer patients being 44 [1].

Social support was assessed with the MOS-SSS. This questionnaire measures functional aspects of the perceived availability of social support. For each item, the respondent was asked to indicate how often each support was available to them if needed. Items are scored on a 5-point Likert scale ranging from 1 (none of the time) to 5 (all of the time). For the total score algebraic sums were computed, with a higher score indicating a better perception of social support. Adequate psychometric properties of MOS-SSS have been established in the Spanish version, with a Cronbach's alpha of 0.94 [11].

\section{$\underline{\text { Springer }}$}


Descriptive statistics were carried out at the four different times to describe the response range on the PCL-C and MOS-SSS in cancer patients. Repeated measures were calculated to compare differences across total PCL-C scores over time. Correlation analyses were conducted between socio-demographic variables and site of tumor with PTSD symptoms and MOS-SSS. Those variables with a significant trend were included as controls. Multivariate analyses were used to assess associations of perceived social support with PTSD symptoms at the four time points. An estimate of effect size was calculated using partial Eta-squared. Analyses were carried out using the Statistical Package for Social Sciences (SPSS version 15.0).

\section{Results}

Sixty-seven patients participated in the study. Of these, 55 patients completed the assessment at the end of the treatment, 50 completed the assessment at six months posttreatment, and 40 completed the assessment at one-year follow-up. Participants did not complete the study due to disinterest (13 participants), not localizable $(N=7)$, indisposition $(N-4)$, and death $(N-3)$. At the initial assessment, $42(62.7 \%)$ of the participants were female, and the median age was 52 years. The sample consisted mostly of breast cancer $(53.7 \%)$ patients. A total of 57 patients $(85.1 \%)$ were either married or partnered. The majority of the patients had undergone radical surgery $(77.61 \%)$, with additional oncology treatment. A summary of the medical and socio-demographic characteristics can be found in Table 1.

\section{Co-morbidity of PTSD symptoms and perceived social support}

Using repeated measures of the general lineal model $(F=$ $0.00, p=0.92$ ), no differences were found between the MOS-SSS total scores at the initial and final assessments; means are shown in Table 2. PCL-C total scores showed differences over the different evaluation times $(F=5.50, p=$ 0.02 ); means of PCL-C total scores at different times are presented in Table 2. On the basis of the recommended cut-off score (PCL-C total score $>44$ ) for cancer patients, at pre-treatment $9 \%$ of the sample was identified as likely to have significant PTSD symptoms, which increased to $12.7 \%$ at post-treatment and decreased to $10 \%$ of patients at six months and one-year follow-up post-treatment. Differences were not found between initial and follow-up times for each tumor site with regards to PCL-C total score or in perceived social support for each tumor site over time. These results are listed in Table 2.

\begin{tabular}{|c|c|c|}
\hline Age & \multicolumn{2}{|c|}{$52.3(10.64)$} \\
\hline Mean (SD) & \multicolumn{2}{|c|}{52} \\
\hline Median & \multicolumn{2}{|c|}{2969} \\
\hline \multicolumn{3}{|l|}{ Range } \\
\hline & $N$ & $\%$ \\
\hline Sex & 42 & 62.7 \\
\hline \multicolumn{3}{|l|}{ Female } \\
\hline Marital status & 57 & 85.1 \\
\hline Married / partnered & 5 & 7.5 \\
\hline Divorced / separated & 4 & 6 \\
\hline Single & 1 & 1.5 \\
\hline \multicolumn{3}{|l|}{ Widowed } \\
\hline Education level & 50 & 74.6 \\
\hline Primary & 12 & 17.9 \\
\hline High school & 5 & 7.5 \\
\hline \multicolumn{3}{|l|}{ University } \\
\hline Tumor site & 36 & 53.7 \\
\hline Breast & 14 & 20.9 \\
\hline Colorectal & 17 & 25.4 \\
\hline \multicolumn{3}{|l|}{ Head and neck } \\
\hline Type of Treatment & 52 & 77.61 \\
\hline Surgery & 42 & 62.68 \\
\hline Radiation & 40 & 59.70 \\
\hline Chemotherapy & 26 & 38.80 \\
\hline Hormonal & & \\
\hline
\end{tabular}

\section{Relationship between perceived social support and PTSD symptoms after cancer treatment}

Spearman's tho correlation was calculated between PTSD symptoms and MOS-SSS total score, with age, gender, education status, and site of tumor, which yielded no significant associations. Multivariate analyses were carried out in order to ascertain the relationship between perceived social support and PTSD symptoms at the four time points. At pretreatment and post-treatment, social support was negatively related to re-experiencing $(p<0.00)$ and numbing $(p<0.00)$ symptoms of PTSD. At six months post-treatment, perceived social support was negatively related to all symptoms of PTSD $(p<0.00)$. Finally, at one year post-treatment, perceived social support was related only negatively to numbing symptoms $(p<0.00)$ of PTSD, as are shown in Table 3 .

\section{Discussion}

This was a prospective study that examined the relationship between perceived social support and the course of PTSD symptoms after cancer treatment. Over the course of cancer, 
because many intrusions are future-oriented fears about one's health following treatment completion [14]. Furthermore, several studies have found that cognitive processing about the subjective threat of cancer through social interactions mediated the relationship with psychological adjustment after cancer treatment [3]. Similarly, this study found that perceived social support was negatively related to numbing symptoms of PTSD (or restricted affective expression) at all follow-up times: prior to cancer treatment, at post-treatment, at six months, and one year post-treatment. Therefore, over the course of cancer, consistent with previous research, interventions with supportive group therapy specifically aimed to bolster the ability to cope with emotional aspects of cancer and helped to reduce symptoms of PTSD and psychological distress [4].

Several limitations of this study should be considered. First, the small sample size and its heterogeneity decrease the generalization of the findings. The inclusion of a greater number of participants could show variations between the different cancer sites in relation to PTSD symptoms and perceived social support. The second limitation was the statistical analysis. Multivariate analyses did not obtain information about the causal association between social support and PTSD symptoms. Finally, the relationships between social support and psychological distress examined in this study may be influenced by factors that were not included in the study. In future research, it would be worthwhile to examine the role of clinical variables, such as specific side effects, toxicity of treatment, gender, education level, or previous psychological disorder. These factors could increase vulnerability to developing PTSD symptoms after cancer treatment [14]. Furthermore, considering the stress-buffering model for future studies, HRQoL as an outcome variable could be included to assess the influence of perceived social support or cognitive functioning on global patients' well-being.

Despite these limitations, this study represents a step toward understanding the association between PTSD symptoms and perceived social support in cancer patients. Specifically, the findings highlight that buffering variable of perceived social support was differentially related to alleviating symptoms of PTSD over the course of cancer treatment and at follow-up. As such, patients may need different types of psychosocial support in accordance with the time elapsed following cancer treatment.

Acknowledgements This research was supported by the Catalan Agency for Health Technology Assessment and Research (No. 102/19/2004). We express our gratitude to those cancer patients who kindly volunteered to participle in this study. The authors would like to thank Jenny McCosby for her help in editing the manuscript. Part of this research was presented at the 15 th world congress of
International Psycho-Oncology Society, Rotterdam, November 2013 .

Conflict of interest: The authors don't have any conflict of interest to declare.

\section{References}

1. Andrykowski MA, Cordova MJ, Studts JL, Miller TW (1998) Posttraumatic stress disorder after treatment for breast cancer: Prevalence of diagnosis and use of the PTSD Checklist-Civilian Version (PCLC) as a screening instrument. J Consul Clin Psychol 66:586 90

2. Andrykowski MA, Cordova MJ, McGrath PC, et al (2000) Stability and change in posttraumatic stress disorder symptoms following breast cancer treatment: A 1-year follow-up. PsychoOncol 9:69-78

3. Mehnert A, Lehmann C, Graefen M, et al (2010) Depression, anxiety, post-traumatic stress disorder and health-related quality of life and its association with social support in ambulatory prostate cancer patients. Eur J Cancer Care 19: 736-45

4. Levine EG, Eckhardt J, Targ E (2005) Change in post-traumatic stress symptoms following psychosocial treatment for breast cancer. Psycho-Oncol 14:618-35

5. Eom C-S, Shin DW, Kim SY, et al (2013) Impact of perceived social support on the mental health and health-related quality of life in cancer patients: Results from a nationwide, multicenter survey in South Korea. Psycho-Oncol 22(6):1283-90. DOI: $10.1002 /$ pon 3133

6. Zhou ES, Penedo FJ, Lewis JE, et al (2010) Perceived stress mediates the effects of social support on health-related quality of life among men treated for localized prostate cancer. J Psychosom Res 69:587-90

7. Mehnert A, Koch U (2008) Psychological comorbidity and health-related quality of life and its association with awareness, utilization, and need for psychosocial support in a cancer register-based sample of long-term breast cancer survivors. J Psychosom Res 64:383-91

8. Howren MB, Christensen AJ, Kamell LH, et al (2013) Influence of pre-treatment social support on health-related quality of life in head and neck cancer survivors: Results from a prospective study. Head Neck 35(6):779-87. DOI: 10.1002/hed.23029

9. Roberts KJ, Lepore SJ, Helgeson V (2006) Social-cognitive correlates of adjustment to prostate cancer. Psycho-Oncol 15:183-92

10. Costa-Requena G, Gil F (2010) Posttraumatic stress disorder symptoms in cancer: psychometric analysis of the Spanish Posttranmatic Stress Disorder Checklist-Civilian version. Psycho-Oncol 19 500-7. DOI: $10.1002 /$ pon. 1601

11. Costa-Requena G, Salamero M, Gil F (2007) Validación del cuestionario MOS-SSS de apoyo social en pacientes con cáncer (Validity of the questionnaire MOS-SSS of social support in cancer patients). Med Clin (Barc) 128:687-91

12. De Leeuw JRJ, de Graeff A, Ros WJG, et al (2000) Negative and positive influences of social support on depression in patients with head and neck cáncer: A prospective study. Psycho-Oncol 9:20-8

13. Gómez L, Abrams MP, López-Martínez AE, Asmundson GJG (2012) Trauma exposure and health: The role of depressive and hyperarousal symptoms. J Traum Stress 25:641-8

14. Kangas M, Henry JL, Bryant RA (2002) Posttraumatic stress disorder following cancer. A conceptual and empirical review. Clin Psychol Review 22:499-524 
